\title{
URBAN AND PLACE-BASED ENVIRONMENTAL EDUCATION IN THE ONTARIO SECONDARY SCHOOL CURRICULUM
}

by

\author{
Laila Mnyusiwalla \\ B.A.Sc. - Chemical Engineering 2004, University of Toronto \\ B.Ed. - Intermediate/Senior 2005, University of Toronto
}

A thesis presented to Ryerson University

in partial fulfillment of the

requirements for the degree of

Master of Applied Science

in the Program of

Environmental Applied Science and Management

Toronto, Ontario, Canada, 2016

(c) Laila Mnyusiwalla 2016 


\section{Declaration}

I hereby declare that I am the sole author of this thesis. This is a true copy of the thesis, including any required final revisions, as accepted by my examiners.

I authorize Ryerson University to lend this thesis to other institutions or individuals for the purpose of scholarly research

I further authorize Ryerson University to reproduce this thesis by photocopying or by other means, in total or in part, at the request of other institutions or individuals for the purpose of scholarly research.

I understand that my thesis may be made electronically available to the public. 


\begin{abstract}
Urban and Place-based Environmental Education in the Ontario Secondary School Curriculum

By Laila Mnyusiwalla

Environmental Applied Science and Management Program, Ryerson University Master of Applied Science, 2016
\end{abstract}

This study reviews the Ontario secondary school curriculum in light of recommendations made by the 2007 Bondar Report, "Shaping Our Schools, Shaping Our Future". It analyzes curriculum expectations and enrollment data for the purpose of reporting upon and providing recommendations for urban and place-based environmental education (U\&PBEE). The extent and prescriptiveness of U\&PBEE coverage by subject, course, grade, and course progression or pathway are reported upon. These findings are contextualized through the perspectives of diverse stakeholder groups at the "Education Experts' Workshop: Implementing 2007 Bondar Report's Intended Outcomes in 2015" hosted by Ryerson University in April 2015. EE in Ontario does not have its own discrete compulsory courses and despite having been "embedded" in the curriculum, the important arenas of U\&PBEE are being applied inconsistently across the mandatory curriculum. Poor enrolment in senior electives shows that the focus of students remains elsewhere, fracturing EE's progression in secondary schools. 


\section{Acknowledgements}

I would like to thank my supervisor, Dr. Michal Bardecki for guiding me through this daunting task. It was a difficult process but a great learning experience. I would also like to thank Dr. Lynda McCarthy for providing me with the opportunities that I needed to deepen my understanding of EE in Ontario. 


\section{TABLE OF CONTENTS}

Author's Declaration

Abstract iil

Acknowledgements iv

List of Tables vii

List of Figures viii

List of Appendices $\quad$ ix

List of Abbreviations $\quad \mathrm{x}$

1. INTRODUCTION 1

1.1 The Importance of Environmental Education 1

1.2 Defining Key Terms 2

1.2.1 Environmental Education 2

1.2.2 Place-Based Environmental Education 2

1.2.3 Urban Environmental Education 4

1.3 Thesis Objectives 6

2. LITERATURE REVIEW 8

2.1 Context for EE $\quad 8$

2.1.1 Environmental Education 8

$\begin{array}{ll}2.1 .2 \text { Assessment of Environmental Literacy } & 11\end{array}$

$\begin{array}{lll}2.1 .3 & \text { Approaches to Environmental Education } & 13\end{array}$

\begin{tabular}{lll}
\hline 2.1 .4 & Field Study and Place-Based EE & 14
\end{tabular}

2.1.5 Urban Environmental Education 17

2.2 The Ontario Curriculum and EE Policy 20

2.2.1 Curriculum Policy Documents 21

$\begin{array}{ll}2.2 .2 \text { History of EE in Ontario - Past to Present } & 23\end{array}$

2.2.3 Barriers to the Implementation of EE in Ontario 29

$\begin{array}{ll}2.3 \text { Conclusions } & 32\end{array}$

3. METHOD 33

3.1 Education Experts' Workshop: Implementing 2007 Bondar Report's 33

Intended Outcomes in 2015

\begin{tabular}{ll}
\hline 3.2 Curriculum Review & 35 \\
\hline 3.2 .1 Selection of Courses for Curriculum Review & 35 \\
\hline 3.2 .2 Approach to Curriculum Review & 40
\end{tabular}


3.2.3.1 Identify Curriculum Expectations Related with Place-Based and/or

Urban EE Content

3.2.3.2 Identify Curriculum Expectations Related to Place-Based EE 43

3.2.3.3 Identify Curriculum Expectations Related to Urban EE 46

\begin{tabular}{lll}
\hline 3.2.3.4 Requirement of Field Study/Outdoor Education & 48
\end{tabular}

3.2.3.5 Identify Curriculum Expectations that are Participatory with Action 49 Outcomes

3.3 Enrolment in EE Elective Courses and Course Offering 49

4. ANALYSIS AND DISCUSSION 51

4.1 Summary of Observations from the Education Experts' Workshop: 51 Implementing 2007 Bondar Report's Intended Outcomes in 2015

\begin{tabular}{ll}
\hline 4.1 .1 Policy Awareness and Shared Vision & 51 \\
\hline 4.1 .2 Barriers to the Implementation of EE & 53 \\
\hline 4.1 .3 Outdoor Education & 56 \\
\hline 4.1 .4 Other Concerns & 57 \\
\hline 4.2 Curriculum Review & 58 \\
\hline 4.2 .1 Urban and/or Place-Based EE Content by Theme & 63 \\
\hline 4.2 .2 Urban EE Content Summary & 66 \\
\hline 4.2 .3 Place-Based EE Content Summary & 69 \\
\hline 4.2 .4 Involving Field Study and Action Outcomes & 71 \\
\hline 4.3 Enrolment in EE Elective Courses and Course Availability & 72 \\
\hline 4.3 .1 Grade 9 and 10 Electives & 74 \\
\hline 4.3 .2 Grade 11 Electives & 77 \\
\hline 4.3 .3 Grade 12 Electives & 81 \\
\hline 5. CONCLUSIONS & 86 \\
\hline Appendix A - Main Data Set & 119 \\
\hline Appendix B1 - EEW Invitation & 120 \\
\hline Appendix B2 - EEW Participants List & 121 \\
\hline Appendix B3 - EEW Draft Agenda & 122 \\
\hline References & 58 \\
\hline
\end{tabular}




\section{List of Tables}

Table 1: Formative Experiences of Environmental Educators Contributing to

Personal Concern for the Environment $-\mathrm{N}=232$ (Palmer, 1993)

Table 2: O.S.S.D. Requirements (OME, 2014) 36

Table 3: Description of Course Types (OME, 2014) 38

Table 4: Mandatory Courses Identified For Curriculum Review 39

Table 5: Themes in Urban and Place-based EE 43

Table 6: Place-Based EE Classification, Rationale, and Examples 45

Table 7: Urban EE Classification, Rationale, and Examples 48

Table 8: Urban and/or Place-based EE Content by Course 59

Table 9: Urban and/or Place-based EE Content by Grade $\quad 60$

Table 10: Urban and/or Place-based EE Content by Theme 61

Table 11: Urban and/or Place-based EE Content by Course Type 63

Table 12: Direct Urban EE Content Summary $\quad 64$

Table 13: Indirect Urban EE Content Summary $\quad 65$

Table 14: Direct Place-Based EE Content Summary 67

Table 15: Indirect Place-Based EE Content Summary 68

Table 16: Field Study and Action Outcome Content Summary 70

Table 17: Secondary Enrolment 2012-2013 (OnSIS, 2013) 71

Table 18: Grade 9 and 10 Elective Courses with Urban and/or Place-Based 72

EE Content

Table 19: Grade 9 and 10 Course Availability and Enrolment 73

Table 20: Grade 11 Elective Courses with Urban and/or Place-Based EE $\quad 75$

Content

Table 21: Grade 11 Course Availability and Enrolment 76

Table 22: Grade 12 Elective Courses with Urban and/or Place-Based EE $\quad 78$

Content

Table 23: Grade 12 Course Availability and Enrolment 


\section{List of Figures}

Figure 1: Proportion of the Population Living in Rural Areas, Canada, 1851 to 2011 (Statistics Canada, 2011)

Figure 2: Realms of Urban and Place-Based EE $\quad 5$

Figure 3: Curriculum Structure (OME, 2014) 22

Figure 4: Course Pathways 39

Figure 5: Place-Based EE Categorization Process 44

Figure 6: Urban EE Categorization Process 47 


\section{List of Appendices}

Appendix A: Main Data Set 86

\begin{tabular}{lc}
\hline Appendix B1: EEW Invitation & 119
\end{tabular}

\begin{tabular}{lr}
\hline Appendix B2: EEW Participants List & 120
\end{tabular}

Appendix B3: EEW Draft Agenda 121 


\section{List of Abbreviations}

COEO Council of Outdoor Educators of Ontario

DEEPER Deepening Environmental Education in Pre-Service Education Resource

EE Environmental Education

EEW Education Experts' Workshop

EEON Environmental Education Ontario

GGH Greater Golden Horseshoe

OISE Ontario Institute for Studies in Education

OME Ontario Ministry of Education

OnSIS Ontario School Information System

OSEE Ontario Society for Environmental Education

OSSD Ontario Secondary School Diploma

PD Professional Development

PLC Professional Learning Committees

RUW Ryerson Urban Water

SHSM Specialist High Skills Major

TDSB Toronto District School Board

U\&PBEE Urban and Place-Based Environmental Education 


\section{INTRODUCTION}

\subsection{The Importance of Environmental Education}

Promoting environmental literacy and engagement in youth is of utmost importance in our current climate of rapid growth and change. The continued depletion of natural resources, increased severity of pollution of the land, air and water, and anthropogenic climate change are dire concerns that demand our attention. Moreover, environmental systems and our relationship to them have become increasingly more complex highlighting the need for educated, involved and empowered citizens.

Promoting good citizenship is, in fact, one of the main purposes of publicly funded secondary schools (Reimers, 2006). In the global age, the goals of citizenship extend beyond individual goals of productivity and success. They include preparing students to address political conflict and environmental challenges. Reimer (2006) warns that problems arise when education is poorly coupled with larger societal goals and turns its gaze inward. Preparing students for self-referenced goals, the next level of schooling, future employment, and teaching content without context are examples of secondary schooling with too narrow a focus.

Canada is the second largest country in the world. It is a land "rich in fresh water, maritime access, forests, and mineral resources" and despite having a very small proportion of the world's population, "it has a potentially large role to play in creating solutions to the planet's urgent ecological problems" (Doyle \& MacGregor, 2013). According to Statistics Canada (2011), Ontarians account for nearly $40 \%$ of all Canadians, making Ontario central to Canada's environmental policy and practice.

Catalysts for environmental change in Ontario and a critical mass to enact it are needed more than ever. Secondary schools play a significant role in preparing citizens to shape the future of their communities, regions and planet. They must continue to reflect on their role and evolve to meet the needs of a changing world. 


\subsection{Defining Key Terms}

\subsubsection{Environmental Education (EE)}

There are three components to education in the province of Ontario; policy, curriculum, and practice. The purpose of this study is to examine various aspects of EE curriculum in secondary schools; more specifically, their coverage of place-based and urban themes. Curriculum documents were selected as the basis of this study because they are the primary means in which policy is made into practice. They also provide clear expectations regarding the coverage of specific EE topics, and skills. The document that guides current EE policy in Ontario is titled, Shaping Our Schools, Shaping Our Future: Environmental Education in Ontario Schools (2007), and it defines EE as:

Education about the environment, for the environment, and in the environment that promotes an understanding of, rich and active experience in, and an appreciation for the dynamic interactions of:

1) the earth's physical and biological systems,

2) the dependency of our social and economic systems on these natural systems,

3) the scientific and human dimensions of environmental issues,

4) the positive and negative consequences, both intended and unintended, of the interactions between human-created and natural systems. (OME, 2007b)

Within the field of EE, there are a number of themes and subtopics. This study chose to examine curriculum related to place-based EE, because it plays an important role in connecting students to their surroundings, and urban EE, because it reflects the imminent and complex problems humans will face as the Earth's population increases.

\subsubsection{Place-Based Environmental Education}

Rooting environmental education in one's own community and outdoor environment is a growing trend in the conceptualization of EE. Often referred to as "place-based" environmental education, this type of EE fosters student 
engagement and connection to their immediate environment, grassroots innovation, and environmental stewardship. A study conducted by Puk and Behm in 2003 assessed the inclusion of outdoor education in Ontario secondary schools. This study disseminated 500 surveys to secondary school science and geography teachers in every board (Puk \& Behm, 2003). When asked how much time they taught outside the school, $85.5 \%$ of grade $9 / 10$ teachers and $77 \%$ of grade $11 / 12$ science and geography teachers said that they either did not teach outdoors at all or taught outdoors for less than 5 hours per course (Puk \& Behm, 2003). Reengaging youth in their municipalities, communities, schools, and environment is essential to successful EE. Shaping Our Schools, Shaping Our Future's (OME, 2007b) vision of EE addressed some of these shortcomings by recognizing the importance of making opportunities for place-based EE a regular part of the classroom (Borland, 2015). Following the publication of Shaping Our Schools, Shaping Our Future (OME, 2007b), the Ministry of Education released a document titled Standards for Environmental Education in the Curriculum (OME, 2008). The Standards for Environmental Education "are statements that, taken together, describe the nature and scope of environmental education as it will be reflected throughout the revised curriculum. The standards will help curriculum writers devise and incorporate environmental education expectations and opportunities across the curriculum" (OME, 2008). One of three major themes in The Standards for Environmental Education in the Curriculum (2008) is Community. The standards related to community recommend that the curriculum provide students with opportunities to:

1) engage in authentic learning situations and interactions in their local environment (e.g., natural, built, cultural);

2) explore and appreciate the outdoors, to help develop their understanding of the local environment;

3) develop and communicate a sense of connection with the local and global environments; and

4) demonstrate environmental stewardship by thinking globally and acting locally. (OME, 2008) 


\subsubsection{Urban Environmental Education}

Cities are home to the majority of the world's population and this percentage continues to grow. According to Statistics Canada's (2011) Census of Population, "the proportion of people living in rural areas in Canada has steadily declined since 1851, when nearly 9 in 10 Canadians lived in a rural area. This decline is largely related to changes in the structure of the Canadian economy". Figure 1 defines rural areas as those with a population under 1000 and a population density below 400 inhabitants per square kilometer (Statistics Canada, 2011). It demonstrates a decline in the percentage of rural inhabitants from 1851 to 2011.

The positive and negative environmental influence of cities extends far beyond their borders through pollution of "the commons", consumption of and access to resources, and innovations that promote sustainability. Regardless of whether youth reside in an urban or rural setting, they require knowledge of urban environments to access the bigger picture of how society operates and the challenges that it faces. Urban EE is a branch of EE that emphasizes high population density, competition for space, and complex resource and waste

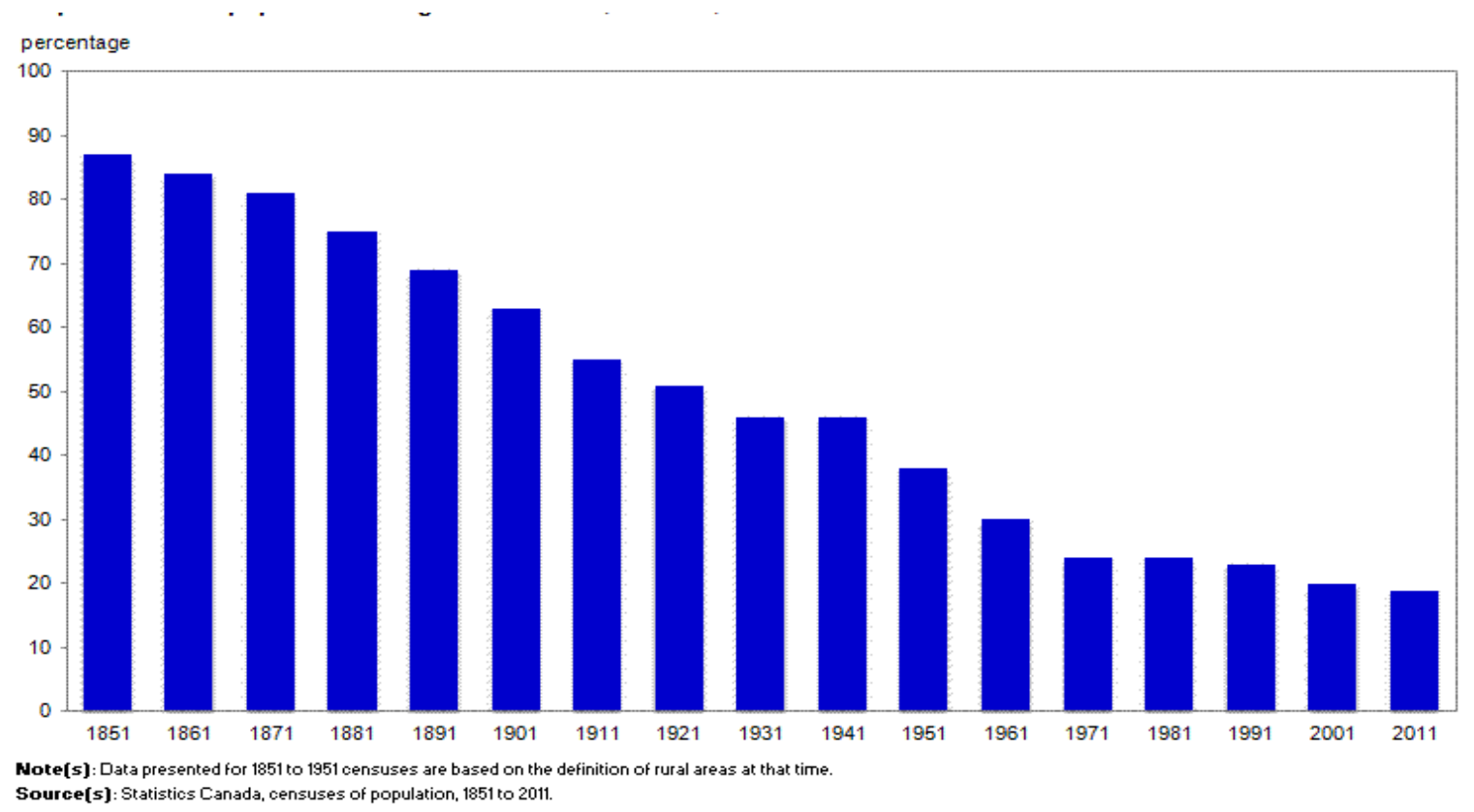

Figure 1: Proportion of the population living in rural areas, Canada, 1851 to 2011 (Statistics Canada, 2011) 
management systems (North American Association for Environmental Education (NAAEE), 2015) It deals with "specific urban social and environmental issues and opportunities" (NAAEE, 2015) such as smog, access to green space, and roof top gardens. Urban EE programs "contribute to human well-being and environmental integrity in cities" (NAAEE, 2015). Young people in both urban and rural environments need to be aware of the issues facing cities because they are not insular. Cities are huge consumers of natural resources and producers of waste and as they continue to grow, their problems have a great impact on the viability of our planet. The Ministry of Education recognizes the complexity and multidisciplinary nature of urban EE in the learning component of Shaping Our Schools, Shaping Our Future (2007) stating:

"Environmental education will draw on effective learning strategies including inquiry, problem solving, critical thinking, and assessing alternatives - that engage students personally in their own learning, connect them to the world they live in, and give them the systems thinking and futures thinking they will need to become discerning, active citizens." (OME, 2007b, p5).

Figure 2 demonstrates how place-based and urban EE fit within the greater context of environmental education. Each of these fields is defined as a subset of environmental education. When place-based EE occurs in an urban setting, the two fields overlap. Urban EE themes, such as public transit and

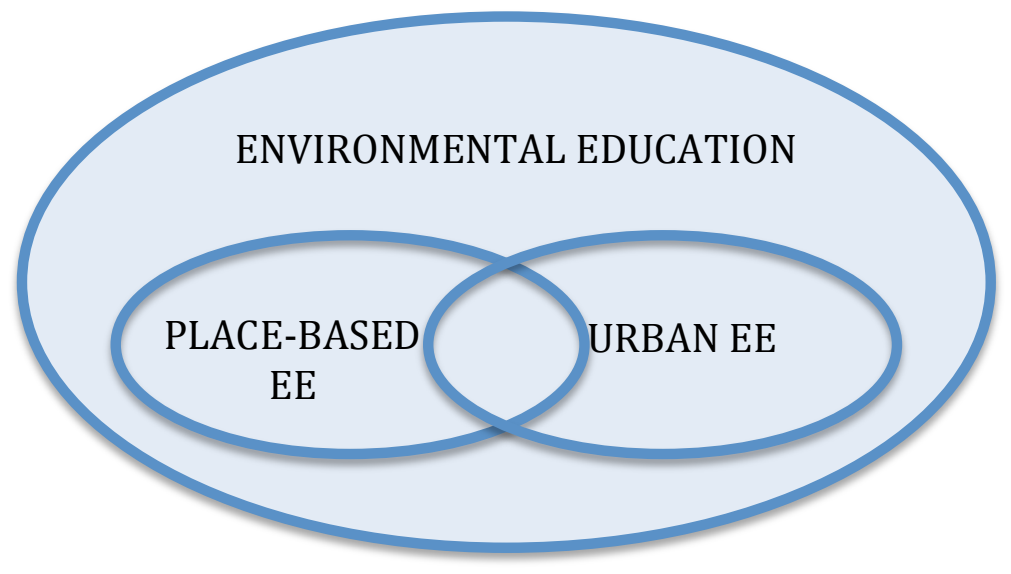

Figure 2: Realms of Urban and Place-Based EE 
access to green space, are integral to place-based studies in urban settings because they are dominant features of those environments.

Over the years, the definition of "environment" has grown from one that includes only natural elements to one that encompasses both anthropogenic and natural elements. The urban environment has limited "green space" and as urban centers grow, opportunities for interaction with the natural environment decrease (Turner et al., 2004). There is a growing disconnect between urban youth and nature as varied pursuits compete for their attention. Clearly described in Richard Louv's popular 2008 book, Last Child in the Woods, Louv argues that the youth of today are afflicted with a "nature deficit disorder" (Louv, 2008). Contributing to the disconnect with nature are too much time indoors and in front of screens, too little freedom to explore nature (especially in cities), and debilitating parental safety concerns which Louv calls the "bogey-man syndrome" (Louv, 2008). The need for urban youth to reconnect with the natural green space to which they have access is beginning to be recognized. With a stronger connection to place-based nature, urban dwellers understand the need for sustainable planning, protection of green space, and access to resources. Cities of the western world have seen a decline in the representation of youth in community planning and participation (Checkoway et al., 2003; Vancouver Working Group [VWG], 2006). It is the responsibility of those in power to provide opportunities for connection, self-efficacy, and engagement to foster a healthy youth population (VWG, 2006). Part of this comes from changing the perception of youth by adults and the public to one that focuses on their strengths and capabilities and views them as "competent citizens" capable of shaping their environment (Checkoway et al., 2003; VWG, 2006).

\subsection{Thesis Objectives}

In light of the changes made to EE in Ontario following the publication of Shaping Our Schools, Shaping Our Future (2007), how rooted is the new Ontario curriculum in place-based and urban environmental studies? The purpose of this study is to examine what Ontario is currently doing to connect youth to the place 
in which they live and to help them understand the nature of cities. It does so by analyzing the Ontario secondary school curriculum and course enrollment data and reporting on the opinions of those present at the Education Experts' Workshop (EEW) hosted by Ryerson University. More specifically, the objectives of this thesis are to:

1) determine the extent of urban and placed-based $E E$ coverage in the mandatory Ontario secondary school curriculum;

2) assess the prescriptiveness of the curriculum in this regard; and

3) provide curriculum, pedagogy, and programming recommendations to promote urban and place-based EE.

To accomplish these objectives, the following sources are used:

1) secondary curriculum and environmental policy documents,

2) enrollment data from the Ministry of Education, and

3) observations from the Education Experts' Workshop (EEW) hosted by the Faculty of Science at Ryerson University and Ryerson Urban Water (RUW) on furthering EE in Ontario. ${ }^{1}$

\footnotetext{
${ }^{1}$ On a personal note, my background and work experience are in the field of education. I have been working as a science, math, guidance counsellor, and chemistry teacher of secondary school students in the Toronto District School Board since 2006. Having worked at both private and public schools in my career, and in schools with very diverse student bodies, I have a good sense of the Ontario secondary school education system and the way in which it operates. With this experience, I bring my own biases and perspective on EE to this study. I have attempted to include these biases in an equitable manner as one of many participants in the EEW.
} 


\section{LITERATURE REVIEW}

The contextual review of this thesis has been divided into two main sections. The first provides a context for EE by describing its history and definition at an intergovernmental level. It then discusses assessment of environmental literacy and describes approaches to EE within education systems. Finally it situates place-based EE, and urban EE within the field.

The second section is less broad, focusing on the province of Ontario. It describes the structure and framework of the Ontario secondary school curriculum, and provides an overview of the current state of EE in the province of Ontario.

\subsection{Context for EE}

\subsubsection{Environmental Education}

Numerous great thinkers have influenced the evolution of EE but many ascribe its origins in the UK to Sir Patrick Geddes (1854-1933) (Palmer, 1998). Geddes, a Scottish Professor of Botany and founder of town and country planning, pioneered pedagogical approaches that placed learners into their environment (Palmer, 1998). He is responsible for opening the first field studies center in 1892, the Outlook Tower in Edinburgh, where he developed innovative methods of "Civic and Regional Surveying" (Palmer, 1998). Geddes ideas became widespread amongst the teaching community laying the groundwork for modern EE (Palmer, 1998).

It is difficult to pinpoint the first use of the term Environmental Education (EE). It is a practice that has always been in use but the term itself has increased in frequency with environmental disasters, concerns and movements worldwide since the mid $20^{\text {th }}$ century. Around this time, many parties were attempting to define the term EE to make its purpose clear (Stevenson, Brody, \& Dillon, 2012). The concept of EE developed by William Stapp in 1969 during a graduate seminar in the School of Natural Resources at the University of Michigan was formative in the field (Stevenson, Brody, \& Dillon, 2012). Stapp defined EE as 
follows:

Environmental education is aimed at producing a citizenry that is knowledgeable concerning the biophysical environment and its associated problems, aware of how to help solve these problems, and motivated to work toward their solution (Stapp, 1969).

This definition represented a significant shift from resource based "conservation education" to a concept that encompassed the community and its associated problems and collective effort towards finding solutions (Stevenson, Brody, \& Dillon, 2012).

Stapp's (1969) definition and objectives formed the basis for future definitions of EE. During the 1970s, the involvement of key international organizations increased the visibility of EE and lead to a common understanding of the term (Neal, 1994). In 1970, the International Union for the Conservation of Nature and Natural Resources (IUCN) held an "International Working Meeting on Environmental Education in the School Curriculum" defining EE as:

The process of recognizing values and clarifying concepts in order to develop skills and attitudes necessary to understand and appreciate the inter-relatedness among man, his culture, and his biophysical surroundings. Environmental education also entails practice in decisionmaking and self-formulation of a code of behaviour about issues concerning environmental quality (IUCN, 1970).

At the International Workshop on Environmental Education held in Belgrade in 1975, the International Environmental Education Program (IEEP) was created (Neal, 1994). It produced the first intergovernmental EE goal statement: To develop a world population that is aware of, and concerned about, the environment and its associated problems, and which has the knowledge, skills, attitudes, motivations and commitment to work individually and collectively toward solutions of current problems and the prevention of new ones (UNESCO, 1975).

Belgrade was followed in 1977 by the first intergovernmental Conference on Environmental Education, held in Tbilisi, USSR (UNESCO, 1978). Organized by 
UNESCO and attended by 66 member states, the report created by the conference still provides the framework for EE development in the world today (UNESCO, 1978). The conference and previous international collaboration has led to a common view of the principles and objectives of environmental education. The final report of the UNESCO conference outlines three goals of environmental education:

1) to foster clear awareness of, and concern about, economic, social, political and ecological interdependence in urban and rural areas;

2) to provide every person with opportunities to acquire the knowledge, values, attitudes, commitment and skills needed to protect and improve the environment; and

3) to create new patterns of behaviour of individuals, groups and society as a whole towards the environment. (UNESCO 1978)

The first goal differentiates between urban and rural areas. It also emphasizes the complexity of current environmental issues through its mention of interdependence among a variety of fields. The second and third goals provide opportunities to learn about the environment to enact meaningful, positive, change. Also included in the Tbilisi report is the recurrent theme of EE being:

1) about the environment (knowledge and understanding),

2) for the environment (promoting values, attitudes and positive action), and

3 ) in the environment (using the environment and first-hand experience as a resource). (UNESCO, 1978)

Following the UNESCO conference, a World Conservation Strategy was developed in 1980 (Neil, 1994). To reinforce this message of sustainable development and conservation, the World Commission on Environment and Development presided by Gro Harlem Brundtland, produced the report Our Common Future in 1987 (Brundtland,1987). Education was identified as a major theme of this report and questions about the direction that EE would take helped spark the second major U.N. conference in 1992 on the environment (Neil, 1994). The United Nations Conference on Environment and Development (UNCED), informally known as, the Earth Summit, took place in Rio de Janeiro 
and was attended by 172 governments with108 at the level of head of state or government (UNESCO, 2005). A summary of the key points related to EE made during the Earth Summit are found in Chapter 36 of the Action Programme for the $21^{\text {st }}$ century (Agenda 21). Chapter 36 , Promoting Education, Public Awareness and Training, is organized into three program areas:

1) reorienting education towards sustainable development;

2) increasing public awareness; and

3) promoting training. (UNESCO, 1992)

In this document, education, both formal and informal, are identified as "critical for promoting sustainable development and improving the capacity of the people to address environment and development issues" as well as "indispensable to changing people's attitudes" (UNESCO, 1992). In response to Chapter 36 of Agenda 21, the UN General Assembly adopted the 2005-2014 Decade of Education for Sustainable Development (UNESCO, 2005). Their primary goals were to integrate education for sustainable development in national policies and educational systems and to raise awareness of the goals of sustainable development in the public and private sectors (UNESCO, 2005).

\subsubsection{Assessment of Environmental Literacy}

The categories used to assess environmental literacy identified at the 1977 Intergovernmental Conference on Environmental Education continue to be used today comprising:

1) awareness,

2) knowledge,

3) attitudes,

4) skills, and

5) participation. (UNESCO, 1978)

Of these categories, some are more easily assessed than others, lending themselves to data collection on participation in various programs, or knowledge/skill based surveys, and tests. Methods that have been used by researchers include monitoring participation in voluntary programs (Igbokwe , 
2012) as an indicator of progress and analyzing the frequency of use of outdoor education centers (Kopar, 2013). Although attractive, concrete forms of assessment can be limiting, providing a narrow or incomplete picture of environmental literacy. Furthermore, it is difficult to interpret even simple forms of assessment without a baseline for environmental literacy, which Ontario does not yet have (Igbokwe, 2012). Recent national assessments in EE involving K-12 students have been performed in other parts of the world: South Korea (2002 2003), Israel (2004 - 2006), the United States (2006 - 2008), and Turkey (2007 - 2009) (Stevenson, Brody, \& Dillon, 2012). The International Handbook of Research on Environmental Education (Stevenson, Brody \& Dillon, 2012) acknowledges the great differences between these assessments and the enormous resources required to perform them, but commends their undertaking and underscores the benefits of going through this process and learning from the results. Using these results as a basis for comparison for future studies within the same country or between countries where applicable is recommended (Stevenson, Brody, \& Dillon, 2012).

Generally speaking, EE educators, researchers, and policymakers are beginning to realize how difficult it is to define and assess what is considered to be the ultimate goal of EE: creating environmentally responsible behavior (Stevenson, Brody, \& Dillon, 2012). The International Handbook of Research on Environmental Education (2013) goes on to say that the development of proenvironmental behavior or any behavior change "is not a simple process and that behavior change reflects nonlinear rather than linear theories of knowledge". Stevenson, Brody, and Dillon (2012) warn that research results in EE are unlikely to provide a silver bullet for developing policy and practice and that there is danger in reducing the evolution of EE to a set of practical recommendations.

Environmental education research is relatively young, with many EE journals only having started in the past 15-20 years (Stevenson, Brody, \& Dillon, 2012). According to the International Handbook of Research on Environmental Education (2012), EE research is an emerging field with "trends" in curriculum and learning research being discussed over "traditional methods". Some 
researchers go so far as to warn that if EE research is to be seen as a "cultural innovation process", that encourages "theory development", it may take the form of an "open-ended, reflexive process, not too fixed by the boundaries of research traditions and methodological frameworks, even though these are helpful to provide a mapping of an emerging field" (Stevenson, Brody, \& Dillon, 2012).

\subsubsection{Approaches to Environmental Education}

Defining EE content is a difficult task due to the environment's all encompassing nature and pervasiveness in so many fields. The Tbilisi report (UNESCO, 1978) aptly comments on the broad scope of EE content being both a strength and a weakness because EE either "becomes equated with the whole of education, thus essentially losing its identity, or else selected features must be singled out for a focus of teaching and learning tasks" (Neil, 1994). With either extreme, there is the risk of losing important aspects of EE. A combined method can overcome this problem where EE is seen as both an overarching "approach" to education but also as containing "discrete content" (Neil, 1994). Some arrangements used in secondary schools to tackle cross-curricular themes such as EE include; integrating topics into various subject curriculum, separately timetabling EE (e.g. separate course), short-block timetabling (e.g. series of subject based topics lasting for varying periods of time), and long-block timetabling (e.g. activity week) (Neil, 1994). Continuity is also a factor that must be considered in designing an EE program. Without it, EE loses its status as an overarching theme. Students undergo significant growth and development over the course of secondary school and are able to build complexity in their understanding and a relationship to the environment as they mature.

The subject-based structure of secondary schools in Ontario is a serious impediment to cross-curricular work. It is possible to work within the rigidly timetabled subject silos of secondary schools using some combination of the arrangements listed above but there are criteria that need to be met to do so. These include the provision of sufficient teacher training, and the development of a coherent and clear implementation plan, which ensures continuity and 
progression throughout the secondary curriculum (UNESCO, 1978; Neil, 1994). It is clear that Ontario has made EE a priority through the publication of Shaping Our Schools, Shaping Our Future (OME, 2007b) and the policies that followed. What is unclear is whether Ontario's approach to EE in secondary schools is accomplishing its goals.

\subsubsection{Field Study and Place-Based EE}

The Handbook of Environmental Education (Neil, 1994) opens with the belief that, "no educational programme of work in this area can be successful without individual commitment and personal concern". The word "concern" for the environment is also used in the first goal of the Tbilisi conference (UNESCO, 1978). The Handbook of Environmental Education (Neil, 1994) then describes a preliminary British study conducted by Palmer in 1993, which examines the formative experiences of environmental educators that contributed to their personal concern for the environment. Autobiographical statements from 232 individuals were collected, and subjected to a content analysis (Palmer, 1993). The themes within these statements were then coded into the 13 categories shown in Table 1. The results show that a large number of environmental educators made reference to memorable experiences outdoors, which contributed to "enjoyment of the outdoors" and "environmental care and concern" (Palmer, 1993). The second most frequent category listed in Table 1, is "Education/Courses" (Palmer, 1993). The potential for formal schooling to create "personal concern" for the environment is significant and this study concurs that the inclusion of field study or place-based education is a vital component. 
Table 1: Formative Experiences of Environmental Educators Contributing to Personal Concern for the Environment - Number of Subjects Studied N $=232$ (Palmer, 1993)

\begin{tabular}{|c|c|}
\hline Outdoors & 211 \\
\hline Education/Courses & 136 \\
\hline Parents/Close relatives & 88 \\
\hline Organizations & 83 \\
\hline TV/Media & 53 \\
\hline Friends/Other individuals & 49 \\
\hline Travel abroad & 44 \\
\hline Disasters/Negative issues & 41 \\
\hline Books & 35 \\
\hline Becoming a parent & 20 \\
\hline Keeping pets/Animals & 14 \\
\hline Religion & 13 \\
\hline
\end{tabular}

Place-based education has been linked to environmental education (EE) since its inception. It endeavors to provide purpose and relevance to the study of the environment and works towards the development of an engaged citizenry with the tools necessary to shape their communities. Woodhouse and Knapp (2000) describe the key components of place-based education as:

1) emerging from the particular attributes of place;

2) being inherently multidisciplinary;

3) being inherently experiential;

4) having a philosophical agenda that is broader than "learning to earn"; and

5) connecting the individual, community, and environment. (Woodhouse \& Knapp, 2000)

Environmental place-based education shares the components described by Woodhouse and Knapp (2000) but focuses on environmental study rather than social, economic, historical, or political study.

Community connections are vital to the success of place-based EE and show a 
number of benefits to students and communities. Sanders' (2003) article in the Journal of Education and Urban Society, describes community involvement in schools as important for effective school functioning, economic competitiveness, student well being, and community health and development. In Scandinavian and German-speaking countries, the notion of "action competence" has been an important concept in EE since the 1980s (Barratt \& Hacking, 2011). There is a definite link between pedagogy associated with action competence and placebased education (Barratt \& Hacking, 2011). In teaching students about their communities, they are empowered to develop solutions to local problems.

In many ways, traditional secondary schooling methods of sitting at desks in subject-specific classrooms are in direct contraction with place-based education EE (Smith, 2007). Despite this apparent obstacle, it has become more widespread in the past 20 years and many of its characteristics have been incorporated in curriculum models worldwide with varying success. Barratt and Hacking (2011) provide a rationale for our growing interests in place-based education describing it as "a post-positivist reaction to: globalization; centralized, abstracted curricular and standards-driven approaches; and challenges to the notion of community and voice".

The idea of using first-hand experience and out-of-classroom study is an important aspect of place-based EE. Despite the fact that this approach is commonly referred to as field study, it does not require extensive travel or access to natural areas. The "field" includes the built environment, school grounds, and even the school building. For example, a school waste audit is considered to be field study. The British National Association for Field Studies Officers describe field study as:

1) giving relevance to topics which could otherwise remain as secondhand learning;

2) concerning with real people, real situations, and real issues;

3) enabling students to record, analyse, present and interpret their own investigations;

4) providing pupils with opportunities to talk about their own world, to 
listen to others and to share their knowledge;

5) providing pupils with opportunities to look closely at aspects of a local environment and introduce the idea of environmental responsibility; and

6) providing opportunities for pupils to work cooperatively using academic, practical and social skills. (Neil, 1994)

More recent definitions of place-based EE have recognized the importance of applying a critical lens (Gruenewald, 2003). In an increasingly complex world, environmental issues are multidimensional involving dissident perspectives and diverse stakeholders. Recognizing that many of our environmental problems are a direct result of social injustice is fundamental to real EE (Gruenewald, 2003). Educators and researchers have shown the enormous benefits of using placebased education within the context of ecojustice (Lowenstein, Martusewicz, \& Voelker, 2010), to empower marginalized groups, and forge intergenerational partnerships (Mannion \& Adey, 2011), especially in secondary schools where the range in student age is small. The degree to which critical thinking is present in place-based EE curriculum is difficult to assess because it is primarily determined by pedagogical style over content.

The province of Ontario recognizes the benefits of place-based EE and assessing the degree to which it has embedded place-based EE into its secondary curriculum is one of the main goals of this study. With a provincially mandated curriculum, standardized over a large, diverse, region, it can be challenging to include outdoor education and community-specific study. Traditional EE programs often focus on fundamental ecological concepts or global issues of environmental sustainability. Accessing a different scale, placebased EE allows students to examine their communities and regions as complex, relevant areas of study to create future citizens who would engage in communitybased environmental stewardship and innovation.

\subsubsection{Urban Environmental Education}

According to the World Health Organization [WHO] (2015), greater than 50\% of 
the global population lives in urban areas, up from $34 \%$ in 1960 , and this percentage continues to grow. With the majority of the world's population living in urban areas, it is imperative that the structure, function, and factors that affect the health of cities be studied in our schools. The global population trend of urban intensification is echoed in the province of Ontario where considerable population growth is expected over the next 15 years (Ontario Ministry of Municipal Affairs and Housing [OMMAH], 2005). Ontario's "Places to Grow" plan outlines a strategy for growth that limits the amount of agricultural and forested land utilized for human residences and businesses (OMMAH, 2005). The first region to have a designated "Places to Grow" plan in place is the Greater Golden Horseshoe (GGH) area (OMMAH, 2005). According to the OMMAH (2005), Ontario's GGH area is "one of the fastest growing regions in North America" with the population expected to grow by 3.7 million (from 2001 to 2031) to 11.5 million people. To curb the environmental impact of population growth, the plan recommends intensifying growth in pre-existing inhabited areas, designating urban growth boundaries, re-utilizing brownfield sites, re- energizing public transit, and investing in urban infrastructure (OMMAH, 2005). Ontario's cities will undergo significant change over the next 15 years and they will need the help of educated and involved citizens to ensure that they grow successfully.

While cities are sometimes viewed as entities existing outside of nature, urban EE seeks to understand cities as evolving ecosystems shaped by natural and anthropogenic forces that include a social, political and economic perspective (NAAEE, 2015). Recognized as "incredibly complex, sources of pollution, and large consumers of natural resources, cities are compelled to be engines of innovation, fostering human and social capital and promoting environmental stewardship" (NAAEE, 2015). Godfrey (2010) writes in his article on urban sustainability about the convergence of environmental and urban studies and the growing consensus that "the battle for global sustainability will be won or lost in cities". The historical, architectural, cultural, socioeconomic, and political domains once dominated urban studies (Godfrey, 2010). Cities were considered to be "man made" and therefore, outside of nature while environmental studies 
were limited to the study of rural or undeveloped areas with a focus on conservation; two different worlds. Fortunately, these worlds intersected when concerns about interactions between the built and natural environment/systems grew (Godfrey, 2010). This concern gave rise to a plethora of new interdisciplinary studies, such as "environmental economics, history, literature, and science; urban ecology and environmental planning; sustainable development; and political ecology and environmental justice" (Godfrey, 2010).

Major themes that have arisen from the convergence of urban and environmental studies, as described by Godfrey (2010), have been summarized in the list below. These themes are referred to in the Methods section of this study to aid in the screening of urban EE content in the Ontario secondary school curriculum. The headings listed in brackets are the ones that are employed by this study in subsequent sections.

1) Urban Political Ecology - Governance [Politics]:

"Critically examines governmental policy, societal response, and environmental impacts of urbanization". It involves the study of environmental governance, rights and responsibilities and the forces that shape them.

2) Urban Political Ecology - Ecojustice [Sociogeographic]: Population characteristics linked to equitable access to resources. This area of study "stresses the importance of environmental justice, socioeconomic equity, and participatory governance in ecological change, including a fair distribution of both amenities and problems".

3) Urban Systems [Systems]:

The term "urban metabolism" is used to describe a "city's biophysical exchanges and accompanying regional transformations of nature". Requiring inputs and outputs that must be distributed and managed, cities must maximize cyclical process and minimize linear ones to promote sustainability. These processes include access to, and consumption and distribution of water, energy, food, waste, and other materials. 
4) Urban Geography - City Form [Planning]:

Land use studies with emphasis on sustainable design, preserving urban wilderness/green space, urban environmental restoration, and urban agriculture. Examples include "public parks, backyard or rooftop gardens, collective spaces for community gardening, green squares and plazas, reclaimed waterfronts and waterways, and public beaches".

5) Urban Geography - City Form [Immigration and Settlement]: Although not explicitly discussed by Godfrey (2010), the study of settlement trends and their impact on infrastructure is implicit to urban EE. Perhaps taken for granted, it provides secondary school students with essential context and a future outlook on the life and growth of cities.

6) Urban Geography - Ecology [Ecological]:

Concentration of buildings, impermeable surfaces, pollution, and waste create urban environmental issues such as smog, flooding, "heat islands", habitat destruction, and loss of biodiversity. These problems are not unique to cities but are representative of them. (Godfrey, 2010)

\subsection{The Ontario Curriculum and EE Policy}

Education is the responsibility of the provincial government in Canada. The Education Act legislates the duties and responsibilities of the Minister of Education, school boards, supervisory officers, principals, teachers, parents, and students (OME, 2014). In Ontario, the Ministry of Education is responsible for the development of curriculum policy and resource documents. School boards and schools are responsible for implementing them. Curriculum policy documents "identify what students must know and be able to do at the end of every grade or course in every subject in Ontario publicly funded schools" (OME, 2014). They are organized by subject (i.e. The Arts, Science, Business Studies, Canadian and World Studies) and by grade level with one document for grades 9/10 and another for grades $11 / 12$ for each subject. 
Resource documents "support implementation of policy and their use is a local decision. An example of a resource document is: Environmental Education, Scope and Sequence of Expectations, Grades 9-12, 2011" (OME, 2014).

In 2003, the Ministry established a curriculum review cycle "to ensure that the curriculum remains current, relevant, and developmentally-appropriate" (OME, 2014). Each year, a number of subject areas enter the review process. The extent of changes to the curriculum as a result of the review process is variable ranging from few changes to entire strand replacement. The curriculum review cycle involves:

1) research,

2) analysis and synthesis,

3) revision and feedback consultation,

4) editing and publication, and

5) training and implementation. (OME, 2014)

The early process involves comparison with other jurisdictions, subject research, and the use of focus groups comprised of educators from all Ontario school boards (OME, 2014). Consultations with stakeholders including the Minister's Advisory Council on special education, faculties of education, employers, parents, students, universities, colleges, other ministries, and NGOs are conducted (OME, 2014). The entire process results in recommendations actualized by writing teams from school boards across the province (OME, 2014). The documents are reviewed for content and alignment with government policies and frameworks before they are published and implemented in classrooms (OME, 2014).

\subsubsection{Curriculum policy documents}

Curriculum policy documents consist of three components:

1) the front matter provides critical foundational information about the curriculum itself and about how learning connects to Ministry of Education policies, programs, and priorities;

2) the curriculum expectations (overall and specific expectations) are 
the knowledge and skills that students are expected to demonstrate in each subject at each grade level by the end of the grade; and 3) additional supports, glossaries and overviews are included to provide further guidance and information to support the implementation of the curriculum. (OME, 2014)

An example of course curriculum structure can be found in Figure 3. Within each curriculum policy document, there are a number of courses. Each course has several strands (formerly known as units). Strands are defined by a set of overall expectations, which have their own specific expectations. The overall expectations "describe in general terms the knowledge and skills that students are expected to demonstrate by the end of each course" (OME, 2014). The specific expectations serve the same purpose but provide greater detail. Expectations vary greatly in their nature depending on the subject, course, and objective. They range from the very explicit or direct in their content (i.e. definitions, laws) to the general or indirect in their content (i.e. skills based, investigative). Within a specific expectation it is not unusual to find examples and/or sample questions (OME, 2014). The examples and sample questions

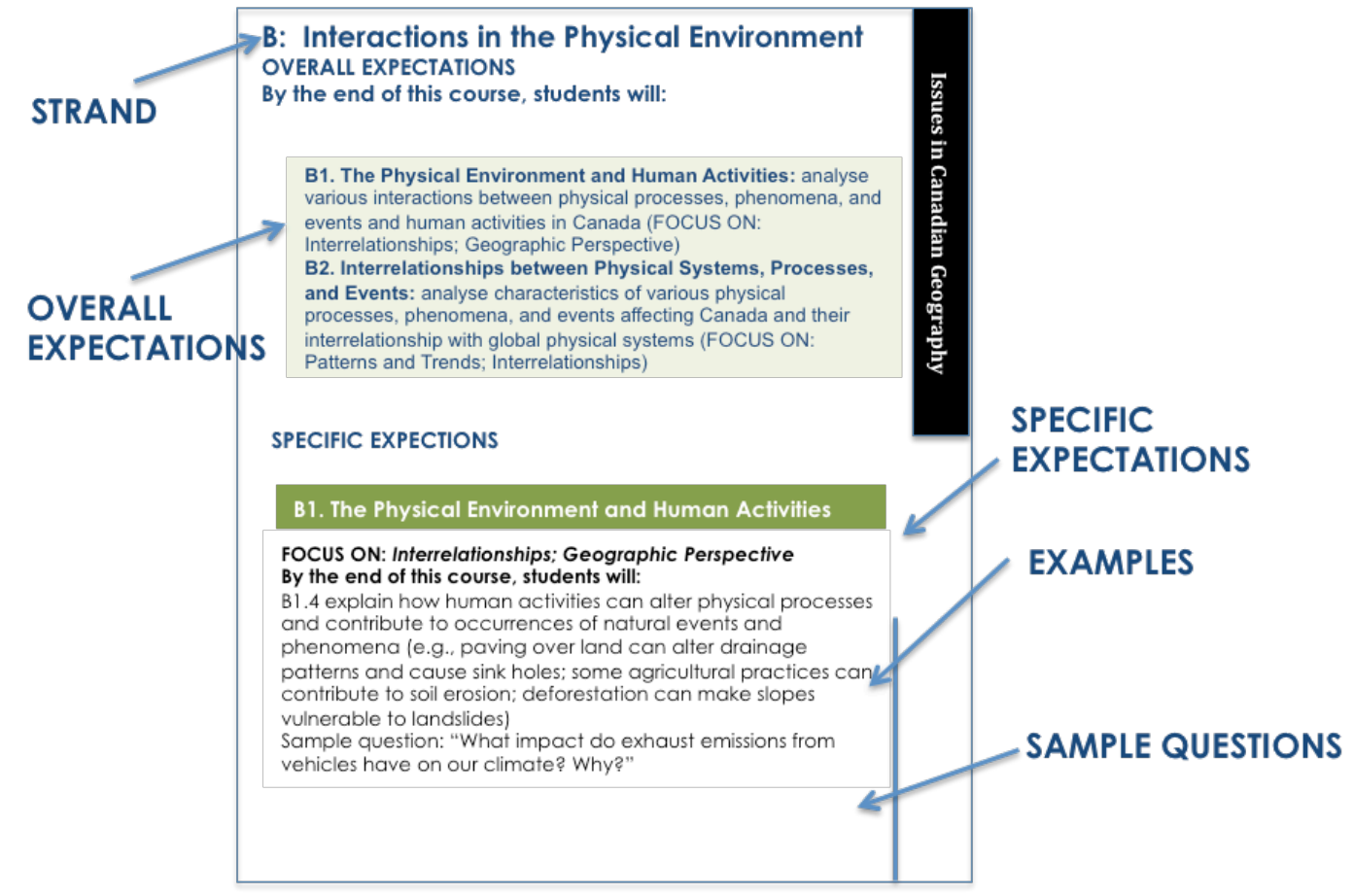

Figure 3: Curriculum Structure (OME, 2014) 
provide clarification, guidance and/or possible directions for study. It is often not possible to pursue all of the possible opportunities described in the examples and sample questions section. The specifics are for departments, teachers, and students to decide upon in their individual schools and classrooms. This can serve as both a benefit and a detriment. The benefit is that it empowers educators and students to take control of their own education and tailor lessons to their needs and interests. On the other side of the coin, important concepts can be covered superficially or ignored if they not made prescriptive enough. One of the objectives of this study is to examine what proportion of urban and placebased EE content is directly mandated in curriculum policy documents and what proportion is presented as a possible avenue for study.

Together, policy frameworks, resource documents, and curriculum policy documents guide EE in Ontario. Their vision, content, wording, and use, must therefore have clarity and cohesiveness to be effective. With public education being such a highly contested domain rife with competing priorities (i.e. literacy, numeracy, equity), the Ministry's goals for environmental education must be strongly worded and clearly visible to the parties implementing them. They must also be supported and continuously assessed if they are to thrive.

\subsubsection{History of EE in Ontario - Past to Present}

Over the past several decades, the province of Ontario has seen many changes in its approach and commitment to environmental education (EE) in secondary schools. From the late 1980s to the late 1990s Ontario secondary schools offered two Environmental Science courses in grade 10 and 12 containing units such as microbiology, environmental health hazards, environmental air and water quality (Puk \& Makin, 2006). With these courses designated as "electives", just over a quarter of schools in Ontario were offering them (Cundiff, 1989). Under the Conservative government of Premier Mike Harris in 1998, the "stand-alone" Environmental Science courses dedicated to EE were removed from the curriculum (Puk \& Behm, 2003). Furthermore, the funding and infrastructure for outdoor education programs was cut (Kopar, 2013). 
In their stead, the Ministry made a decision to "infuse" environmental science content into other subjects such as biology, physics, chemistry and geography (Puk \& Makin, 2006). Described by many as a "patchwork approach" rather than a concrete plan, the new model did not sit well with the public (Puk \& Behm, 2003; Environmental Education Ontario, 2003). General concern arose from these changes as was indicated by the creation of a number of grassroots organizations such as EEON (Environmental Education Ontario) and OSEE (Ontario Society for Environmental Education).

Of particular significance was the aforementioned study by Puk and Behm (2003) which was published in the Canadian Journal of Environmental Education in 2003 and titled "The Diluted Curriculum: The Role of Government in Developing Ecological Literacy as the First Imperative in Ontario Secondary Schools". This study disseminated 500 surveys to secondary school science and geography teachers in every board, asking them to report on the coverage of materials from the cancelled Environmental Science course in their other subjects (Puk \& Behm, 2003). Teachers were asked if they taught certain topics, how much time they spent teaching these topics, and how much time they spent per course teaching outdoors (Puk \& Behm, 2003). The study's results showed poor coverage in the new curriculum of the topics formerly included in the Environmental Science courses concluding that:

The data collected from the surveys demonstrate that grade 9/10 and grade 11/12 science and geography teachers are, in fact, spending very little time teaching ecological concepts. There is a limited and ineffective emphasis on learning about environmental science topics or promoting ecological literacy in the current curriculum guidelines. The results of the study indicate the failure of the "infusion model" for ecological education (Puk \& Behm, 2003, p.1).

With all of these changes taking place within a provincial and international climate of growing concern for EE, constructive action had to be taken. In 2007, under the Liberal government of Premier Dalton McGuinty, concerted efforts 
were made to improve the condition of EE in Ontario schools (Kopar, 2013). The Ministry of Education's Curriculum Council convened a Working Group on Environmental Education with the mandate, "to analyze needs and research successful approaches to teaching and learning about the environment in elementary and secondary schools" (Ontario Ministry of Education [OME], 2007). Chaired by Dr. Roberta Bondar, the panel published a report in 2007 titled Shaping Our Schools, Shaping Our Future (OME, 2007b). This report, which will be referred to as "the Bondar Report", demonstrated a great step forward in reshaping EE in the province of Ontario. It provided a clear definition for EE and presented the following vision for EE in Ontario.

Ontario's education system will prepare students with the knowledge, skills, perspectives, and practices they need to be environmentally responsible citizens. Students will understand our fundamental connections to each other and to the world around us through our relationship to food, water, energy, air, and land, and our interaction with all living things. The education system will provide opportunities within the classroom and the community for students to engage in actions that deepen this understanding (OME, 2007b).

In addition to the vision statement, the report stated its intended outcomes, and offered a series of recommendations for an integrated approach to EE in Ontario. The most significant change that came from the Bondar Report's recommendations was the integration of $E E$ into all grade and subject curriculum (OME, 2009). This was a significant shift from stand-alone courses to an integrated approach where the responsibility for EE lies with all educators. The report identified three core policy components for the successful implementation of EE in Ontario:

1) Leadership and Accountability,

2) Curriculum, and

3) Teaching and Resources. (OME, 2007b)

The first component recommends development of clear EE policy and programs, assessment mechanisms for monitoring student achievement, accountability 
measures for school boards and schools, and environmentally responsible operations and facilities management (OME, 2007b). The second component recommendations are listed in greater detail as they are central to this study. The curriculum recommendations are as follows:

1) Increase cross-curricular focus by embedding EE expectations in all subjects, disciplines, and grades;

2) Map the scope and sequence of EE expectations across the curriculum and incorporate review cycles;

3) Incorporate in front matter, and other appropriate sections of curriculum documents, information stressing policy vision of EE and subject specific considerations;

4) Ensure that the elementary and secondary curriculum is written to include an environmental perspective and that it meets the established standards through the curriculum review process;

5) Ensure that the curriculum provides an opportunity for elementary students to study explicitly an environmental topic in each grade, and that curriculum expectations, particularly in the elementary grades, specify that students explore and investigate their local environment, and contrasting environments outside their local area, wherever reasonable for the subject matter;

6) Ensure that all secondary students are exposed to EE though its substantial presence in compulsory Grade 9 Geography, Grade 9 and 10 Science, and Grade 10 Civics expectations (in recognition that secondary students have reached a critical capacity to engage more deeply in environmental education);

7) Identify and support opportunities to engage students in environmental action projects within the current Civics course;

8) Ensure that secondary students have the opportunity to take at least one additional course with an environmental focus during their senior high school program (preferable in Grade 11 to maintain continuity);

9) Identify interdisciplinary links for environmental education at the 
secondary level so that schools can offer integrated programs of courses with an environmental theme;

10) Develop a Specialist High Skills Major ${ }^{2}$ program offering in the environment, energy, or natural resources sectors and share effective practices associated with these and other integrated environmentally themed learning opportunities; and

11) Encourage and support cooperative education teachers and leaders to develop and share a wide variety of environmental placement opportunities that meet ministry policy and guidelines, through partnerships with local business education councils, training boards, and employers.

*In addition, it is suggested that students be encouraged to fulfill, in an environmental endeavor, some of the 40 hours of community involvement required for graduation. (OME, 2007b)

The final component recommends the inclusion of pre-service and in service EE programs as well as resource development to build teacher confidence and capacity to teach EE.

Following the release of the Bondar Report, the Ontario Ministry of Education published the policy framework, Acting Today, Shaping Tomorrow: A Policy Framework for Environmental Education in Ontario Schools (OME, 2009). The framework describes strategies and actions, which are assigned to the school, board and ministry levels to develop accountability. It also recognizes the importance of place-based education and "increasing student engagement by fostering active participation in environmental projects and building links between schools and communities" (OME, 2009). The key actions described by the policy framework include:

1) Adopting an integrated approach that embeds environmental curriculum expectations in the majority of grades and subjects;

2) Creating and Updating of EE Resource Documents

\footnotetext{
2 Students receive the SHSM seal on their diploma when they: "complete a specific bundle of 810 courses in the student's selected field; earn valuable industry certifications including first aid and CPR qualifications; and gain important skills on the job with employers." (OME, 2014)
} 
(a) Environmental Education: Scope and Sequence of Expectations (2011) - a document highlighting opportunities for the inclusion of $E E$ in secondary school curriculum courses (OME, 2011);

(b) Ready, Set, Green! (2007) - a document sharing school and student projects across the province that demonstrate engagement in environmental stewardship (OME, 2007a);

3) Creating Environmental Plans/Frameworks and EE Professional Learning Committees (PLC) at the school and board levels;

4) Supporting $E E$ for teachers through the creation of pre-service teacher programs, additional qualification courses, and PD opportunities;

5) Offering community linked experiences and programs such as the Specialist High Skills Major (SHSM); and

6) Improving the management of resources, operations, and facilities. (OME, 2009)

The Bondar Report and policy framework came at a time when EE was gaining recognition. It shed light on the inadequacies of EE in Ontario and was well received by the mainstream media and the general public as a step in the right direction; however, it was not without its critics. An article by Bruce Pardy (2010) in the Ontario Journal for Outdoor Education was particularly critical of Ontario's new EE policy. Pardy's (2010) first point of contention is that "rather than seeking to develop independent thinking about environmental issues, the framework's primary objective is to instill orthodox environmental values". He identifies a lack of critical thinking, too great a knowledge/skills focus, and oversimplification of environmental issues. Pardy's second critique is that of shallow integration of EE into a rigid system that does not enable students to experience the world outside the classroom (Pardy, 2010).

Successes and impediments to the implementation of recommendations made by the Bondar Report are still in the process of being identified. They are discussed in more detail in the next section.

In 1999, the Ontario government added a grade 10 Civics class and 40 hours of community service to its secondary school graduation requirements 
(Henderson et al., 2007). These changes were made with the goal of improving youth civic engagement and they occurred in conjunction with the removal of the fifth year of high school. Mandatory community service may require students to volunteer for a set number of hours for credit, or it may involve "service-learning, where the goals or lessons of service are reinforced by the course curriculum" (Henderson et al., 2007). The latter have been seen to be more effective in improving civic responsibility (Henderson et al., 2007).

Shortly before the release of the Bondar Report, the Ontario government released news that it was creating a new Program Enhancement Grant with a value of $\$ 35$ million (Kopar, 2013). Alongside the changes in EE, the grant's funds were to be equally available to programs in arts, music, physical education and outdoor education with a maximum of $\$ 7500$ per school (Kopar, 2013). In 2012 , the Ministry made a portion of the grant more directly applicable to outdoor education by transferring $\$ 20$ million to outdoor learning activities provided by school boards or by third party organizations, such as community agencies (Kopar, 2013).

\subsubsection{Barriers to the Implementation of EE in Ontario}

In 2010, Tan and Pedretti performed a study at the Ontario Institute for Studies in Education (OISE) identifying the "challenges and complexities" to implementing EE in the province of Ontario. They collected 300 responses to an internet-based survey questionnaire, and conducted 24 teacher interviews from across the province (Tan \& Pedretti, 2010). The majority of individuals in the study group were secondary school teachers with $\sim 58 \%$ working in urban areas and $\sim 40 \%$ based in the Greater Toronto Area (Tan \& Pedretti, 2010). The key results of Tan and Pedretti's 2010 study are described as:

Our findings suggest that there is a significant gap between teachers' views of what environmental education should be and what they currently practice. Challenges and complexities identified by participants include overcrowded curriculum, lack of resources, lack of alignment between curriculum and existing ministry expectations, low priority of environmental 
education in schools, access to the outdoors, apathy, and the nature of sociopolitical action (Tan \& Pedretti, 2010).

Echoing some of the concerns raised by Tan and Pedretti's study, is a Masters research paper by Chowdhury (2015) at O.I.S.E. which used four semi-structured teacher interviews to explore the implementation of EE in Ontario. Chowdhury's (2015) recommendations included raising teacher awareness of EE policy documents, and improved accountability measures for EE programming and policy implementation.

A follow-up study performed by Pedretti et al. in 2012, looked at Ontario teachers' perspectives of environmental and outdoor education. Their survey of 377 Ontario teachers showed a lack of professional development and pre-service education in these areas and that the majority of knowledge in these domains came from personal studies/interest (Pedretti et al, 2012). Varied commitment to and comfort with EE and outdoor education were also noted. Interestingly, 60\% of surveyed teachers supported the integration model for EE with the others lobbying for stand-alone courses and alternative approaches. Those teachers opposed to the integration model may have shared Pardy's concerns of shallow integration or may have struggled with the practical difficulties of a full integration.

A study by Steele (2011), which followed the work of six secondary science teachers in Ontario as they integrated EE into their science lessons, demonstrates the juxtaposition between conventional science and $\mathrm{EE}$ pedagogies. Despite the fact that science is considered to be an excellent vehicle for EE because of its overlapping content, the way in which traditional science is taught is at odds with EE (Steele, 2011). Some of the impediments that surfaced in Steele's (2011) study included "the scientific knowledge base that is deemed necessary for students, the approval of colleagues, issues of assessment and evaluation, and the influence of textbooks". Steele (2011) also references Stevenson (2007)'s list of school-related barriers to implementing EE which include:

1) the problems with classroom management that result in more highly structured teaching approaches and focus on content learning, 
2) the necessity of evaluation and grading of students that is far more easily managed with content knowledge and cookbook activities, and

3) science itself is considered an objective inquiry and thus the teaching (and evaluation of learning) of science has remained objective. (Stevenson, 2007)

While these studies exhibit differing objectives and methods, many of them indicate the need for greater teacher preparedness. In 2013, the Ontario Institute for Studies in Education (OISE) hosted a roundtable discussion to develop a strategy for EE in initial teacher education programs. The roundtable and resource guide that was produced was titled DEEPER, Deepening Environmental Education in Pre-Service Education Resource (OISE, 2013). It was created to address the feelings of unpreparedness felt by teachers to implement EE in their classrooms (OISE, 2013). DEEPER was also a much needed step in addressing the key action item raised by the policy framework, Acting Today, Shaping Tomorrow (2009), to support teachers through "the creation of pre-service teacher programs" (OME, 2009). Another such initiative that has yet to occur is the National Roundtable in Environment and Sustainability Education in Pre-service Teacher Education, which will be hosted by Trent University from July 14-16, 2016.

Subject association groups in Ontario have existed in traditional subjects such as Mathematics, Science, and English, for decades. They consist of educators that are interested in sharing innovative ideas, approaches, lessons, and resources in their discipline. Most are funded through a membership fee model but the more established ones, like the Science Teachers' Association of Ontario (STAO), can also be subsidized by the government. New to these groups is the creation of EE teacher communities such as the Ontario Society for Environmental Education (OSEE) and The Council of Outdoor Educators of Ontario (COEO). They are currently quite small and are often underpublicized. This limits their funding and ability to thrive as they rely heavily on membership fees and volunteer efforts. 


\subsection{Conclusions}

Ontario is finally starting to recognize the importance of EE to the future of its citizens and the planet as a whole. The momentum that Ontario has generated with the Bondar Report must not be lost. Ontario must continue to learn from itself and the international community. Place-based and urban studies are at the heart and forefront of EE and the extent to which they are focused on in secondary school studies has a great impact on the environmental literacy of youth in the province. If EE in Ontario is to grow, the wings that it needs to be successful, the barriers in its way need to be removed. Students and educators who are passionate about EE are making progress but should not have to fight this hard for opportunities and resources. For those who do not share this passion or expertise, EE needs to be made a priority through raised awareness and training. Part of the solution is continuing to draw attention to the problem until it cannot be ignored. 


\section{METHOD}

To assess the depth and breadth of the Ontario secondary school curriculum in place-based and urban EE, this study uses three different methods. The first method identifies urban and place-based EE implementation barriers through a summary of the perspectives of educators offered at the Education Experts Workshop. The second involves a content analysis of curriculum expectations in mandatory courses to identify opportunities for urban and place-based EE and assess their prescriptiveness. The mandatory courses examined were those in which EE was made prominent as per the Bondar Report. The curriculum expectations within them are classified as either overall or specific expectations, and contain examples, and sample questions. To analyze prescriptiveness, these expectations were categorized as directly related to urban and place-based EE if they required its study. Expectations that provided the opportunity to study urban and place-based EE without requiring it, were categorized as indirect. The third method identifies elective courses with substantial urban and place-based EE content and examines enrollment and course offerings subsequent to the Bondar Report. Together, these methods were used to assess the progression and continuity of urban and placed-based EE in secondary schools.

Since this study utilizes EEW workshop observations, a content analysis of curriculum expectations, and examination of enrolment data, it contains three methods. These methods are expounded upon in the sections that follow.

\subsection{Education Experts' Workshop: Implementing 2007 Bondar Report's Intended Outcomes in 2015}

On April 1 2015, the Faculty of Science at Ryerson University and Ryerson Urban Water (RUW) hosted the Education Experts' Workshop: Implementing 2007 Bondar Report's Intended Outcomes in 2015. The Education Experts' Workshop (EEW) brought together 31 representatives from the Ontario Ministry of Education (OME), the Ministry of the Environment and Climate Change (MOECC), NGOs doing EE-related work, extracurricular education centers, conservation authorities, Faculties of Education, principals, and teachers for the 
shared purpose of:

a) Discussing the evolution and current state of EE in Ontario schools (K-12);

b) Identifying existing barriers to the successful implementation of EE; and

c) Producing a comprehensive and shared plan, which addresses the challenges raised.

A full participant list, EEW agenda, and invitation can be found in Appendix B.

The format for the workshop was a series of roundtable discussions. The roundtables, facilitated by Ryerson faculty members, were first organized by peer group to share their expertise and perspective on the evolution, current state, and impediments to EE in Ontario. The second set of roundtables consisted of mixed stakeholder groupings designed to collaborate on a shared vision for overcoming the challenges raised by the first roundtables. Several note takers were present at each of the tables. They consisted of Ryerson faculty members, and graduate students (including myself).

The EEW was designed to be the first in a series of dialogues that examines the challenges faced in moving EE to the forefront of K-12 public education. Convergent with the purpose of this study, the topics of EE curriculum, placebased EE, and urban EE were discussed at length by the stakeholder groups present at the workshop.

After the event, the following steps were taken to apply the information gathered at the workshop to the third objective of this study in order to provide curriculum and programming recommendations which further urban and placebased EE.

1) Collection of observations (hand written notes, formal summaries, chart paper group summaries) from note takers present at each of the roundtables,

2) Review of observation to identify congruencies between note takers and common threads in participant perspectives,

3) Consolidation of the predominant perspectives on the current state of $E E$ and barriers to its implementation in the form of a white paper titled Education Experts' Workshop: Implementation of The Bondar Report 2007 
(EEW, 2015),

4) Dissemination of white paper to EEW participants for review and feedback, and

5) Preparation of synopsis applicable to urban and place-based EE inclusive of a discussion that provides perspective, purpose, and recommendations to the curriculum review and enrolment data analysis.

Similar to case studies and interviews, workshops and roundtable discussions are subjective in nature. Although difficult to substantiate, these types of studies provide vital information on how policy is made into practice.

\subsection{Curriculum Review}

This section describes the curriculum review performed on specific mandatory courses for urban and place-based EE content. First, it lists the courses identified for review and explains the rationale for their selection. Then it describes how urban and place-based EE curriculum expectations were recognized and the criteria used to classify them as having a "direct" or "indirect" relation to these topics. Finally, it explains the process by which curriculum expectations having urban or place-based EE content were further analyzed to identify opportunities for field study and/or participatory and action outcomes.

\subsubsection{Selection of Courses for Curriculum Review}

To obtain a secondary school diploma in the province of Ontario, a student must meet the requirements listed in Table 2. Of the thirty credits outlined in Table 2, eighteen are mandatory. Credits are obtained upon successful completion of a course. Courses generally have a value of one credit with rare exceptions like Civics and Citizenship (CHV2O) and Career Studies (GLC2O), which count as half credits. The curriculum review section of this study only focused on the credits that students are required to take to obtain their O.S.S.D.. These are the only courses taken by every Ontario secondary school student and as such, they represent a standard environmental curriculum across the province. Within the eighteen mandatory credits in Table 2, some offer more 
selection than others. For example, the Group 1, 2, and 3 requirements are very broad, and the Arts requirement can be taken in courses ranging from visual arts and drama, to graphic design and music. To narrow the focus of this study to one that was manageable for graduate study and select credits that truly represented a standardized environmental curriculum, the Arts and Group 1, 2,

Table 2: O.S.S.D. Requirements (OME, 2014)

\section{O.S.S.D. Requirements - 18 compulsory credits}

4 credits English (1 credit per grade)

3 credits Mathematics (1 credit in Grade 11 or 12)

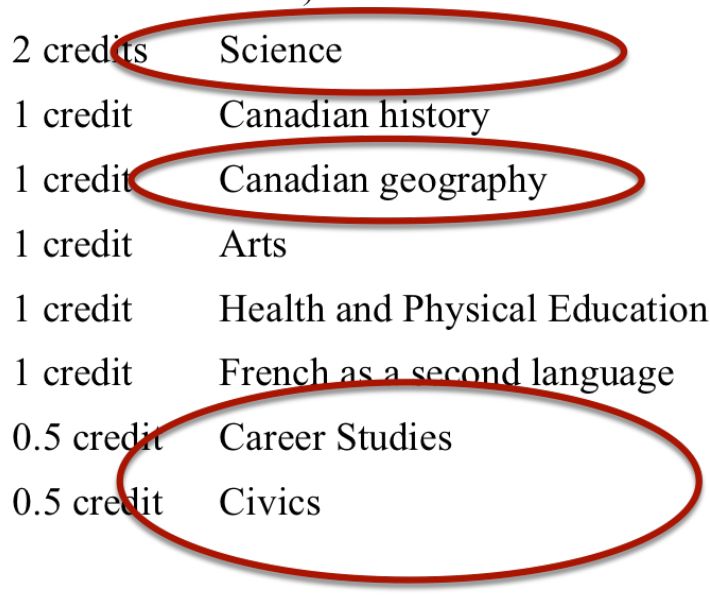

Group 1: (1 credit) English or French as a second language, a Native language, a classical or an international language, social sciences and the humanities, Canadian and world studies, guidance and career education, cooperative education

Group 2: (1 credit) health and physical education, the arts, business studies, French as a second language, cooperative education

Group 3: (1 credit) science (Grade 11 or 12), technological education, French as a second language, computer studies, cooperative education

- $\quad 12$ optional credits

- 40 hours of community involvement activities

- the provincial literacy requirements (OSSLT)

and 3 requirements were not included in the review. Recommendations within the Bondar Report regarding credits with the greatest potential for EE content prompted further narrowing of the study to credits in Geography, Science, and Civics. The Bondar Report states: 
Since virtually all secondary students, to meet diploma requirements, take courses in Grade 9 Geography, Grade 9 and 10 Science, and Grade 10 Civics, it is important that expectations related to environmental education be prominent in these courses. Currently, courses in Grade 9 geography and Grade 10 science offer a number of opportunities for environmental education. This focus should be reinforced to complement and extend student knowledge, skills, and perspectives (OME, 2007b).

In addition to the courses recommended by the Bondar Report, the following credits were also included in this study:

1) Career Studies - included because it is often delivered in conjunction with Civics, and

2) Workplace Environmental Science - included because it can count as a second mandatory science credit (prerequisite is grade 9 academic or applied science).

The courses identified by this study can be available at multiple levels known as course types (i.e. open, academic, applied, and workplace). Descriptions of each of these course types are provided in Table 3. In general, grade 9 and 10 courses are only offered as academic, applied and open. These courses lead to grade 11 and 12 university, mixed, college, and workplace course types. Grade 9 academic courses lead to grade10 academic courses, which are prerequisites for the grade 11 and 12 university, and mixed level courses. Grade 9 applied courses lead to grade 10 applied courses, which are prerequisites for the grade 11 and 12 mixed, college and workplace courses. Open courses usually have no prerequisites in grade 9 and 10, and applied or open prerequisites in grade 11 and 12. As such, a student can take multiple pathways through the mandatory curriculum and still meet their O.S.S.D. requirements. These pathways are outlined in Figure 4. Since the pathways through the Ontario curriculum stem from two main course types in grade 9, they are often referred to as the academic and applied pathways. The difference between urban and placebased EE coverage in the academic and applied pathways was also assessed by this study. Table 4 provides a complete list of all of the courses that were 
identified for review by this study.

Table 3: Description of Course Types (OME, 2014)

\begin{tabular}{|c|c|}
\hline COURSE TYPE & DESCRIPTION \\
\hline Academic & $\begin{array}{l}\text { Academic courses develop students' knowledge and skills } \\
\text { through the study of theory and abstract problems. These } \\
\text { courses focus on the essential concepts of a subject and } \\
\text { explore related concepts as well. They incorporate practical } \\
\text { applications as appropriate }\end{array}$ \\
\hline Applied & $\begin{array}{l}\text { Applied courses focus on the essential concepts of a subject, } \\
\text { and develop students' knowledge and skills through practical } \\
\text { applications and concrete examples. Familiar situations are } \\
\text { used to illustrate ideas, and students are given more } \\
\text { opportunities to experience hands-on applications of the } \\
\text { concepts and theories they study. }\end{array}$ \\
\hline Open (gr. 9/10) & $\begin{array}{l}\text { Open courses are the only type of course offered in most } \\
\text { subjects other than those listed above. They are designed to } \\
\text { prepare students for further study in a subject, and to enrich } \\
\text { their education generally. Open courses comprise a set of } \\
\text { expectations that are appropriate for all students. }\end{array}$ \\
\hline Open (gr. 11/12) & $\begin{array}{l}\text { Open courses are designed to broaden students' knowledge } \\
\text { and skills in subjects that reflect their interests and to prepare } \\
\text { them for active and rewarding participation in society. They } \\
\text { are not designed with the specific requirements of } \\
\text { universities, colleges, or the workplace in mind. }\end{array}$ \\
\hline Workplace & $\begin{array}{l}\text { Workplace preparation courses are designed to equip } \\
\text { students with the knowledge and skills they need to meet the } \\
\text { expectations of employers, if they plan to enter the workplace } \\
\text { directly after graduation, or the requirements for admission to } \\
\text { certain apprenticeship or other training programs. }\end{array}$ \\
\hline
\end{tabular}

Also included in the O.S.S.D requirements in Table 2, is the mandatory community service requirement. This study does not focus on the mandatory service requirement because data on the nature of activities (i.e. environmental or not) is very difficult to obtain. Currently, mandatory service forms are completed by hand. A supervisor and guidance counselor approve the activity before it is recorded as a total number of hours in an electronic database. There is currently no electronic database which includes a description of the activities nor is there any requirement that it be environmental in nature. 


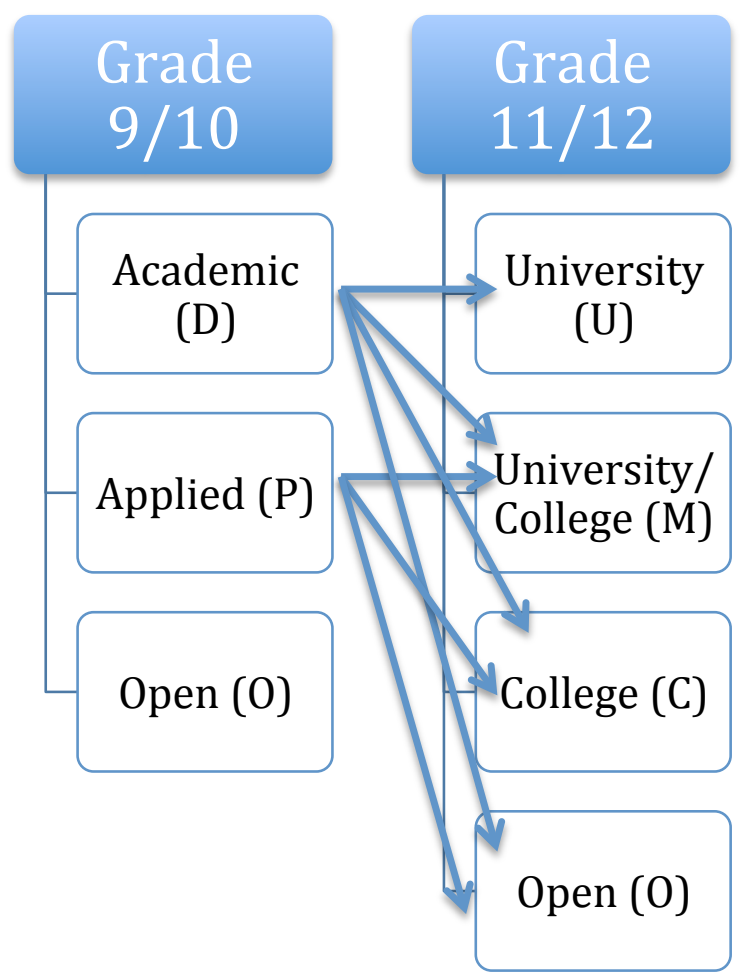

Figure 4: Course Pathways

Table 4: Mandatory Courses Identified for Curriculum Review

\begin{tabular}{|c|c|c|c|}
\hline GRADE & COURSE TITLE & TYPE & $\begin{array}{c}\text { COURSE } \\
\text { CODE }\end{array}$ \\
\hline 9 & Issues in Canadian Geography & Academic & CGC1D \\
\hline 9 & Issues in Canadian Geography & Applied & CGC1P \\
\hline 10 & Civics and Citizenship & Open (0.5 credits) & CHV2O \\
\hline 10 & Career Studies & Open (0.5 credits) & GLC2O \\
\hline 9 & Science & Academic & SNC1D \\
\hline 9 & Science & Applied & SNC1P \\
\hline 10 & Science & Academic & SNC2D \\
\hline 10 & Science & Applied & SNC2P \\
\hline$* 11$ & Environmental Science & Workplace & SVN3E \\
\hline
\end{tabular}

*Included because it can count as second mandatory science credit (prerequisite is grade 9 academic or applied science)

To describe a curriculum expectation in the sections that follow, the headings below are used. A full list of urban and place-based EE expectations containing these headings can be found in Appendix A. 
1) Grade $(9,10,11$ or 12$)$,

2) Course Title,

3) Course Type (e.g. Academic, Applied, Open, Workplace),

4) Course Code (an abbreviation used to identify the subject, grade level and course type),

5) Strand,

6) Expectation Type (overall or specific),

7) Expectation,

8) Examples, and

9) Sample Questions - Not all expectations include examples and sample questions.

\subsubsection{Approach to Curriculum Review}

To review the mandatory courses identified for curriculum review a qualitative content analysis was conducted. A constant comparative approach was used to create and define the criteria used to code the data (Hsieh \& Shannon, 2005). According to Hsieh and Shannon (2005), the method can be defined as an "open and explorative approach, such as in the form of a thematic analysis in which categories are constructed inductively". In other words, the researcher is required to compare data to create categories that undergo content and definition changes as the data are compared and categorized. For this reason it is thought of as an inductive or evolutionary approach rather than deductive approach which clearly defines at the outset what will be found (Hsieh \& Shannon, 2005). In this study, themes, identified by the literature review, were used to determine if curriculum expectations were related to urban and place-based EE. The criteria used to identify these themes and their prescriptiveness, such as the presence of key words, were defined and redefined using a constant comparative approach. Curriculum expectations are qualitative and diverse in nature. Their focus ranges from a skills basis to a content basis and their prescriptiveness varies as a result. A constant comparative approach is well suited to these kinds of data because it can be constructed based on the type of language present in curriculum 
expectations and evolves to accommodate its variability.

\subsubsection{Curriculum Review Method}

To identify curriculum expectations related to urban and place-based EE, clear criteria had to be established. This proved to be a challenge because of the variability in data and the breadth of the topics themselves. Urban and placebased EE themes that emerged from the literature review were used as a starting point. These themes were used to identify expectations related to urban and place-based EE. In this way, the approach to classifying expectations was deductive with pre-established criteria. Inductive elements were introduced to the method as the curriculum expectations were reviewed. To determine if any of the themes applied to an expectation, a combination of key words and subject matter distinctive of the curriculum documents were established. These criteria evolved using a constant comparative approach. Furthermore, the set of themes itself was expanded to include additional themes consistent with urban and place-based EE. The presence or absence of themes and key words was then used to categorize the data. Raw counts of curriculum expectations were used to provide an indication of content coverage. It should be noted that the Ministry of Education does not equally weigh curriculum expectations. There are no Ministry criteria stipulating that equal amounts of time be spent on each curriculum expectation as they are very diverse in nature and lend themselves to different instructional strategies. The methods used to perform the curriculum review are described in detail in the sections that follow.

\subsubsection{Identify Curriculum Expectations with Place-Based and/or Urban EE Content}

Using the six themes derived from Godfrey's (2010) convergence of urban and environmental studies in the literature review (Section 2.1.5),

1) Urban Political Ecology - Governance [Politics],

2) Urban Political Ecology - Ecojustice [Sociogeographic],

3) Urban Systems [Systems], 
4) Urban Geography-City Form [Planning],

5) Urban Geography - City Form [Immigration and Settlement],

6) Urban Geography - Ecology [Ecological],

and one theme derived from Woodhouse and Knapp's (2000) key components of place-based education,

7) Sustainability, seven themes were highlighted as opportunities to pursue place-based and/or urban EE. They are typical of both urban and place-based EE. The theme of "Sustainability" stemmed from the concept that place-based education: is inherently experiential (i.e. includes participatory action or service learning); has a philosophical agenda that is broader than "learning to earn"; and connects the individual, community, and environment (Woodhouse and Knapp, 2000). Upon reviewing the curriculum expectations, an eighth theme,

8) Climate.

was added to the list to include expectations related to place-based climate study which had not been accounted for by the original seven themes.

Within each of the courses listed in Table 4, curriculum expectations (overall or specific), their associated examples, and sample questions were screened for content in any of these eight themes. Curriculum expectations were also selected if they offered the opportunity to study these themes but did not necessitate an environmental focus. Table 5 summarizes and describes the eight themes identified by the literature and curriculum review. The way in which these themes were applied to the curriculum expectations is described in the sections that follow. 
Table 5: Themes in Urban and Place-based EE

\begin{tabular}{|l|l|}
\hline Topic & Description \\
\hline Politics & governance / rights / responsibilities \\
\hline Sociogeographic & general population characteristics \\
\hline Systems & waste, transportation, energy, food, water \\
\hline Planning & land use \\
\hline $\begin{array}{l}\text { Immigration and } \\
\text { Settlement }\end{array}$ & $\begin{array}{l}\text { population (settlement and infrastructure impact) } \\
\text { immigration (infrastructure impact -urban vs. rural) }\end{array}$ \\
\hline Ecological & pollution problems, local biota \\
\hline Sustainability & community action, projects, and sustainable practices \\
\hline Climate & temperature, precipitation, wind, humidity \\
\hline
\end{tabular}

\subsubsection{Identify Curriculum Expectations Related to Place-Based EE.}

The curriculum expectations containing the themes outlined in Section 3.2.3.1, were further analyzed for the presence of direct and indirect place-based EE content. As previously mentioned, direct content requires the topic to be taught while indirect content provides an opportunity for it to be taught.

An overview of the place-based categorization process is outlined in Figure 5. Curriculum expectations were initially placed into one of three groups based on the scale of the study. This was established using a key word search described in the rationale column of Table 6 . The initial three groups are as follows:

A. Place-based EE - if the scale of study was regional/municipal or smaller and specific to a student's own region,

B. Indirect place-based EE - if the scale of study was regional/municipal or smaller but did not specify a student's own region, and

C. Neither - If the scale of study was not regional/municipal or smaller. Within category A, place-based EE, curriculum expectations were further categorized according to the prescriptiveness of their environmental focus. This was a less concrete process than the first because an environmental focus is difficult to define with key words. In general, expectations with an indirect focus tended to occur "in" the environment but were not necessarily, "for" and "about" it. Examples have been provided in Table 6 to provide clarity. These subcategories are as follows: 
i. Direct place-based EE - if it had a clear environmental focus, and

ii. Indirect place-based EE - if provided an opportunity to study the environment but did not require it.

The overall outcome is that curriculum expectations were classified into three categories:

1) Direct place-based $E E(\mathrm{Ai})$ - if they were local studies with a clear environmental focus,

2) Indirect place-based EE (B, Aii) - if they provided an opportunity for local study OR if they were local studies without a clear environmental focus, and

3) Neither (C) - if they were not local studies.

See Table 6 below for a summary of the major categories, the key word rationale behind their initial grouping, and curriculum expectation examples.

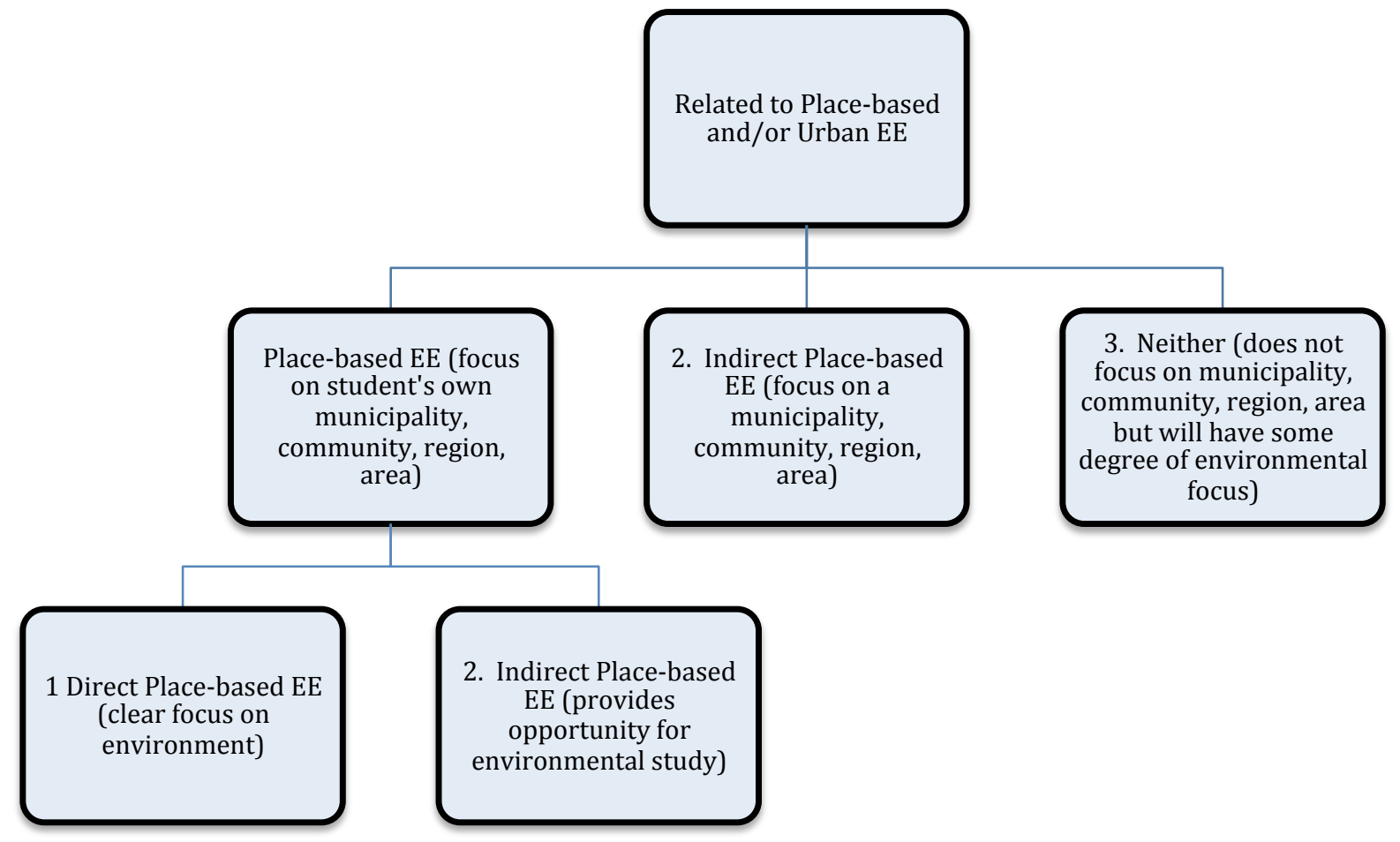

Figure 5: Place-Based EE Categorization Process 
Table 6: Place-Based EE Classification, Rationale, and Examples

\begin{tabular}{|c|c|c|}
\hline Categorization & Rationale & Examples \\
\hline $\begin{array}{l}\text { 2. (B) Indirect Place- } \\
\text { based }\end{array}$ & $\begin{array}{l}\text { Environmental and } \\
\text { substitutable for place- } \\
\text { based } \\
\text { KEY WORDS - "a } \\
\text { community", } \\
\text { "communities", "a region", } \\
\text { "a city" }\end{array}$ & $\begin{array}{l}\text { "What would the costs and benefits of } \\
\text { developing a wind and/or solar farm be } \\
\text { for your community, a community in } \\
\text { southern Alberta, or another location of } \\
\text { your choice?"-CGC1D (C2.4)* } \\
\text { Analyse the impact of a selected project } \\
\text { on a community- CGC1P (E2.4)* }\end{array}$ \\
\hline $\begin{array}{l}\text { 2. (Aii) Indirect Place- } \\
\text { based }\end{array}$ & $\begin{array}{l}\text { Substitutable for } \\
\text { environmental and place- } \\
\text { based } \\
\text { KEY WORDS -"your } \\
\text { community", "their } \\
\text { community", "area in } \\
\text { which you live", "area in } \\
\text { which they live", "your } \\
\text { region", "local" }\end{array}$ & $\begin{array}{l}\text { Describe the major demographic } \\
\text { characteristics of present-day Canada } \\
\text { and compare them to those of your } \\
\text { community or local area. - CGC1P } \\
(\mathrm{D} 3.2)^{*} \\
\text { Describe a variety of ways in which they } \\
\text { could make a civic contribution at the } \\
\text { local, national, and/or global level- } \\
\text { CHV2O (C1.2)* }\end{array}$ \\
\hline $\begin{array}{l}\text { 1. (Ai) Direct Place- } \\
\text { based }\end{array}$ & $\begin{array}{l}\text { Environmental and place- } \\
\text { based } \\
\text { KEY WORDS -"your } \\
\text { community", "their } \\
\text { community", "area in } \\
\text { which you live", "area in } \\
\text { which they live", "your } \\
\text { region", "local" }\end{array}$ & $\begin{array}{l}\text { Describe different types of land use } \\
\text { within their community and explain } \\
\text { reasons for their location. - CGC1P } \\
\text { (E3.1)* } \\
\text { Assess the effectiveness of a local } \\
\text { initiative of personal interest that seeks } \\
\text { to ensure the sustainability of a } \\
\text { terrestrial or aquatic ecosystem - } \\
\text { SNC1P (B1.2)* }\end{array}$ \\
\hline 3. (C) Neither & $\begin{array}{l}\text { Environmental but not } \\
\text { place-based }\end{array}$ & $\begin{array}{l}\text { Analyse ways in which human actions } \\
\text { have increased or decreased the } \\
\text { production of greenhouse gases. SNC2P } \\
(\mathrm{D} 1.2)^{*} \\
\text { Assess the social and environmental } \\
\text { impact of the production or use of a } \\
\text { common element or simple compound. } \\
\text { - SNC1P }(\mathrm{C} 1.2)^{*}\end{array}$ \\
\hline
\end{tabular}

* The code in brackets helps to locate an expectation within Appendix A and the Ontario curriculum documents. The letter corresponds to the strand, the first number corresponds to the overall expectation and the second number corresponds to the specific expectation. 
Furthermore, any direct expectations with place-based EE content present in only the examples and sample questions were treated as "indirect place-based EE". The purpose of examples, and sample questions is to suggest options for the expectation. In other words, they provide possible avenues for study but do not require it.

\subsubsection{Identify Curriculum Expectations Related to Urban EE}

A similar categorization process was performed for urban EE. The curriculum expectations containing the themes outlined in Section 3.2.3.1, were further analyzed for direct and indirect urban EE content.

An overview of the urban categorization process is outlined in Figure 6. A curriculum expectation was categorized as having a direct relation to urban EE if it contained key words such as "urban", "municipal" or "city", which are used as synonyms for the word city. They also fell in this category if they contained key words that are characteristic of cities such as "high population density", "high rise apartment buildings" and "public transit". Also falling under the direct relation category, were expectations within three of the six themes derived from Godfrey's (2010) article on the convergence of urban and environmental studies. The themes of Planning, Systems, Politics (municipal) were selected because they are characteristic of the complex structure and governance of cities. To be classified as having an indirect relationship to urban EE, Godfrey's (2010) remaining three themes of Ecology (general anthropogenic factors) and Immigration and Settlement (access to resources), and Sociogeography (population trends, social and economic systems) had to be present. These themes are more widespread and although equally important features of cities, they are also commonly applied to other settings or fields. See Table 7 below for a summary of the major categories, the key word and thematic rationale behind their grouping, and curriculum expectation examples. The categorization system used for urban EE was less robust than the method used for place-based EE because it used more themes and fewer key words. As such, there were occasional exceptions to the rules due to tone or emphasis in wording. An 
example of such an exception is "Explain the influence of Canada's natural characteristics on the spatial distribution of its population - CGC1P (B2.2)" which was classified as Sociogeographic but directly related to urban EE. This expectation clearly looks at the impact of the environment on population. Alternatively, the majority of Sociogeographic expectations such as "Identify factors that influence the demographic characteristics of settlements across Canada - CGC1D (D3.2)" were not as overt in their link to the environment. These factors could also include jobs, infrastructure, and training.

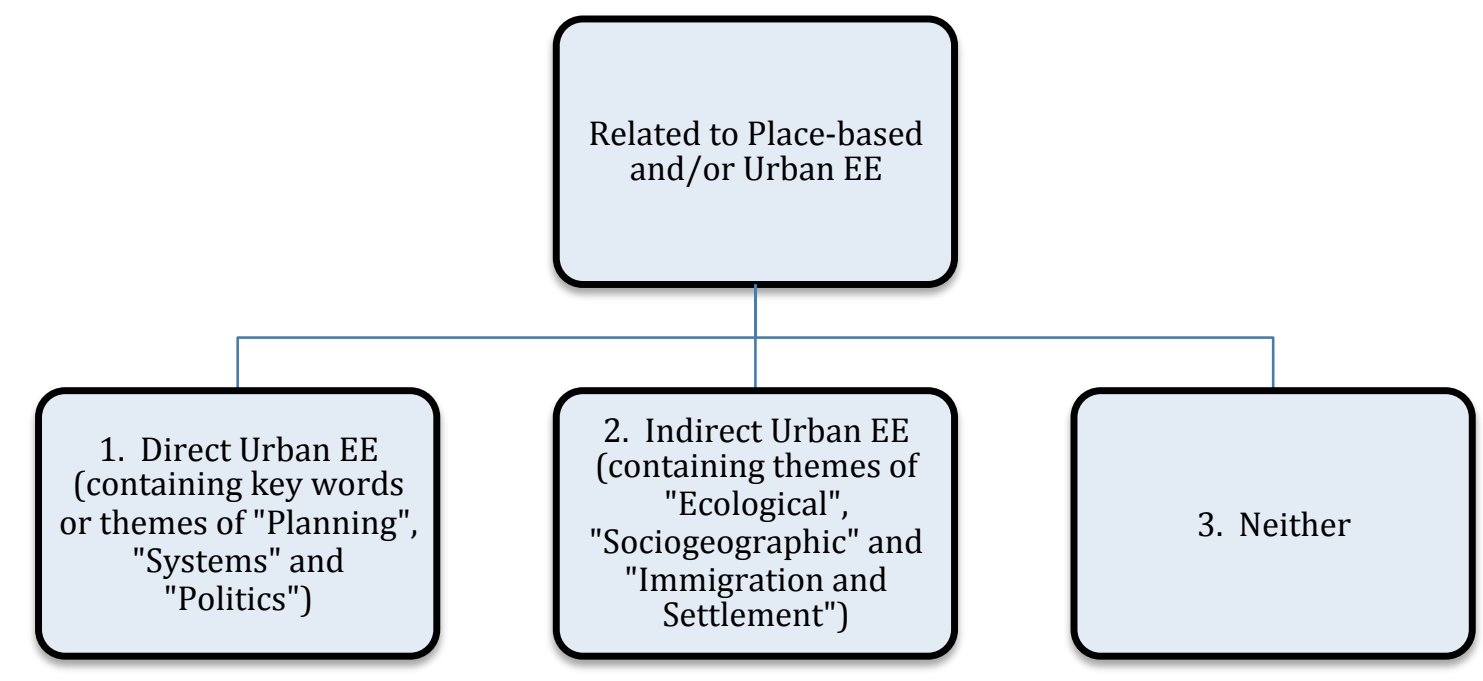

Figure 6: Urban EE Categorization Process

As with the place-based method, any direct expectations with urban EE only present in the examples and sample questions were treated as "indirect urban EE" as their purpose is to provide examples and/or suggest options for the expectation itself. 
Table 7: Urban EE Classification, Rationale, and Examples

\begin{tabular}{|c|c|c|}
\hline Categorization & Rationale & Examples \\
\hline Direct Urban EE & $\begin{array}{l}\text { KEY WORDS - "urban", } \\
\text { "municipal", "city", "high } \\
\text { population density", "high rise } \\
\text { apartment buildings", "public } \\
\text { transit" } \\
\text { and/or } \\
\text { THEMES: } \\
\text { Systems (waste, transportation, } \\
\text { food, water) } \\
\text { Planning (land use analysis) } \\
\text { Politics (municipal governance) }\end{array}$ & $\begin{array}{l}\text { Assess the impact of urban growth on } \\
\text { natural systems - CGC1D (E2.1) } \\
\text { Explain, with reference to issues of civic } \\
\text { importance, the roles and } \\
\text { responsibilities of different levels of } \\
\text { government in Canada - CHV2O (B2.2) } \\
\text { Explain how changes in land use can } \\
\text { affect the growth or decline of different } \\
\text { parts of a community - CGC1P (E2.3) }\end{array}$ \\
\hline Indirect Urban EE & $\begin{array}{l}\text { THEMES: } \\
\text { Ecological (general } \\
\text { anthropogenic factors such as } \\
\text { paving over land, vehicle } \\
\text { emissions), } \\
\text { Sociogeographic (social or } \\
\text { economic systems, general } \\
\text { analysis of population trends) } \\
\text { Immigration and Settlement } \\
\text { (urban vs. rural, geographic } \\
\text { population patterns, } \\
\text { infrastructure impact) }\end{array}$ & $\begin{array}{l}\text { Analyse the effect of factors related to } \\
\text { human activity on terrestrial or aquatic } \\
\text { ecosystems by interpreting data and } \\
\text { generating graphs - SNC1P (B2.5) } \\
\text { Identify factors that influence the } \\
\text { demographic characteristics of } \\
\text { settlements across Canada - CGC1D } \\
\text { (D3.2) } \\
\text { Explain how human activities in their } \\
\text { local region can have an impact on } \\
\text { natural processes - CGC1P (B1.4) }\end{array}$ \\
\hline Neither & & $\begin{array}{l}\text { Classify the climate of their local region } \\
\text { using various tools or systems (e.g., } \\
\text { Ecoregions of Canada, bioclimate } \\
\text { profiles), and compare their region to } \\
\text { other regions in Ontario, Canada, and } \\
\text { the world - SNC2D (D2.8) }\end{array}$ \\
\hline
\end{tabular}

\subsubsection{Requirement of Field Study/Outdoor Education}

This purpose of this section is to identify urban and/or place-based EE curriculum that requires field study or outdoor education. This is one of the key characteristics of place-based education described in the literature review. To be 
classified as requiring field study, the expectation does not have to occur outside of school property or even be outdoors. An example of indoor field study on school property could be asking students to conduct a school waste inventory to assess recycling practices. In field studies, students must leave the four walls of their classroom and have first-hand experiences studying the "field".

\subsubsection{Identify Curriculum Expectations that are Participatory with Action Outcomes}

The purpose of this section is to identify urban and/or place-based EE expectations that involve a real world issue and require a product or action that is useful outside the classroom. This can take the form of community or school action (i.e. the greening of school grounds), writing letters to politicians regarding environmental concerns, and creating local land use improvement plans.

\subsection{Enrolment in EE Elective Courses and Course Offerings}

The province of Ontario has published secondary curriculum for hundreds of courses in various subjects, grades, and types. The majority of these courses are found in senior grades (11 and 12) and are designated electives because they are not an O.S.S.D. requirement. Graduate studies do not provide sufficient time and resources to perform a curriculum review of every elective. As such, course titles were reviewed for potential links to any of the eight urban and placebased themes and a list of relevant courses was compiled. Student enrollment and course offering data for these courses was obtained from the Ministry of Education for the 2012-2013 school year. This was the most recent year of data available, officially three years after the publication of the policy framework, Acting Today, Shaping Tomorrow (OME, 2009). The Ontario School Information System [ONSIS] was used to provide context to these values by providing data on the total number of public secondary schools in Ontario and the number of students registered in each grade 9-12 for the 2012 school year. Using both the Ministry and ONSIS data sets, the percentage of students in each grade pursuing the electives of interest could be calculated. The data analysis can be found in 
Section 4.3 of Analysis and Discussion. It provides some insights into the continuity of urban and place-based EE throughout the secondary school years. 


\section{ANALYSIS AND DISCUSSION}

The analysis and discussion section of this document follows the same sequence as the Methods (Section 3). It begins with a summary of observations from the EEW, followed by the curriculum review of mandatory courses, and finishes with the enrollment data analysis.

\subsection{Summary of Observations from the Education Experts' Workshop: Implementing 2007 Bondar Report's Intended Outcomes in 2015}

The summary of observations from the EEW in the sections that follow provide insight into the barriers experienced by educators and administrators in implementing place-based and urban EE. They have been clustered into four groups. The first discusses how well policy is translated to educators, the second describes systemic barriers to implementing EE in classrooms, the third looks at barriers to outdoor education, and the last discusses additional barriers to implementing EE.

\subsubsection{Policy Awareness and Shared Vision}

As a result of the Bondar Report, documents such as Acting Today, Shaping Tomorrow (OME, 2009), defining the province's new EE policies and strategies were developed. These documents are described in Section 2.2.2. Participants at EEW expressed their concerns about disparities in their awareness of these documents and the vision described within them. Exposure ranged from not knowing of their existence, particularly in the case of new teachers, to general familiarity, observed with administrators. With the exception of Ministry representatives, and EE academics, few stakeholder groups present at the workshop referred to the documents on a regular basis.

This raises the concern that the vision of EE developed by the Ministry of Education has not been adequately translated to those who work most closely with students. Chowdhury's (2015) graduate study at OISE examining the implementation of EE in Ontario also recommended raising teacher awareness of policy documents. Pre-service efforts such as DEEPER will likely address many 
of these issues for new teachers (Ontario Institute for Studies in Education, 2013) but exposure for other stakeholder groups would have to be provided through alternate means.

One of the most significant changes that came from the Bondar Report's recommendations was integrating $E E$ into the curriculum as a whole (OME, 2009). Teachers at EEW acknowledged that they work most closely with curriculum documents and have far more familiarity with them than policy and strategy documents. They also discussed their efforts to follow the curriculum as closely as possible while also using their professional judgment to adapt it to meet the needs of their students. One of the barriers to implementing EE that was perceived by the participants of EEW, was an overcrowded curriculum. Participants commented that the result of an overcrowded curriculum was the inability to meet all course requirements or having to "rush through them". This barrier has been well documented by other parties (Tan \& Pedretti, 2010). Moreover, some teachers stated that the EE curriculum lacked "absolute wording", providing opportunities to incorporate EE but not insisting that they be pursued. They commented that with an already overcrowded curriculum and the time constraints placed upon teachers, opportunities to incorporate EE were being overlooked in favor of other initiatives such as literacy and numeracy. Administrators echoed these statements with their own crowded policy domains consisting of areas such as wellness and STEM (science, technology, engineering, and mathematics).

Definitive wording requires that the environment be studied rather than suggesting the environment as a possible avenue for study. Assessing the extent to which this type of wording is present in curriculum documents is one of the objectives of this study. A lack of clear direction and strong wording in Ontario's integrated model runs the risk of perpetuating the marginalization of EE to the field of science. This is a pitfall for the integration model, a "shallow integration" (Pardy, 2010) reminiscent of Premier Mike Harris's "patchwork approach" (Puk \& Behm, 2003). Without clear implementation to ensure continuity and progression (UNESCO, 1978; Neil, 1994), EE loses its place as an 
overarching theme.

In an integrated approach, all stakeholders share the responsibility of EE and they must be fully cognizant of their role in promoting it. This constitutes a truly shared vision. Stakeholders must have good working knowledge of EE policy goals and the goals themselves should be explicit in curriculum policy documents. If too many of the expectations related to EE are ambiguous and their importance is not otherwise emphasized, then EE becomes optional rather than essential.

\subsubsection{Barriers to the Implementation of EE}

Even with a shared vision and deep awareness of the integrated model, participants identified problems in implementing successful EE in schools. Having insufficient "opportunities to communicate with peers" and other stakeholders in both "structured and unstructured formats" was raised as a concern.

There are countless EE resources available to teachers online and in textbooks; however, place-based EE in particular, needs to be personalized. Place-based EE is rooted in communities and their regional environments and is an important component of EE. It requires teachers to have professional development (PD) time to locally develop or personalize resources so that they are region specific. Furthermore, to effectively engage students, EE must be contemporary and continuously updated to address timely issues. The interdisciplinary nature of EE also necessitates collaboration between secondary school departments, which can be accomplished through PD. This is particularly true of urban EE, which frequently involves multiple fields of study (i.e. political, social, economic, and ecological).

Participants at EEW also identified the issue of subject teachers "opting out" of EE because they lack expertise or comfort with the material and relegate it to its traditional science vehicle. As a more structured form of PD, the creation of additional qualification courses in EE, and DEEPER has improved teacher confidence and ability. These initiatives target new and interested teachers but 
do not address the majority of experienced teachers. More system-wide structures need to be in place to promote EE if all educators are to prioritize learning.

Discussions at the EEW also revealed that "no teacher truly identified as an environmental educator" regardless of their involvement in senior environmental electives. Their explanation for this was that in schools offering these electives, there was often only one section and therefore no community of teachers with which to collaborate.

The availability and enrollment in electives containing urban and place-based $E E$ is examined by this study. These factors could also contribute to a sparse community of EE educators if the courses are not widely offered or not well attended. Subject association groups in EE do exist and help to connect teachers of these courses but they are still relatively new and growing in size.

According to the participants of EEW, much of the EE programming that takes place in schools is a direct result of volunteer efforts on the part of teachers, students and administrators. Consequently, stakeholders agreed that it is applied inconsistently across the province with a broad range in the actions taking place at each school. Administrators, in particular, acknowledged the importance of recognizing volunteer efforts to maintain enthusiasm and a positive climate of change. Widespread examples of participatory programming discussed at the workshop included the Ontario EcoSchools certification program and Ontario Envirothon. ${ }^{3}$ Representatives from EcoSchools at the EEW acknowledged that the considerable amount of work required by individual teachers acted as a deterrent from participation in the program.

Some boards in the province of Ontario have taken the route of making

\footnotetext{
3 Ontario EcoSchools is a non-profit education and certification program for K-12 schools in the province (Ontario EcoSchools, 2016). The certification process (from bronze to platinum) is based on teamwork and leadership, energy conservation, waste minimization, school ground greening, curriculum, and environmental stewardship (Ontario EcoSchools, 2016). There are currently over 4000 schools with Ontario EcoSchools certification in the province (Ontario EcoSchools, 2016). Envirothon is a five-person team competition involving interactive field study and workshops in the areas of forests, wildlife, soils and aquatic ecosystems (Forests Ontario, 2016). It requires a registration fee and is currently attended by over 200 schools and 10000 students in the province of Ontario (Forests Ontario, 2016).
} 
participation in EcoSchools mandatory. This is an interesting approach with great potential to improve EE in schools but it cannot be seen as a one-stop shop as its focus is on facility operations and participation over curriculum. Participants at the EEW raised the issue of having one of these areas overshadow the other. Without clear instruction, the weight that school boards and schools place on each of these areas is subjective. Ontario EcoSchools has the potential to develop into a more comprehensive platform if key stakeholders choose to make it so but in the interim, schools must be wary of using certification as justification for inaction in EE curriculum development.

Elementary and secondary schools operate very differently from each other and often differ in size. Principals at the EEW recognized the potential advantage of smaller elementary schools with fewer administrators in realizing environmental goals. Large secondary schools posed more problems for implementing school wide efforts.

There is currently very little in Acting Today, Shaping Tomorrow (OME, 2009) with regards to EE programming in secondary schools. The policy framework mandates the creation of environmental plans and frameworks at the school and board level but does not specify what they should contain (OME, 2009). The approach that is taken by each board and school depends greatly on the interest, passion, and resources available to individuals (Pedretti et al., 2012). One of the objectives of this study is to assess the extent to which participatory and action outcomes are present in the urban and place-based EE curriculum. If this type of programming is deeply embedded in the curriculum, then reliance on inconsistent voluntary effort is no longer necessary.

Not directly related to this study but interesting to note were the solutions to concerns of EE program and PD financing. Participants applauded local solutions such as the Toronto District School Board's (TDSB) Environmental Legacy Fund, which raises money through the sale of carbon credits and solar panel generated energy. They also acknowledged the need for local solutions to be recognized and advertised as model examples of supports to provincial funding. 


\subsubsection{Outdoor Education}

Participants at the EEW acknowledged that schools need to forge lasting relationships with their communities and explore simple ways to get outside. Some of the ways that were discussed included making use of school grounds and community sites, inviting community experts into the classroom, bringing in specialized kits or local samples, using public transit or walking to sites, streamlining field trip paperwork, identifying subsides, and using virtual tours. Participants suggested that once these avenues have been identified for a specific school, they need to be fostered so that they become habitual.

Among the organizations contributing to the discussion at EEW were the Ontario Science Centre, the Ontario Clean Water Agency, and Evergreen. Most of the external organizations present provided off site locations with unique programming, non-traditional learning for students, and professional development opportunities for teachers. While many of their programs were well attended, they worked diligently to forge curriculum connections and tried to offer field trip subsidies to remove funding barriers. Some of the obstacles that they faced involved; overcoming safety concerns; increasing teacher, student, and parent comfort levels with the outdoors; and, shifting the focus of outdoor education from recreational to promoting environmental literacy. They expressed the importance of teacher engagement on field trips to motivate and inspire students. To make visits more meaningful to students and promote attendance in their programs, many organizations were trying to provide pre, during, and post visit resources, develop a narrative for yearly visits, and offer teacher PD. Teachers recognized the value in field trips but missed out on opportunities due to the time constraints of an overcrowded curriculum, the complexities of field trip logistics and paperwork, concerns over safety and comfort levels, accessibility (particularly in the case of urban schools), and funding.

The concerns raised by EEW participants of overcrowded curriculum, access to the outdoors (Tan \& Pedretti, 2010), and comfort levels (Ontario Institute for Studies in Education, 2013) are well documented by other parties. One of the objectives of this study is to assess the extent to which field studies are 
embedded in the urban and place-based curriculum. Field studies are an important component of place-based EE and EE as a whole because they foster "personal concern" (Neil, 1994). If field study requirements are widespread, then

the province can focus its efforts on overcoming logistical barriers. As mentioned by the participants of EEW, field studies do not need to be costly.

\subsubsection{Other Concerns}

With representatives from a variety of schools with very different student bodies, some felt that "academic" schools pursued environmental initiatives more. In these settings it was speculated that: students were better at navigating their own environmental pursuits; parents were more likely to be educated about environmental issues; and school communities were better able to advocate for environmental change. Teachers involved in the Model Schools for Inner Cities (Toronto District School Board [TDSB], 2011) program with the Toronto District School Board were present at EEW. This program focuses on schools where large numbers of students live in poverty. It provides additional resources to allow students "to participate fully and equally in their schools and communities" and "improves student achievement through focused supports and opportunities" (TDSB, 2011). Teachers at EEW who were part of this program discussed the need for a concerted effort in inner city schools to make the environment a priority and empower students to shape their communities.

One of the recommendations of the Bondar Report was to map EE progression through the curriculum and provide opportunities for EE in senior grades. An important component of this study is to examine the enrollment in and availability of urban and place-based EE electives. This will provide some insight into the continuity of EE throughout the high school years. It will also be interesting to note if these data agree with the statements made by EEW participants regarding "academic" students. Data have been grouped by course type to see if there are significant differences in enrollment or availability. The curriculum review component of this study has also been grouped by course type and can provide inform the same concerns. 


\subsection{Curriculum Review}

The curriculum review of the mandatory courses identified in Section 3.2.1., has been summarized and discussed in this section of the document. It is organized as per the Methods Section 3.2.3., starting with raw counts of expectations containing urban and place-based EE themes. The expectations containing urban and place-based EE content were then analyzed for direct and indirect wording to determine if they provided opportunities for study or required it. They were also reviewed to determine the total number and range of urban and place-based field study and participatory/action outcome requirements. Discussion in this section focuses of the frequency of raw counts within various grades, subjects, and course types.

\subsubsection{Urban and/or Place-Based EE Content by Theme}

A total of 675 expectations were reviewed for urban and place-based EE content. Of these, 124 contained themes related to urban or place-based EE. This accounts for $\sim 18 \%$ of all expectations reviewed. Considering that these courses are not stand-alone EE courses, the frequency with which these themes are present is substantial. This aligns well with the Bondar Report's curriculum recommendations in Section 2.2.3 to "Ensure that all secondary students are exposed to EE though its substantial presence in compulsory Grade 9 Geography, Grade 9 and 10 Science, and Grade 10 Civics expectations" (OME, 2007b). The 124 expectations and their categorization can be found in Appendix A (OME, 2014). Table 8 provides a summary of the 124 expectations listing raw counts by course. 
Table 8: Urban and/or Place-based EE Content by Course

\begin{tabular}{|c|c|c|c|c|c|c|}
\hline $\begin{array}{l}\text { 岁 } \\
\text { 足 }\end{array}$ & $\begin{array}{c}\text { COURSE } \\
\text { CODE }\end{array}$ & COURSE TITLE & 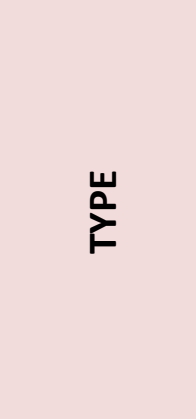 & 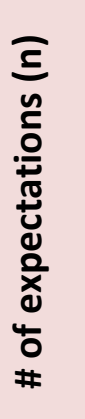 & 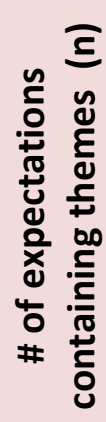 & 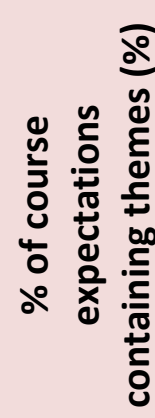 \\
\hline 9 & CGC1D & $\begin{array}{l}\text { Issues in } \\
\text { Canadian } \\
\text { Geography }\end{array}$ & Academic & 70 & 31 & 44 \\
\hline 9 & CGC1P & $\begin{array}{l}\text { Issues in } \\
\text { Canadian } \\
\text { Geography }\end{array}$ & Applied & 68 & 28 & 41 \\
\hline 10 & CHV2O & $\begin{array}{l}\text { Civics and } \\
\text { Citizenship }\end{array}$ & $\begin{array}{l}\text { Open } * \\
\text { half } \\
\text { course }\end{array}$ & 45 & 12 & 27 \\
\hline 10 & GLC2O & Career Studies & Open & 42 & 2 & 4.8 \\
\hline 9 & SNC1D & Science & Academic & 90 & 11 & 12 \\
\hline 9 & SNC1P & Science & Applied & 86 & 13 & 15 \\
\hline 10 & SNC2D & Science & Academic & 95 & 5 & 5.3 \\
\hline 10 & SNC2P & Science & Applied & 89 & 1 & 1.1 \\
\hline 11 & SVN3E & $\begin{array}{c}\text { Environmental } \\
\text { Science }\end{array}$ & Workplace & 90 & 21 & 23 \\
\hline & \multicolumn{3}{|c|}{ TOTALS } & 675 & 124 & \\
\hline & \multicolumn{3}{|c|}{$\%$ of TOTAL } & $\mathrm{N} / \mathrm{A}$ & 100 & \\
\hline
\end{tabular}

Table 9 lists raw counts by grade. It should be noted that Environmental Science (SVN3E) is the only grade 11 course and is not designated as a mandatory course therefore it has been omitted from Table 9. The table shows that urban and place-based content is more prevalent in grade $9-26 \%$ over grade $10-7.4 \%$. This is not surprising given that students take Issues in Canadian Geography (CGC1D/CGC1P) in Grade 9. As seen in Table 8, CGC1D - $44 \%$ and CGC1P - $41 \%$ had the greatest percentage of urban and placebased EE expectations. The difference seen between coverage in grade 9 and 
10 should be noted for the purpose of ensuring progression and continuity. O.S.S.D. requirements are designed with a broad range of mandatory courses assigned to grades 9 and 10 and more choice and electives assigned to the senior years as students develop their post-secondary plans. It is interesting to note that the only subjects that students are compelled to take over multiple years are English and Mathematics (OME, 2014). These subjects are present in the curriculum as discrete courses, but literacy and numeracy are considered to be overarching themes and the responsibility of all subject teachers (OME, 2014). EE has not been treated in the same manner as literacy and numeracy. It has been infused in the curriculum but does not have its own compulsory courses. Urban and place-based EE becomes more widespread and less evenly distributed in the senior years because of increased course options and the wide range of EE content within them. Policy documents recognize this shift in senior years when they ensure EE's "substantial presence" in grade 9 and 10 courses and provide "opportunities" for EE in senior years (OME, 2007b). With most students receiving their urban and place-based EE in grade 9 and 10, it should be a prevalent feature of these years.

Table 9: Urban and/or Place-based EE Content by Grade

\begin{tabular}{|c|c|c|c|}
\hline $\begin{array}{c}\text { 㞺 } \\
\text { 灾 }\end{array}$ & $\begin{array}{c}\text { \# of } \\
\text { expectations } \\
\text { (n) }\end{array}$ & $\begin{array}{c}\text { \# of expectations } \\
\text { containing themes } \\
\text { (n) }\end{array}$ & $\begin{array}{c}\text { \% of grade } \\
\text { expectations } \\
\text { containing themes } \\
(\%)\end{array}$ \\
\hline 9 & 314 & 83 & 26 \\
\hline 10 & 271 & 20 & 7.4 \\
\hline
\end{tabular}

With respect to theme distribution, summarized in Table 10, most of the 124 expectations fell under the category of Planning $-27 \%$ or Ecological $-44 \%$. The Sciences, SNC1D - 11 of 11 , SNC1P - 12 of 13, SNC2D - 3 of 5 , and SNC2P 1 of 1 , all had a clear Ecological focus. Most expectations were not multidisciplinary falling only under one theme. This is apparent when row totals are compared to number of expectations containing themes (i.e. SNC1D contained 11 relevant expectations with a total of 13 themes assigned to them 
Table 10: Urban and/or Place-based EE Content by Theme

\begin{tabular}{|c|c|c|c|c|c|c|c|c|c|c|c|c|}
\hline \multirow[b]{2}{*}{$\begin{array}{l}\text { 岁 } \\
\text { 足 }\end{array}$} & \multirow[b]{2}{*}{ 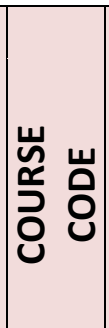 } & \multirow[b]{2}{*}{$\begin{array}{c}\text { COURSE } \\
\text { TITLE }\end{array}$} & \multirow[b]{2}{*}{$\stackrel{u}{\stackrel{u}{\gtrless}}$} & \multirow[b]{2}{*}{$\begin{array}{l}\text { \# of } \\
\text { expecta- } \\
\text { tions } \\
\text { containing } \\
\text { themes }(n)\end{array}$} & \multicolumn{8}{|c|}{ Number of expectations related to: } \\
\hline & & & & & 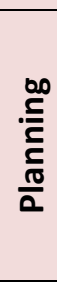 & 苨 & 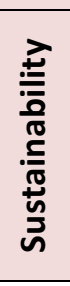 & $\begin{array}{l}\stackrel{0}{ \pm} \\
\stackrel{\Xi}{U}\end{array}$ & $\frac{\tilde{U}}{\underline{\underline{\underline{O}}}}$ & 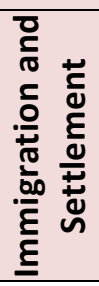 & 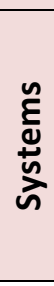 & 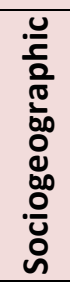 \\
\hline 9 & 号 & $\begin{array}{l}\text { Issues in } \\
\text { Canadian } \\
\text { Geography }\end{array}$ & $\begin{array}{l}\frac{u}{E} \\
\frac{0}{0} \\
\frac{0}{0} \\
\frac{0}{4}\end{array}$ & 31 & 13 & 3 & 1 & 3 & 0 & 8 & 12 & 4 \\
\hline 9 & ড্ডি & $\begin{array}{l}\text { Issues in } \\
\text { Canadian } \\
\text { Geography }\end{array}$ & $\frac{\frac{0}{0}}{\frac{0}{2}}$ & 28 & 13 & 5 & 1 & 1 & 0 & 5 & 4 & 7 \\
\hline 10 & 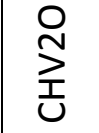 & $\begin{array}{l}\text { Civics and } \\
\text { Citizenship }\end{array}$ & ठั & 12 & 5 & 0 & 4 & 0 & 5 & 0 & 1 & 0 \\
\hline 10 & 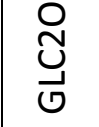 & $\begin{array}{l}\text { Career } \\
\text { Studies }\end{array}$ & $\begin{array}{l}\frac{1}{0} \\
\text { o̊ }\end{array}$ & 2 & 0 & 0 & 2 & 0 & 0 & 0 & 0 & 0 \\
\hline 9 & 号 & Science & $\begin{array}{l}\frac{u}{\varepsilon} \\
\frac{d}{d} \\
\frac{0}{0} \\
\frac{U}{4}\end{array}$ & 11 & 1 & 11 & 0 & 0 & 1 & 0 & 0 & 0 \\
\hline 9 & $\sum_{\text {in }}^{0}$ & Science & $\frac{\text { 을 }}{\frac{0}{0}}$ & 13 & 0 & 12 & 1 & 0 & 0 & 0 & 0 & 0 \\
\hline 10 & ¿ิ & Science & $\begin{array}{l}\frac{u}{E} \\
\frac{0}{0} \\
\frac{0}{0} \\
\frac{0}{4}\end{array}$ & 5 & 1 & 3 & 0 & 1 & 1 & 1 & 0 & 0 \\
\hline 10 & 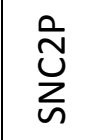 & Science & $\frac{\frac{0}{0}}{\frac{0}{2}}$ & 1 & 0 & 1 & 1 & 0 & 0 & 0 & 0 & 0 \\
\hline 11 & $\sum_{n}^{m}$ & $\begin{array}{c}\text { Environme- } \\
\text { ntal } \\
\text { Science }\end{array}$ & $\begin{array}{l}0 \\
\frac{u}{0} \\
\frac{\pi}{2} \\
\frac{i}{\vdots} \\
3\end{array}$ & 21 & 0 & 19 & 0 & 0 & 2 & 0 & 1 & 0 \\
\hline & & TOTALS & & 124 & 33 & 54 & 10 & 5 & 9 & 14 & 18 & 11 \\
\hline & & $\%$ of 124 & & 100 & 27 & 44 & 8.1 & 4.0 & 7.3 & 11 & 15 & 8.9 \\
\hline
\end{tabular}


corresponding to a ratio 1.2). Issues in Canadian Geography (CGC1D/CGC1P) tended to be slightly more multidisciplinary covering multiple themes (i.e. CGC1D contained 31 relevant expectations with a total of 44 themes assigned to them corresponding to a ratio of 1.4). The theme of Planning was most prevalent in Issues in Canadian Geography CGC1D - 13 of 31, and Issues in Canadian Geography CGC1P - 13 of 38 with some content in Systems, Sociogeography, and Immigration \& Settlement. Civics and Citizenship (CHV2O) was evenly distributed between Planning -5 of 12 , Sustainability -4 of 12 , and Politics -5 of 12 and had an expectation to theme ratio of 1.3. The analysis shows that specific subjects gravitate towards their own set of themes and are not particularly multidisciplinary in their approach to urban and place-based EE.

Table 11 contains expectations grouped according to the major grade 9 and 10 pathways. There does not appear to be a large difference between the two pathways. A deeper comparison can be found by comparing academic and applied courses of the same grade and subject. For example, Science SNC1D $12 \%$ and Science SNC1P - 15\% in Table 8. This type of comparison also shows no remarkable differences between pathways in grade 9 and 10. Nevertheless, a student that chooses to take Environmental Science SVN3E - 23\% instead of Science SNC2D $-5.3 \%$ or Science SNC2P $-1.1 \%$ as their second mandatory science credit would have more exposure to urban and place-based EE. This is a rare event, as seen in Section 4.3, which shows that only $4 \%$ of grade 11 students chose to take Environmental Science (SVN3E).

The concerns expressed by some of the participants of EEW regarding "academic" students being more involved in EE is not significantly reflected in this data analysis although there are slightly more expectations seen the academic stream. Their observations may also have been rooted in mandatory or voluntary programming differences between streams rather that curriculum differences. 
Table 11: Urban and/or Place-based EE Content by Course Type

\begin{tabular}{|c|c|c|c|}
\hline 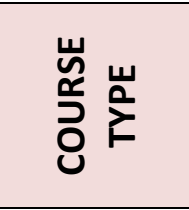 & $\begin{array}{c}\text { \# of } \\
\text { expectations (n) }\end{array}$ & $\begin{array}{c}\text { \# of expectations } \\
\text { containing } \\
\text { themes (n) }\end{array}$ & $\begin{array}{c}\% \text { of course type } \\
\text { expectations } \\
\text { containing themes } \\
(\%)\end{array}$ \\
\hline Academic & 255 & 47 & 18 \\
\hline Applied & 243 & 42 & 17 \\
\hline
\end{tabular}

\subsubsection{Urban EE Content Summary}

Tables 12 and 13 provide a summary of expectations within the 124 that were related to urban EE. The expectations have been grouped by course and classified as either direct or indirect in their relation to urban EE. As seen in Table 12, of the 124 curriculum expectations related to urban and place-based EE, 22 of them had a direct relation to urban EE. This corresponds to $18 \%$ of the 124 expectations but only $3.3 \%$ of the total 675 expectations reviewed. All but one was found in Issues in Canadian Geography. The percentage of course content in Issues in Canadian Geography that was directly related to urban EE was CGC1D $-17 \%$ and CGC1P - 13\%. The majority of expectations were related to the themes of Planning or Systems and they were found within the "Livable Communities" strand of Issues in Canadian Geography (OME, 2014).

Slightly more direct urban expectations were present in the academic stream than the applied stream. Again, these differences are small but it is possible that the themes of Systems, characteristic of complex urban environments, may be better suited to the "academic" stream, which tends to combine topics and study them in more depth. Modifications can be made to make this theme more accessible to "applied" learners. Like the combined urban and place-based results of Section 4.2.1, these data show a minor correlation to the observations made regarding "academic" learners at EEW. 
Table 12: Direct Urban EE Content Summary

\begin{tabular}{|c|c|c|c|c|c|c|}
\hline GRADE & COURSE TITLE & TYPE & $\begin{array}{c}\text { COURSE } \\
\text { CODE }\end{array}$ & $\begin{array}{c}\text { Total \# } \\
\text { of } \\
\text { expecta- } \\
\text { tions in } \\
\text { course } \\
\text { (n) }\end{array}$ & $\begin{array}{c}\text { Expecta- } \\
\text { tions } \\
\text { directly } \\
\text { related to } \\
\text { urban EE } \\
\text { (n) }\end{array}$ & $\begin{array}{c}\text { of Course } \\
\text { expecta- } \\
\text { tions } \\
\text { directly } \\
\text { related to } \\
\text { urban EE } \\
\text { (\%) }\end{array}$ \\
\hline 9 & $\begin{array}{c}\text { Issues in } \\
\text { Canadian } \\
\text { Geography }\end{array}$ & Academic & CGC1D & 70 & 12 & 17 \\
\hline 9 & $\begin{array}{c}\text { Issues in } \\
\text { Canadian } \\
\text { Geography }\end{array}$ & Applied & CGC1P & 68 & 9 & 13 \\
\hline 10 & $\begin{array}{c}\text { Civics and } \\
\text { Citizenship }\end{array}$ & $\begin{array}{c}\text { Open } * \\
\text { half course }\end{array}$ & CHV2O & 45 & 1 & 2.2 \\
\hline 10 & Career Studies & Open & GLC2O & 42 & 0 & 0 \\
\hline 9 & Science & Academic & SNC1D & 90 & 0 & 0 \\
\hline 9 & Science & Applied & SNC1P & 86 & 0 & 0 \\
\hline 10 & Science & Academic & SNC2D & 95 & 0 & 0 \\
\hline 10 & Science & Applied & SNC2P & 89 & 0 & 0 \\
\hline$* 11$ & $\begin{array}{c}\text { Environmental } \\
\text { Science }\end{array}$ & Workplace & SVN3E & 90 & 0 & 0 \\
\hline
\end{tabular}

* included because prerequisites are either 9 academic or applied science

As seen in Table 13, there were a total of 49 expectations with an indirect relation to urban EE. This corresponds to $40 \%$ of the 124 expectations and $7.3 \%$ of the total 675 expectations reviewed. They were found in Issues in Canadian Geography CGC1D -13\% and Issues in Canadian Geography CGC1P - 12\%, Science SNC1D -10\% and Science SNC1P - 8.1\%, and Environmental Science, SVN3E -18\%. Within Issues in Canadian Geography (CGC1D/CGC1P) the majority of expectations were found in the "Changing Populations" strand and were related to Immigration and Settlement. In Science (SNC1D/SNC1P) the expectations were found in the biology strand titled "Sustainable Ecosystems" and had an Ecological focus. Environmental Science (SVN3E) saw expectations in a few different strands but the majority had an Ecological focus. Again, this 
speaks to the compartmentalization of secondary school subjects, which is at odds with the multidisciplinary field of EE (Smith, 2007).

In summary, virtually all of the direct and indirect urban EE content was found in the grade 9 curriculum. The lack of urban EE content at the grade 10 level. was seen earlier in the combined urban and place-based EE results of Section 4.2.1. This trend is more apparent in the field of urban EE where older students may be better able to grasp its complexity.

Table 13: Indirect Urban EE Content Summary

\begin{tabular}{|c|c|c|c|c|c|c|}
\hline GRADE & COURSE TITLE & TYPE & $\begin{array}{l}\text { COURSE } \\
\text { CODE }\end{array}$ & $\begin{array}{c}\text { Total \# } \\
\text { of } \\
\text { expec- } \\
\text { tations } \\
\text { in } \\
\text { course } \\
\text { (n) }\end{array}$ & $\begin{array}{l}\text { Expecta- } \\
\text { tions } \\
\text { indirectly } \\
\text { related to } \\
\text { urban EE } \\
\text { (n) }\end{array}$ & $\begin{array}{c}\text { \% of } \\
\text { Course } \\
\text { expecta- } \\
\text { tions } \\
\text { indirectly } \\
\text { related to } \\
\text { urban EE } \\
(\%)\end{array}$ \\
\hline 9 & $\begin{array}{l}\text { Issues in } \\
\text { Canadian } \\
\text { Geography }\end{array}$ & Academic & CGC1D & 70 & 9 & 13 \\
\hline 9 & $\begin{array}{l}\text { Issues in } \\
\text { Canadian } \\
\text { Geography }\end{array}$ & Applied & CGC1P & 68 & 8 & 12 \\
\hline 10 & $\begin{array}{l}\text { Civics and } \\
\text { Citizenship }\end{array}$ & $\begin{array}{l}\text { Open } * \text { half } \\
\text { course }\end{array}$ & $\mathrm{CHV} 2 \mathrm{O}$ & 45 & 0 & 0 \\
\hline 10 & Career Studies & Open & GLC2O & 42 & 0 & 0 \\
\hline 9 & Science & Academic & SNC1D & 90 & 9 & 10 \\
\hline 9 & Science & Applied & SNC1P & 86 & 7 & 8.1 \\
\hline 10 & Science & Academic & SNC2D & 95 & 0 & 0 \\
\hline 10 & Science & Applied & SNC2P & 89 & 0 & 0 \\
\hline$* 11$ & $\begin{array}{c}\text { Environmental } \\
\text { Science }\end{array}$ & Workplace & SVN3E & 90 & 16 & 18 \\
\hline & & & TOTALS & 633 & 49 & \\
\hline
\end{tabular}

Of the 675 expectations studied, $11 \%$ had urban EE content with only $3.3 \%$ constituting direct content. The $7.3 \%$ having an indirect link to urban EE dealt with general pollution and population characteristics (i.e. vehicle emissions, age distribution) rather than specifically urban issues or environmental/geographic 
population characteristics (i.e. public transit systems, population density). By definition, these indirect expectations have a weak link to urban EE. Furthermore, if they are found in the examples or sample questions sections of an expectation, which many of the are, they must compete with an overcrowded curriculum, apathy, and lack of resources (Tan \& Pedretti, 2010) as well as the feelings of unpreparedness and lack of policy awareness expressed by the participants at EEW. Considering that these courses form the basis of urban EE for the majority of high school students, the prevalence of direct expectations does not seem particularly high.

\subsubsection{Place-Based EE Content Summary}

Tables 14 and 15 provide a summary of expectations that were related to place-based EE. The expectations have been grouped by course and classified as either direct or indirect in their relation to place-based EE. As seen in Table 14 , of the 124 curriculum expectations related to urban and place-based EE, 15 of them had a direct relation to place-based EE. This corresponds to $12 \%$ of the 124 expectation but only $2.2 \%$ of the total 675 expectations reviewed. As with urban EE, most were found in Issues in Grade 9 Geography CGC1P -12\%; however, it is interesting to note that no expectations were found in the academic stream, CGC1D $-0 \%$. The majority of expectations were situated in the "Livable Communities" strand and focused on the theme of Planning. One possible explanation for this result is that applied course are designed to be more "practical", "concrete" and "hands-on" and therefore make better use of placebased EE, which is rooted in the familiar and accessible (OME, 2014). They also lend themselves well to the applied concept of Planning. Academic courses, on the other hand, tend to focus more on theory and abstract concepts (OME, 2014). The value place-based EE should not be absent from the academic stream because it helps to build "personal concern" (Neil, 1994) and relevance. The only other course with significant direct place-based content was Environmental Science SVN3E $-4.4 \%$. The majority of expectations were related to Ecology. As with the trends in urban EE, the subject silos of secondary 
schools compartmentalize EE themes (Smith, 2007), few expectations are present in grade 10, and the less frequented Environmental Science (SVN3E) pathway contains more coverage of place-based EE than the traditional grade 10 Science route.

Table 14: Direct Place-Based EE Content Summary

\begin{tabular}{|c|c|c|c|c|c|c|}
\hline GRADE & COURSE TITLE & TYPE & $\begin{array}{l}\text { COURSE } \\
\text { CODE }\end{array}$ & $\begin{array}{l}\text { Total \# } \\
\text { of } \\
\text { expecta- } \\
\text { tions in } \\
\text { course } \\
\text { (n) }\end{array}$ & $\begin{array}{l}\text { Expecta- } \\
\text { tions } \\
\text { directly } \\
\text { related to } \\
\text { place- } \\
\text { based EE } \\
\text { (n) }\end{array}$ & $\begin{array}{l}\text { \% of Course } \\
\text { expecta- } \\
\text { tions } \\
\text { directly } \\
\text { related to } \\
\text { place-based } \\
\text { EE (\%) }\end{array}$ \\
\hline 9 & $\begin{array}{l}\text { Issues in } \\
\text { Canadian } \\
\text { Geography }\end{array}$ & Academic & CGC1D & 70 & 0 & 0 \\
\hline 9 & $\begin{array}{l}\text { Issues in } \\
\text { Canadian } \\
\text { Geography }\end{array}$ & Applied & CGC1P & 68 & 8 & 12 \\
\hline 10 & $\begin{array}{l}\text { Civics and } \\
\text { Citizenship }\end{array}$ & $\begin{array}{l}\text { Open } \\
\text { half } \\
\text { course }\end{array}$ & CHV2O & 45 & 0 & 0 \\
\hline 10 & Career Studies & Open & GLC2O & 42 & 0 & 0 \\
\hline 9 & Science & Academic & SNC1D & 90 & 0 & 0 \\
\hline 9 & Science & Applied & SNC1P & 86 & 2 & 2.3 \\
\hline 10 & Science & Academic & SNC2D & 95 & 1 & 1.1 \\
\hline 10 & Science & Applied & SNC2P & 89 & 0 & 0 \\
\hline$* 11$ & $\begin{array}{c}\text { Environmental } \\
\text { Science }\end{array}$ & Workplace & SVN3E & 90 & 4 & 4.4 \\
\hline & & & TOTALS & 633 & 15 & \\
\hline
\end{tabular}

As seen in Table 15, there were a total of 18 expectations with an indirect relation to place-based EE. This corresponds to $15 \%$ of the 124 expectations and $2.7 \%$ of the total 675 expectations reviewed. They are spread throughout the curriculum with the majority in Issues in Canadian Geography CGC1D $-5.7 \%$ and Issues in Canadian Geography CGC1P $-8.8 \%$, Civics and Citizenship, CHV2O $-8.9 \%$, and Career Studies, GLC2O $-4.8 \%$. There were slightly more 
expectations present in the applied stream.

It is interesting to note that very few place-based expectations are located in the Science curriculum. Perhaps this speaks to the juxtaposition between conventional science and EE pedagogies observed by Steele (2011). Some of the impediments to place-based EE that he raises include overemphasis on "the scientific knowledge base that is deemed necessary for students" rather than application of those skills to a real-life context, and "the influence of textbooks" which are based on a provincially standardized curriculum and tend not to include community-specific study (Steele, 2011).

Table 15: Indirect Place-Based EE Content Summary

\begin{tabular}{|c|c|c|c|c|c|c|}
\hline GRADE & $\begin{array}{l}\text { COURSE } \\
\text { TITLE }\end{array}$ & TYPE & $\begin{array}{c}\text { COURSE } \\
\text { CODE }\end{array}$ & $\begin{array}{c}\text { Total \# } \\
\text { of } \\
\text { expecta- } \\
\text { tions in } \\
\text { course } \\
\text { (n) }\end{array}$ & $\begin{array}{l}\text { Expecta- } \\
\text { tions } \\
\text { indirectly } \\
\text { related to } \\
\text { place- } \\
\text { based EE } \\
\text { (n) }\end{array}$ & $\begin{array}{c}\% \text { of Course } \\
\text { expecta- } \\
\text { tions } \\
\text { indirectly } \\
\text { related to } \\
\text { place-based } \\
\text { EE (\%) }\end{array}$ \\
\hline 9 & $\begin{array}{l}\text { Issues in } \\
\text { Canadian } \\
\text { Geography }\end{array}$ & Academic & CGC1D & 70 & 4 & 5.7 \\
\hline 9 & $\begin{array}{l}\text { Issues in } \\
\text { Canadian } \\
\text { Geography }\end{array}$ & Applied & CGC1P & 68 & 6 & 8.8 \\
\hline 10 & $\begin{array}{l}\text { Civics and } \\
\text { Citizenship }\end{array}$ & $\begin{array}{c}\text { Open }{ }^{*} \\
\text { half course }\end{array}$ & CHV2O & 45 & 4 & 8.9 \\
\hline 10 & $\begin{array}{l}\text { Career } \\
\text { Studies }\end{array}$ & Open & GLC2O & 42 & 2 & 4.8 \\
\hline 9 & Science & Academic & SNC1D & 90 & 0 & 0 \\
\hline 9 & Science & Applied & SNC1P & 86 & 0 & 0 \\
\hline 10 & Science & Academic & SNC2D & 95 & 1 & 1.1 \\
\hline 10 & Science & Applied & SNC2P & 89 & 0 & 0 \\
\hline$* 11$ & $\begin{array}{c}\text { Environment } \\
\text { al Science }\end{array}$ & Workplace & SVN3E & 90 & 1 & 1.1 \\
\hline & & & TOTALS & 633 & 18 & \\
\hline
\end{tabular}

Of the 675 expectations studied, a total of $4.9 \%$ had some place-based EE 
content. This is significantly lower than the percentage of expectations containing urban EE. An indirect link to place-based EE was found in $2.2 \%$ of them, meaning that they provided an opportunity for local study or were local studies without a clear environmental focus. Indirect place-based EE content faces the same obstacles as urban EE, observed by Tan and Pedretti (2010), but also has its own unique set of impediments, which include safety concerns and access to the outdoors. The participants of EEW discussed many of these and ways in which they could be overcome through simple excursions, making use of school grounds, and forging lasting community partnerships.

\subsubsection{Involving Field Study and Action Outcomes}

Table 16 provides a summary of expectations that were related to field study or required an action outcome. The expectations have been grouped by course. As seen in Table 16, only six expectations involving regional field study were found in the curriculum. Five of the six were found in Environmental Science (SVN3E). These expectations required students to conduct field studies on the water quality, soil quality, and biodiversity as well as conduct a waste audit of their home or school. One expectation was also found in Science (SNC1P) requiring students to graph and interpret electricity consumption data from meters at home or in the community. With the majority of field study found in the Environmental Science (SVN3E) a small proportion of students are reaping its benefits.

Participatory expectations with action outcomes were even more rare in the mandatory curriculum with only two in Civics and Citizenship (CHV2O) providing students with the opportunity to communicate their local environmental ideas or data to an intended audience. These two expectations were not directly related to urban and place-based EE as the environment was listed as one of many examples. Curriculum recommendation \#7 in Section 2.2.2 made by the Bondar report makes the suggestion to "Identify and support opportunities to engage students in environmental action projects within the current Civics course". There are currently very few expectations within Civics and Citizenship (CHV2O) 
course that allow for this kind of expansion.

Table 16: Field Study and Action Outcome Content Summary

\begin{tabular}{|c|c|c|c|c|c|c|}
\hline GRADE & COURSE TITLE & TYPE & $\begin{array}{c}\text { COURSE } \\
\text { CODE }\end{array}$ & $\begin{array}{c}\text { Total \# of } \\
\text { expecta- } \\
\text { tions in } \\
\text { course } \\
\text { (n) }\end{array}$ & $\begin{array}{c}\text { Expecta- } \\
\text { tions } \\
\text { involving } \\
\text { regional } \\
\text { field } \\
\text { study (n) }\end{array}$ & $\begin{array}{c}\text { Expecta- } \\
\text { tions } \\
\text { involving } \\
\text { participation } \\
\text { with action } \\
\text { outcomes (n) }\end{array}$ \\
\hline 9 & $\begin{array}{c}\text { Issues in } \\
\text { Canadian } \\
\text { Geography }\end{array}$ & Academic & CGC1D & 70 & 0 & 0 \\
\hline 9 & $\begin{array}{c}\text { Issues in } \\
\text { Canadian } \\
\text { Geography }\end{array}$ & Applied & CGC1P & 68 & 0 & 0 \\
\hline 10 & $\begin{array}{c}\text { Civics and } \\
\text { Citizenship }\end{array}$ & $\begin{array}{c}\text { Open } * \\
\text { half course }\end{array}$ & CHV2O & 45 & 0 & 2 \\
\hline 10 & Career Studies & Open & GLC2O & 42 & 0 & 0 \\
\hline 9 & Science & Academic & SNC1D & 90 & 0 & 0 \\
\hline 9 & Science & Applied & SNC1P & 86 & 1 & 0 \\
\hline 10 & Science & Academic & SNC2D & 95 & 0 & 0 \\
\hline 10 & Science & Applied & SNC2P & 89 & 0 & 0 \\
\hline$* 11$ & $\begin{array}{c}\text { Environmental } \\
\text { Science }\end{array}$ & Workplace & SVN3E & 90 & 5 & 0 \\
\hline & & & & & & \\
\hline
\end{tabular}

"Action competence" (Barratt \& Hacking, 2011) is an important goal of successful EE, which requires experience and knowledge. Part of this experience should be acquired in secondary schools if students are to become active citizens with the tools necessary to enact positive change in their environment. Local field study and action outcomes can also be viewed as measures of community involvement. Community connections are vital to "community health and development" and "student well-being" (Sanders, 2003).

Alternative education models incorporate long periods of field study by immersing students in nature for multiple days. For many, this can be a unique and rewarding experience that deepens their connection to the environment. In the province of Ontario, field studies and action outcomes appear to be sparse in the 
mandatory curriculum.

\subsection{Enrolment in EE Elective Courses and Course Availability}

A curriculum review of urban and place-based EE content in mandatory subjects was undertaken. The vast majority of these courses are found in grades 9 and 10. A curriculum review was not performed on elective courses related to urban and place-based EE; however, statistics on course availability and enrolment can provide some insight into the effectiveness of EE progression plans and integration into the curriculum. As per the recommendations made by the Bondar Report, students should be offered opportunities to pursue EE in the senior grades (grades 11 and 12) to provide continuity and reinforce the importance of EE (OME, 2007b).

Table 17 provides a basis for reference for secondary enrolment by grade in the 2012-2013 school year. As of 2012-2013, there were 3,978 elementary and

Table 17: Secondary Enrolment 2012-2013 (OnSIS, 2013)

\begin{tabular}{|c|c|c|c|}
\hline Grade & $\begin{array}{c}\text { Number of Students } \\
\text { in Public Schools }\end{array}$ & $\begin{array}{c}\text { Number of Students in } \\
\text { Roman Catholic Schools }\end{array}$ & Total \\
\hline Grade 9* & 100,856 & 49,341 & 150,197 \\
\hline Grade 10 & 103,040 & 50,318 & 153,358 \\
\hline Grade 11 & 108,061 & 51,849 & 159,910 \\
\hline Grade 12 & 153,408 & 67,724 & 221,132 \\
\hline Total & $\mathbf{6 3 8 , 2 2 0}$ & $\mathbf{2 1 9 , 2 3 2}$ & $\mathbf{6 8 4 , 5 9 7}$ \\
\hline
\end{tabular}

Data includes public and Roman Catholic schools and school authorities. Data excludes private schools, publicly funded hospital and provincial schools, care, treatment and correctional facilities, summer, night and adult continuing education day schools. Data are based on headcount of students.

"Data includes students designated as "Pre-Grade 9".

913 secondary schools in the province of Ontario (OnSIS, 2013). Since these data are specific to one school year, they do not depict any trend in course offerings and enrolment.

Using Table 17, and enrollment and course availability data provided by the Ministry of Education, Tables 19-24 were generated. They are grouped by grade and contain enrollment as a percentage of the overall number of students 
in that grade. They also contain course availability as a percentage of the total number of secondary schools in Ontario. All of the courses in these tables were selected based on their relevance to urban and place-based EE themes. Given the time constraints and limited resources of graduate study, a full-scale curriculum review could not be performed on all electives.

\subsubsection{Grade 9 and 10 Electives}

Tables 18 and 19 provide a summary of grade 9 and 10 electives related to urban and place-based EE. Table 18 lists the courses selected for analysis and identifies their link to urban and place-based EE themes. Table 19 summarizes course availability and enrollment. In grade 9, the only elective course offered was Food and Nutrition (HFN1O). Although 19\% of schools offered the course, only $4.5 \%$ of grade 9 students were registered in the course. This is not surprising as there is little opportunity to take electives at the grade 9 level. Most

Table 18: Grade 9 and 10 Elective Courses with Urban and/or Place-Based EE Content

\begin{tabular}{|c|c|c|l|}
\hline $\begin{array}{c}\text { Course } \\
\text { Code }\end{array}$ & Course Name & Grade & \multicolumn{1}{c|}{ Urban and/or Place-Based EE Theme(s) } \\
\hline HFN10 & $\begin{array}{c}\text { Food and } \\
\text { Nutrition }\end{array}$ & Grade 9 & $\begin{array}{l}\text { Planning (regional food production, urban } \\
\text { agriculture) } \\
\text { Climate (regional food production) } \\
\text { Ecological (regional food production) } \\
\text { Systems (food distribution) }\end{array}$ \\
\hline HFN2O & $\begin{array}{c}\text { Food and } \\
\text { Nutrition }\end{array}$ & Grade 10 & $\begin{array}{l}\text { Planning (regional food production, urban } \\
\text { agriculture) } \\
\text { Climate (regional food production) } \\
\text { Ecological (regional food production) } \\
\text { Systems (food distribution) }\end{array}$ \\
\hline THJ2O & $\begin{array}{c}\text { Green } \\
\text { Industries }\end{array}$ & Grade 10 & $\begin{array}{l}\text { Politics (green incentives) } \\
\text { Sustainability (resource availability) }\end{array}$ \\
\hline TTJ2O & $\begin{array}{c}\text { Transportation } \\
\text { Technology }\end{array}$ & Grade 10 & $\begin{array}{l}\text { Planning (land use) } \\
\text { Systems (transportation) }\end{array}$ \\
\hline
\end{tabular}

students have room for only one true elective course in this grade because in 
addition to mandatory courses in Mathematics, English, Science, and Geography they choose to fulfill their Arts, Health and Physical Education, and French as a Second Language requirements (see Table 2 in Section 3.2.1).

Table 19: Grade 9 and 10 Course Availability and Enrolment

\begin{tabular}{|c|c|c|c|c|c|c|c|}
\hline $\begin{array}{l}\text { Course } \\
\text { Code }\end{array}$ & Course Name & Grade & $\begin{array}{l}\text { Course } \\
\text { Type }\end{array}$ & $\begin{array}{c}\text { \# of } \\
\text { Schools } \\
\text { Offering } \\
\text { Elective }\end{array}$ & $\begin{array}{c}\text { \% of } \\
\text { Schools } \\
\text { Offering } \\
\text { Elective }\end{array}$ & $\begin{array}{c}\text { \# of } \\
\text { Students } \\
\text { Taking } \\
\text { Course }\end{array}$ & $\begin{array}{c}\text { \% of } \\
\text { Students } \\
\text { Taking } \\
\text { Course* }\end{array}$ \\
\hline HFN1O & $\begin{array}{l}\text { Food and } \\
\text { Nutrition }\end{array}$ & Grade 9 & $\begin{array}{c}\text { Open } \\
\text { (Grade } 9 \text { - } \\
12 \text { level) }\end{array}$ & 170 & 19 & 6686 & 4.5 \\
\hline HFN2O & $\begin{array}{l}\text { Food and } \\
\text { Nutrition }\end{array}$ & Grade 10 & $\begin{array}{c}\text { Open } \\
\text { (Grade } 9 \text { - } \\
12 \text { level) }\end{array}$ & 503 & 55 & 24963 & 16 \\
\hline THJ2O & $\begin{array}{c}\text { Green } \\
\text { Industries }\end{array}$ & Grade 10 & $\begin{array}{c}\text { Open } \\
\text { (Grade } 9 \text { - } \\
12 \text { level) }\end{array}$ & 68 & 7.4 & 1254 & 0.8 \\
\hline TTJ2O & $\begin{array}{c}\text { Transportation } \\
\text { Technology }\end{array}$ & Grade 10 & $\begin{array}{c}\text { Open } \\
\text { (Grade } 9 \text { - } \\
12 \text { level) }\end{array}$ & 534 & 58 & 17403 & 11 \\
\hline
\end{tabular}

* \% of students in grade

In grade 10 , there is more selection with respect to course offerings, partially due to these increased opportunities to pursue electives. If Arts, Health and Physical Education, and French as a Second Language requirements are met in grade 9 , the only mandatory courses are History, Civics and Citizenship (0.5 credits), Careers ( 0.5 credits), Mathematics, English and Science. In grade 10, $55 \%$ of schools offered Food and Nutrition (HFN2O) with $16 \%$ of grade 10 students taking the course, and $58 \%$ of schools offered Transportation Technology (TTJ2O) with $11 \%$ of students taking the course. Only $7.4 \%$ of secondary schools in Ontario offered Green Industries (THJ2O) with $0.8 \%$ of students taking the course. Green Industries (THJ2O) contains the most obvious link to urban and place-based EE. Many reasons can contribute to poor availability of a course. These include a lack of expertise in teachers, lack of interest by students, timetabling conflicts, poor perceived need for future 
endeavors, or a combination of these factors. It is difficult to pinpoint the cause without more information. All of the electives courses offered in grades 9 and 10 are open, which means that they are appropriate for a broad range of students and do not have prerequisites. The curriculum review in Section 4.2 showed that most urban and place-based EE is found in grade 9. Options to further studies with grade 10 electives become even more important with content lacking in the mandatory grade 10 courses.

\subsubsection{Grade 11 Electives}

Tables 20 and 21 follow a similar format to Table 18 and 19 but focus on grade 11 electives. In Grade 11, students must think more carefully about their "exit plan" post-secondary school. There are four major destinations that students pursue: university, college, skilled trade and apprenticeship programs, and workplace. As seen in the course type column in Tables 20 and 21, courses exist in every pathway for students interested in continuing EE in grade 11 . This aligns well with the Bondar Report curriculum recommendation \#8 in Section 2.2.2 of this document, "Ensure that secondary students have the opportunity to take at least one additional course with an environmental focus during their high school program (preferable in Grade 11 to maintain continuity)" (OME, 2007b). The percentage of schools offering these courses is less than $25 \%$, with the exception of Understanding Canadian Law (CLU3M) which is offered in $79 \%$ of schools and taken by $20 \%$ of students, Environmental Science (SVN3M) which is offered in $29 \%$ of schools and taken by $3.0 \%$ of students, and Travel and Tourism: A Geographic Perspective (CGG3O) which is offered in $62 \%$ of schools and taken by $9 \%$ of students. The latter two courses contain the most obvious links to urban and place-based EE and despite the fact that availability is high, enrollment is low. A second group of courses with availability in the range of 10 $25 \%$ consist of Housing and Home Design, HLS3O - 20\%, Understanding Canadian Law, CLU3E - 18\%, and World History since 1900: Global and Regional Interactions, $\mathrm{CHT} 3 \mathrm{O}-14 \%$. The last course has the most obvious link to place-based EE and also has the highest enrolment at 10\%. The final group 
experiences the lowest availability $(<10 \%)$ and enrolment $(<1 \%)$ and consists of Politics in Action (CPC3O) and Regional Geography (CGD3M).

Table 20: Grade 11 Elective Courses with Urban and/or Place-Based EE Content

\begin{tabular}{|c|c|c|c|}
\hline $\begin{array}{l}\text { Course } \\
\text { Code }\end{array}$ & Course Name & Grade & Urban and/or Place-Based EE Theme(s) \\
\hline HLS3O & $\begin{array}{l}\text { Housing and Home } \\
\text { Design }\end{array}$ & Gr.11 & $\begin{array}{l}\text { Planning (land use and zoning) } \\
\text { Sociogeographic (population distribution) } \\
\text { Politics (affordable housing) } \\
\text { Sustainability (materials, energy) }\end{array}$ \\
\hline SVN3E $* *$ & $\begin{array}{l}\text { Environmental } \\
\text { Science }\end{array}$ & Gr. 11 & $\begin{array}{l}\text { Ecological (pollution, habitat restoration and } \\
\text { protection) } \\
\text { Politics (responsibilities, jurisdictions) }\end{array}$ \\
\hline SVN3M & $\begin{array}{l}\text { Environmental } \\
\text { Science }\end{array}$ & Gr. 11 & $\begin{array}{l}\text { Ecological (pollution, habitat restoration and } \\
\text { protection) } \\
\text { Politics (responsibilities, jurisdictions) }\end{array}$ \\
\hline CLU3E & $\begin{array}{l}\text { Understanding } \\
\text { Canadian Law in } \\
\text { Everyday Life }\end{array}$ & Gr. 11 & $\begin{array}{l}\text { Politics (environmental responsibilities, } \\
\text { governance) }\end{array}$ \\
\hline CLU3M & $\begin{array}{l}\text { Understanding } \\
\text { Canadian Law }\end{array}$ & Gr. 11 & $\begin{array}{l}\text { Politics (environmental responsibilities, } \\
\text { governance) }\end{array}$ \\
\hline СРСЗО & $\begin{array}{l}\text { Politics in Action: } \\
\text { Making Change }\end{array}$ & Gr. 11 & $\begin{array}{l}\text { Politics (environmental responsibilities, } \\
\text { governance) } \\
\text { Sustainability (community action) }\end{array}$ \\
\hline CGD3M & Regional Geography & Gr. 11 & $\begin{array}{l}\text { Planning (land use, zoning) } \\
\text { Sociogeographic (population distribution) } \\
\text { Immigration and Settlement (growth, access to } \\
\text { resources) }\end{array}$ \\
\hline CHT3O & $\begin{array}{l}\text { World History since } \\
\text { 1900: Global and } \\
\text { Regional Interactions }\end{array}$ & Gr. 11 & $\begin{array}{l}\text { Planning (land use, zoning) } \\
\text { Sociogeographic (population distribution) } \\
\text { Immigration and Settlement (growth, access to } \\
\text { resources) } \\
\text { Ecological (pollution, habitats) }\end{array}$ \\
\hline CGG30 & $\begin{array}{l}\text { Travel and Tourism: } \\
\text { A Geographic } \\
\text { Perspective }\end{array}$ & Gr. 11 & $\begin{array}{l}\text { Sociogeographic (population distribution) } \\
\text { Climate (characteristics of region) } \\
\text { Systems (accessibility) }\end{array}$ \\
\hline
\end{tabular}


Table 21: Grade 11 Course Availability and Enrolment

\begin{tabular}{|c|c|c|c|c|c|c|c|}
\hline $\begin{array}{l}\text { Course } \\
\text { Code }\end{array}$ & Course Name & Grade & Course Type & $\begin{array}{c}\text { \# of } \\
\text { Schools } \\
\text { Offering } \\
\text { Elective }\end{array}$ & $\begin{array}{l}\text { \% of } \\
\text { Schools } \\
\text { Offering } \\
\text { Elective }\end{array}$ & $\begin{array}{c}\text { \# of } \\
\text { Students } \\
\text { Taking } \\
\text { Course }\end{array}$ & $\begin{array}{c}\% \text { of } \\
\text { Students } \\
\text { Taking } \\
\text { Course* }\end{array}$ \\
\hline HLS3O & $\begin{array}{l}\text { Housing and } \\
\text { Home Design }\end{array}$ & Gr.11 & $\begin{array}{c}\text { Open (Grade } \\
9-12 \text { level) }\end{array}$ & 187 & 20 & 2047 & 1.3 \\
\hline $\begin{array}{c}\text { SVN3E } \\
* *\end{array}$ & $\begin{array}{l}\text { Environmental } \\
\text { Science }\end{array}$ & Gr. 11 & $\begin{array}{c}\text { Workplace } \\
\text { Preparation } \\
\text { (Grade } 11 \text { \& } \\
12 \text { level) }\end{array}$ & 390 & 43 & 5827 & 3.6 \\
\hline SVN3M & $\begin{array}{l}\text { Environmental } \\
\text { Science }\end{array}$ & Gr. 11 & $\begin{array}{l}\text { University/ } \\
\text { College } \\
\text { Preparation } \\
\text { (Grade } 11 \& \\
12 \text { level) }\end{array}$ & 263 & 29 & 4760 & 3.0 \\
\hline CLU3E & $\begin{array}{l}\text { Understanding } \\
\text { Canadian Law in } \\
\text { Everyday Life }\end{array}$ & Gr. 11 & $\begin{array}{c}\text { Workplace } \\
\text { Preparation } \\
\text { (Grade } 11 \& \\
12 \text { level) }\end{array}$ & 167 & 18 & 2047 & 1.3 \\
\hline CLU3M & $\begin{array}{l}\text { Understanding } \\
\text { Canadian Law }\end{array}$ & Gr. 11 & $\begin{array}{l}\text { University/ } \\
\text { College } \\
\text { Preparation } \\
\text { (Grade } 11 \text { \& } \\
12 \text { level) }\end{array}$ & 722 & 79 & 32427 & 20 \\
\hline СРС3О & $\begin{array}{c}\text { Politics in } \\
\text { Action: Making } \\
\text { Change }\end{array}$ & Gr. 11 & $\begin{array}{c}\text { Open (Grade } \\
9-12 \text { level) }\end{array}$ & 12 & 1.3 & 144 & 0.1 \\
\hline CGD3M & $\begin{array}{l}\text { Regional } \\
\text { Geography }\end{array}$ & Gr. 11 & $\begin{array}{l}\text { University/ } \\
\text { College } \\
\text { Preparation } \\
\text { (Grade } 11 \& \\
12 \text { level) }\end{array}$ & 5 & 0.5 & 130 & 0.1 \\
\hline СНT3O & $\begin{array}{l}\text { World History } \\
\text { since 1900: } \\
\text { Global and } \\
\text { Regional } \\
\text { Interactions }\end{array}$ & Gr. 11 & $\begin{array}{c}\text { Open (Grade } \\
9-12 \text { level) }\end{array}$ & 131 & 14 & 16263 & 10 \\
\hline CGG30 & $\begin{array}{l}\text { Travel and } \\
\text { Tourism: A } \\
\text { Geographic } \\
\text { Perspective }\end{array}$ & Gr. 11 & $\begin{array}{c}\text { Open (Grade } \\
9-12 \text { level) }\end{array}$ & 565 & 62 & 14523 & 9.1 \\
\hline
\end{tabular}

*\% of students in grade

** not considered to be true elective because it can count as the second mandatory science requirement (with grade 9 academic/applied science as a prerequisite) 
As previously discussed in Section 2.2.2, the Environmental Science courses offered at the Workplace (SVN3E) and University/College (SVN3M) level received considerable attention when they were removed in 1998 under the Harris government (Puk \& Behm, 2003). With these course reinstated, we see $43 \%$ of schools offering Environmental Science (SVN3E) and 3.6\% of students taking the course and $29 \%$ of schools offering Environmental Science (SVN3M) and $3.0 \%$ of students taking the course. It should be noted, as explained in Section 3.2.1, that only the SVN3M is considered to be a true elective as the SVN3E can count as a student's second mandatory science requirement with only grade 9 academic or applied science as a prerequisite. Availability and enrollment data for the Environmental Science courses is quite telling, as these courses were once stand-alone courses, representing EE in the curriculum. Their availability is widespread but enrollment appears to be low considering the attention given to them. Participants at EEW cited poor availability of Environmental Science courses within a school as a barrier to collaboration and identifying as an environmental educator. It is difficult to substantiate these statements using the data provided because there is no information on how many sections of each course are offered within a given school.

\subsubsection{Grade 12 Electives}

Similar to grade 11, Tables 22 and 23 show a greater number of courses related to urban and place-based EE themes than grade 9 and 10. Greater course availability is reflective of increased freedom to take more electives in senior years. Again, the course type column indicates that courses exist in every pathway but there is only one course offered at the workplace level. The percentage of schools offering the following courses is greater than $25 \%$ for Environment and Resource Management, CGR4M - 27\%, World Issues: A Geographic Analysis, CGW4U - 61\%, Food and Nutrition Sciences, HFA4M $40 \%$, and Challenge and Change in Society, HSB4M - 58\%. The proportion of grade 12 students taking these courses ranged from $\sim 2.6 \%$ to $11 \%$. The highest enrolment was seen in Challenge and Change in Society (HSB4M). 
Table 22: Grade 12 Elective Courses with Urban and/or Place-Based EE Content

\begin{tabular}{|c|c|c|c|}
\hline $\begin{array}{l}\text { Course } \\
\text { Code }\end{array}$ & Course Name & Grade & Urban and/or Place-Based EE Theme(s) \\
\hline CGO4M & $\begin{array}{c}\text { Spatial } \\
\text { Technologies in } \\
\text { Action }\end{array}$ & Gr. 12 & $\begin{array}{l}\text { Planning (land use and zoning) } \\
\text { Sociogeographic (population distribution) } \\
\text { Immigration and Settlement (growth, access to } \\
\text { resources) }\end{array}$ \\
\hline CGR4E & $\begin{array}{l}\text { Living in a } \\
\text { Sustainable World }\end{array}$ & Gr. 12 & $\begin{array}{l}\text { Planning (land use) } \\
\text { Systems (linear vs. cyclical) } \\
\text { Ecological (pollution, habitat protection) } \\
\text { Politics (government incentives and policy) }\end{array}$ \\
\hline CGR4M & $\begin{array}{c}\text { Environment and } \\
\text { Resource } \\
\text { Management }\end{array}$ & Gr. 12 & $\begin{array}{l}\text { Systems (materials, energy) } \\
\text { Planning (land use) } \\
\text { Politics (policy, jurisdiction) } \\
\text { Sustainability (community action) }\end{array}$ \\
\hline CGW4U & $\begin{array}{c}\text { World Issues: A } \\
\text { Geographic } \\
\text { Analysis }\end{array}$ & Gr. 12 & $\begin{array}{l}\text { Planning (land use, zoning) } \\
\text { Sociogeographic (population distribution) } \\
\text { Immigration and Settlement (growth, access to } \\
\text { resources) } \\
\text { Politics (governance) }\end{array}$ \\
\hline CGU4C & $\begin{array}{l}\text { World } \\
\text { Geography: } \\
\text { Urban Patterns } \\
\text { and Interactions }\end{array}$ & Gr.12 & $\begin{array}{l}\text { Planning (land use) } \\
\text { Systems (linear vs. cyclical) } \\
\text { Ecological (pollution, habitat protection) } \\
\text { Politics (government incentives and policy) } \\
\text { Sociogeographic (population distribution) }\end{array}$ \\
\hline CGU4U & $\begin{array}{l}\text { World } \\
\text { Geography: } \\
\text { Human Patterns } \\
\text { and Interactions }\end{array}$ & Gr.12 & $\begin{array}{l}\text { Planning (land use) } \\
\text { Systems (linear vs. cyclical) } \\
\text { Ecological (pollution, habitat protection) } \\
\text { Politics (government incentives and policy) } \\
\text { Sociogeographic (population distribution) }\end{array}$ \\
\hline HFA4M & $\begin{array}{c}\text { Food and } \\
\text { Nutrition Sciences }\end{array}$ & Gr.12 & $\begin{array}{l}\text { Planning (regional food production, urban } \\
\text { agriculture) } \\
\text { Climate (regional food production) } \\
\text { Ecological (regional food production) } \\
\text { Systems (food distribution) }\end{array}$ \\
\hline HSB4M & $\begin{array}{c}\text { Challenge and } \\
\text { Change in Society }\end{array}$ & Gr.12 & $\begin{array}{l}\text { Planning (land use, zoning) } \\
\text { Sociogeographic (population distribution) } \\
\text { Immigration and Settlement (growth, access to } \\
\text { resources) } \\
\text { Politics (governance) }\end{array}$ \\
\hline
\end{tabular}


Table 23: Grade 12 Course Availability and Enrolment

\begin{tabular}{|c|c|c|c|c|c|c|c|}
\hline $\begin{array}{c}\text { Course } \\
\text { Code }\end{array}$ & $\begin{array}{l}\text { Course } \\
\text { Name }\end{array}$ & Grade & $\begin{array}{l}\text { Course } \\
\text { Type }\end{array}$ & $\begin{array}{c}\text { \# of } \\
\text { Schools } \\
\text { Offering } \\
\text { Elective }\end{array}$ & $\begin{array}{c}\% \text { of } \\
\text { Schools } \\
\text { Offering } \\
\text { Elective }\end{array}$ & $\begin{array}{c}\text { \# of } \\
\text { Students } \\
\text { Taking } \\
\text { Course }\end{array}$ & $\begin{array}{c}\text { \% of } \\
\text { Students } \\
\text { Taking } \\
\text { Course* }\end{array}$ \\
\hline CGO4M & $\begin{array}{c}\text { Spatial } \\
\text { Technologies } \\
\text { in Action }\end{array}$ & Gr. 12 & $\begin{array}{l}\text { University/ } \\
\text { College } \\
\text { Preparation } \\
\text { (Grade } 11 \text { \& } \\
12 \text { level) }\end{array}$ & 21 & 2.3 & 409 & 0.2 \\
\hline CGR4E & $\begin{array}{l}\text { Living in a } \\
\text { Sustainable } \\
\text { World }\end{array}$ & Gr. 12 & $\begin{array}{c}\text { Workplace } \\
\text { Preparation } \\
\text { (Grade } 11 \text { \& } \\
12 \text { level) }\end{array}$ & 62 & 6.8 & 398 & 0.2 \\
\hline CGR4M & $\begin{array}{l}\text { Environment } \\
\text { and Resource } \\
\text { Management }\end{array}$ & Gr. 12 & $\begin{array}{l}\text { University/ } \\
\text { College } \\
\text { Preparation } \\
\text { (Grade } 11 \text { \& } \\
12 \text { level) }\end{array}$ & 248 & 27 & 5661 & 2.6 \\
\hline CGW4U & $\begin{array}{c}\text { World Issues: } \\
\text { A Geographic } \\
\text { Analysis }\end{array}$ & Gr. 12 & $\begin{array}{c}\text { University } \\
\text { Preparation } \\
\text { (Grade } 11 \text { \& } \\
12 \text { level) }\end{array}$ & 558 & 61 & 16263 & 7.4 \\
\hline CGU4C & $\begin{array}{l}\text { World } \\
\text { Geography: } \\
\text { Urban } \\
\text { Patterns and } \\
\text { Interactions }\end{array}$ & Gr. 12 & $\begin{array}{c}\text { College } \\
\text { Preparation } \\
\text { (Grade } 11 \text { \& } \\
12 \text { level) }\end{array}$ & 33 & 3.6 & 499 & 0.2 \\
\hline CGU4U & $\begin{array}{l}\text { World } \\
\text { Geography: } \\
\text { Human } \\
\text { Patterns and } \\
\text { Interactions }\end{array}$ & Gr. 12 & $\begin{array}{c}\text { University } \\
\text { Preparation } \\
\text { (Grade } 11 \text { \& } \\
12 \text { level) }\end{array}$ & 44 & 4.8 & 1049 & 0.5 \\
\hline HFA4M & $\begin{array}{l}\text { Food and } \\
\text { Nutrition } \\
\text { Sciences }\end{array}$ & Gr. 12 & $\begin{array}{c}\text { University/ } \\
\text { College } \\
\text { Preparation } \\
\text { (Grade } 11 \text { \& } \\
12 \text { level) }\end{array}$ & 369 & 40 & 16972 & 7.7 \\
\hline HSB4M & $\begin{array}{c}\text { Challenge and } \\
\text { Change in } \\
\text { Society }\end{array}$ & Gr. 12 & $\begin{array}{c}\text { University/ } \\
\text { College } \\
\text { Preparation } \\
\text { (Grade } 11 \text { \& } \\
12 \text { level) }\end{array}$ & 533 & 58 & 24816 & 11 \\
\hline
\end{tabular}

* \% of students in grade

The remaining courses had low availability $(<10 \%)$ and enrolment $(<1 \%)$ and consisted of Living in a Sustainable World (CGR4E), Spatial Technologies, 
(CGO4M), World Geography: Urban Patterns and Interactions (CGU4C), and World Geography: Human Patterns and Interactions (CGU4U). The latter three courses have clear links to urban EE and the themes of Systems and Planning. It would be interesting to note if these courses are better attended in an urban setting. As it stands, the majority of students are not pursuing these courses. Living in a Sustainable World (CGR4E), is the only workplace elective offered in grade 12 therefore it is particularly interesting to note that it experiences low availability and enrolment. It also contains obvious links to place-based education, which is well suited to the learning style of the applied stream. For students pursuing a workplace exit plan, this may pose problems. To ensure continuity and equity in the curriculum, EE should be equally available in all grades and pathways. 


\section{CONCLUSIONS}

The findings of the curriculum review show $11 \%$ of the 675 expectations studied contain some urban EE content. Considering that these courses are not stand-alone EE courses, the frequency with which these themes are present is substantial. Only 3.3\% of the 675 expectations, however, had direct content. Much of the indirect content is found in the optional sections of an expectation (i.e. examples, sample questions). As such, it must overcome the barriers of an overcrowded curriculum, apathy, and lack of resources as well as the feelings of unpreparedness and lack of EE policy awareness felt by educators (Tan \& Pedretti, 2010; EEW, 2015; Chowdhury, 2015). All but one of the urban EE expectations was found in grade 9. No notable difference was found between "academic" and "applied" pathways but themes were generally compartmentalized by subject (i.e. science-ecology vs. geography-planning).

Place-based EE content ( $4.9 \%$ of 675 expectations) is less abundant than urban EE in the curriculum. Like urban EE, it is lacking in grade 10 but also in Science courses. A disproportionate number of expectations are found in the applied, as opposed to the academic, pathway. The number of expectations involving field study (5 of 675 expectations) and action outcomes ( 2 of 675 expectations) is limited.

Analysis of grade 9 and 10 electives highlighted only 4 course options for continuing urban and place-based EE studies. In grade 11 and 12, options are far greater with 9 courses in grade 11 and 8 courses in grade 12. Availability varied from high (i.e. Understanding Canadian Law (CLU3M) offered at $79 \%$ of secondary schools) to very low (i.e. Regional Geography (CGD3M) offered at $0.5 \%$ of schools). Opportunities to continue study existed in every grade and pathway. The average enrolment in all identified elective courses for grades 912 was low $(5.3 \%)$. Future studies may want to explore enrollment data over a greater time span to see how they have changed in the context of policy and curriculum changes.

Combining the results of both the curriculum review and course enrollment, it is clear that the majority of grade 9 and 10 urban and place-based EE is found in 
the mandatory curriculum. Approximately one fifth of the courses highlighted by the Bondar Report for their EE content (Grade 9 and 10 Geography/Science and Grade 10 Civics and Citizenships) contained material related to urban and placebased EE. This holds a lot of promise but upon closer examination, the bulk of relevant expectations are indirectly related to urban EE with few expectations related to place-based EE. Consequently, important EE content is being covered inconsistently or poorly across the province. There are currently very few requirements for field study and/or action outcomes related to place-based or urban $E E$ in the curriculum. This is surprising given that one of three major themes in The Standards for Environmental Education in the Curriculum (2008) is Community (OME, 2008). As discussed at the EEW, partnerships between schools and local businesses, government and community need to be explored. Finding resourceful ways to get outside and exploring opportunities to bring community experiences into the classroom can help overcome funding issues. Schools must become more self-aware and forge lasting connections with their environment both in and out of the classroom. Place-based learning is a wellrecognized concept whose strong presence should be the norm in most learning models. For it to become an establishment, place-based EE needs to be encouraged and supported at all levels.

With respect to pathways, there is a definitive lack of direct urban and placebased EE content at the grade 10 level. The academic pathway shows a slight tendency towards urban EE themes while the applied pathway displays a clear tendency towards place-based EE themes. These trends coincide with the description of course types, which highlight theory in academic courses and "hands-on" approaches in applied courses. Care must be taken to make complex examples of materials and energy systems, characteristic of urban EE, accessible to applied learners, and experiential learning, characteristic of placebased EE, a priority for academic learners.

The compartmentalization of urban and place-based EE topics within secondary school subjects is to be expected to some extent. Alternative approaches to EE include the use of mandatory interdisciplinary projects and 
experiences applied to all secondary students within a carefully considered schedule of learning. The province of Ontario does not employ this type of approach but could consider alternative approaches to EE within its current structure.

Junior students do not have many opportunities to pursue electives and there are few electives available with a strong connection to urban and place-based EE themes. At the senior level (grade 11 and 12), Ontario Secondary School Diploma (OSSD) requirements are less prescriptive and there are more opportunities in every pathway for students to pursue elective studies in urban and place-based EE. Despite this, many of the courses with clear urban and placed-based EE content do not see high enrollment. This either means that student do not see a need to take these courses (e.g. they are not a prerequisite for post-secondary studies), are not interested in their content, experience timetabling conflicts, or do not have these courses offered at their school. Despite the Ministry of Education's focus on promoting EE, inconsistent continuity in senior grades undermines its importance in the minds of students, educators, and the public.

To obtain an OSSD, students must take a combination of mandatory courses and electives. Mandatory courses are the only courses taken by every Ontario secondary school student and as such, they represent a standard curriculum across the province. Currently, the only subjects that students are compelled to take over multiple years are English ( 4 credits) and Mathematics ( 3 credits) (OME, 2014). This is not surprising as literacy and numeracy are important goals of secondary school. In addition to having their own discrete courses, these themes are considered to be overarching ones and the responsibility of all subject teachers. Environmental education does not appear to hold the same clout despite the attention is has been given in recent policy changes. Despite being embedded in the curriculum, the Bondar Report only recommends a "substantial presence in compulsory Grade 9 Geography, Grade 9 and 10 Science, and Grade 10 Civics expectations" (OME, 2007b). Senior grades see even less commitment to EE in the Bondar Report ensuring that secondary 
students "have the opportunity" to take "at least one course" with an EE focus (OME, 2007b). Furthermore, poor enrolment in senior electives fractures urban and place-based EE's progression in the latter part of secondary schooling. With the shift from stand-alone EE courses to an integrated approach, content, distribution, and progression must be carefully designed. Teachers and administrators at EEW agreed that the Bondar Report's vision of EE would be better translated if EE curriculum, programming, initiatives, and community partnerships were more explicit in their wording, better promoted, or mandated consistently. Within policy documents, the goals of urban and place-based EE are often stated in such general terms that it becomes difficult to use them as a guide for curriculum development. Furthermore, curriculum documents are not worded strongly enough to necessitate instruction. There is an identifiable need to improve the intermediate steps between the definition of EE and practice.

With the time constraints placed upon teachers and administrators, the volunteer efforts that sustain most urban and place-based EE initiatives are applied inconsistently. If EE is going to be considered akin to literacy and numeracy, care must be taken to ensure that it is consistently present in the curriculum. Based on the results of the curriculum review, enrollment data, and EEW, urban and place-based EE could have a stronger presence in secondary schools through the use of stronger wording in curriculum documents and the consistent mandating of EE programs. The curriculum review process must ensure focus on both gap finding and quality control to avoid overcrowding and a clear progression of urban and place-based EE topics needs to be present. Similar to the curriculum model, EE initiatives and programs need to be consistently integrated into and prioritized by board/school improvement plans.

To overcome the feelings of teacher unpreparedness in EE (Tan \& Pedretti, 2010; EEW, 2015) and the development of local resources, professional development opportunities must be abundant. Efforts like DEEPER (OISE, 2013) at Faculties of Education are steps in the right direction. Whether in the form of initial teacher training (e.g. pre-service education and additional qualification courses), or less structured professional development, there should 
to be more supports in place for teachers and administrators.

With the agenda for public education being a highly contested domain, the visibility of urban and place-based EE policy and resources needs to be increased and the passion for environmental studies, reignited. For effective implementation of EE, collaboration between subject teachers and communication between diverse stakeholders must be improved upon. It is clear that cultivating an environmentally literate youth who are empowered to shape their future is a process that continues to evolve. 


\section{Appendices}

Appendix A - Main Data Set (OME, 2014)

\begin{tabular}{|c|c|c|c|c|c|c|c|c|c|}
\hline 岁 & 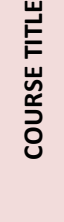 & TYPE & 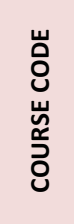 & STRAND & 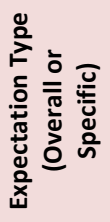 & 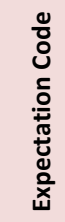 & EXPECTATION & $\begin{array}{l}\text { Urban EE } \\
\text { (Direct } \\
\text { /Indirect } \\
\text { / None) }\end{array}$ & $\begin{array}{c}\text { Place- } \\
\text { Based EE } \\
\text { (Direct / } \\
\text { Indirect / } \\
\text { None) }\end{array}$ \\
\hline 9 & 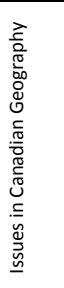 & Academic & CGC1D & $\begin{array}{l}\text { A. Geographic } \\
\text { Inquiry and Skill } \\
\text { Development }\end{array}$ & Specific & $\mathrm{A} 1.1$ & $\begin{array}{l}\text { A1.1 formulate different types of questions } \\
\text { to guide investigations into issues in } \\
\text { Canadian geography (e.g., factual questions: } \\
\text { What factors need to be considered when } \\
\text { analysing the impact of expanding a } \\
\text { highway?; comparative questions: What are } \\
\text { the differences in energy resource } \\
\text { availability between Ontario and Alberta?; } \\
\text { causal questions: How does the } \\
\text { infrastructure of this community support } \\
\text { environmental sustainability?) }\end{array}$ & $\mathrm{N}$ & $\mathrm{N}$ \\
\hline 9 & 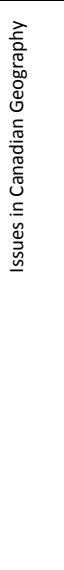 & Academic & CGC1D & $\begin{array}{l}\text { A. Geographic } \\
\text { Inquiry and Skill } \\
\text { Development }\end{array}$ & Specific & $\mathrm{A} 1.5$ & $\begin{array}{l}\text { A1.5 use the concepts of geographic thinking } \\
\text { (i.e., spatial significance, patterns and } \\
\text { trends, interrelationships, geographic } \\
\text { perspective) when analysing and evaluating } \\
\text { data and information, formulating } \\
\text { conclusions, and making judgements about } \\
\text { geographic issues relating to Canada (e.g., } \\
\text { use the concept of spatial significance to } \\
\text { evaluate competing land-use options, such } \\
\text { as fruit farming and urban development; } \\
\text { apply the concept of patterns and trends to } \\
\text { temperature and precipitation data to assess } \\
\text { how the climate of a region has changed } \\
\text { over time; use the concept of } \\
\text { interrelationships to assess how changes in } \\
\text { technology affect industry, employment, } \\
\text { and the consumption of natural resources; } \\
\text { use the concept of geographic perspective } \\
\text { to analyse the environ- mental, social, } \\
\text { political, and economic impacts of } \\
\text { globalization on various First Nations, Métis, } \\
\text { and Inuit communities) }\end{array}$ & $\mathrm{N}$ & $\mathrm{N}$ \\
\hline 9 & 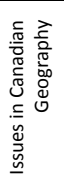 & Academic & CGC1D & $\begin{array}{l}\text { A. Geographic } \\
\text { Inquiry and Skill } \\
\text { Development }\end{array}$ & Specific & A1.6 & $\begin{array}{l}\text { A1.6 evaluate and synthesize their findings } \\
\text { to formulate conclusions and/or make } \\
\text { judgements or predictions about the issues } \\
\text { they are investigating }\end{array}$ & $\mathrm{N}$ & $\mathrm{N}$ \\
\hline 9 & 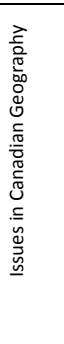 & Academic & CGC1D & $\begin{array}{l}\text { A. Geographic } \\
\text { Inquiry and Skill } \\
\text { Development }\end{array}$ & Specific & $\mathrm{A} 2.3$ & $\begin{array}{l}\text { A2.3 apply the concepts of geographic } \\
\text { thinking when analysing current events } \\
\text { involving geographic issues (e.g., to identify } \\
\text { locational factors that affect the importance } \\
\text { of an issue; to identify patterns and trends } \\
\text { that provide context for an issue; to identify } \\
\text { interrelationships that clarify the factors } \\
\text { involved in an issue; to understand the } \\
\text { implications of different aspects of an issue } \\
\text { and/or different points of view about the } \\
\text { issue) in order to enhance their } \\
\text { understanding of these issues and their role } \\
\text { as informed citizens }\end{array}$ & $\mathrm{N}$ & $\mathrm{N}$ \\
\hline
\end{tabular}




\begin{tabular}{|c|c|c|c|c|c|c|c|c|c|}
\hline 9 & 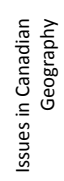 & Academic & CGC1D & $\begin{array}{l}\text { B. Interactions } \\
\text { in the Physical } \\
\text { Environment }\end{array}$ & Specific & B1.2 & $\begin{array}{l}\text { B1.2 analyse interrelationships between } \\
\text { Canada's physical characteristics and various } \\
\text { human activities that they support (e.g., } \\
\text { mountainous landforms support recreation; } \\
\text { water bodies and flat land facilitate urban } \\
\text { development and transportation) }\end{array}$ & D & $\mathrm{N}$ \\
\hline 9 & 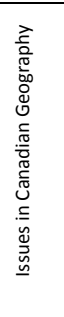 & Academic & CGC1D & $\begin{array}{l}\text { B. Interactions } \\
\text { in the Physical } \\
\text { Environment }\end{array}$ & Specific & B1.3 & $\begin{array}{l}\text { B1.3 assess environmental, economic, social, } \\
\text { and/or political consequences for Canada of } \\
\text { changes in some of the Earth's physical } \\
\text { processes (e.g., warming in the North is } \\
\text { leading to a shorter, less reliable ice season } \\
\text { and changes in plant and animal populations } \\
\text { [environmental], threatening traditional } \\
\text { Inuit culture [social], expanding } \\
\text { opportunities for resource exploitation } \\
\text { [economic], and creating conflict between } \\
\text { nation states over territorial claims } \\
\text { [political]) }\end{array}$ & $\mathrm{N}$ & $\mathrm{N}$ \\
\hline 9 & 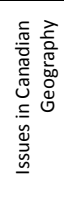 & Academic & CGC1D & $\begin{array}{l}\text { B. Interactions } \\
\text { in the Physical } \\
\text { Environment }\end{array}$ & Specific & B1.4 & $\begin{array}{l}\text { B1.4 explain how human activities can alter } \\
\text { physical processes and contribute to } \\
\text { occurrences of natural events and } \\
\text { phenomena (e.g., paving over land can alter } \\
\text { drainage patterns and cause sink holes; } \\
\text { some agricultural practices can contribute to } \\
\text { soil erosion; deforestation can make slopes } \\
\text { vulnerable to landslides) }\end{array}$ & 1 & $\mathrm{~N}$ \\
\hline 9 & 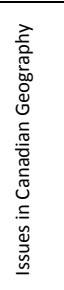 & Academic & CGC1D & $\begin{array}{l}\text { B. Interactions } \\
\text { in the Physical } \\
\text { Environment }\end{array}$ & Specific & B3.2 & $\begin{array}{l}\text { B3.2 explain how geological, hydrological, } \\
\text { and climatic processes formed and continue } \\
\text { to shape Canada's landscape (e.g., folding } \\
\text { and faulting formed and continue to shape } \\
\text { Canada's western mountains; glacial } \\
\text { recession left scoured landscape in Ontario's } \\
\text { north and fertile landscape in the south and } \\
\text { shaped the Great Lakes drainage system; } \\
\text { winds continue to change landform features } \\
\text { in the badlands of Alberta) }\end{array}$ & $\mathrm{N}$ & $\mathrm{N}$ \\
\hline 9 & 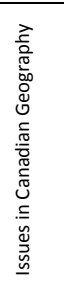 & Academic & CGC1D & $\begin{array}{l}\text { C. Managing } \\
\text { Canada's } \\
\text { Resources and } \\
\text { Industries }\end{array}$ & Specific & $\mathrm{C} 1.1$ & $\begin{array}{l}\text { C1.1 describe strategies that industries and } \\
\text { governments have implemented to increase } \\
\text { the sustainability of Canada's natural } \\
\text { resources (e.g., green belts, tourism } \\
\text { restrictions in environment- ally fragile } \\
\text { regions, wildlife culling, rehabilitation of } \\
\text { aggregate quarries, sustainable yield } \\
\text { management of forests and fisheries, } \\
\text { recovery of minerals from mine tailings, } \\
\text { community composting, recycling and } \\
\text { recovery), and evaluate their effectiveness }\end{array}$ & $\mathrm{N}$ & $\mathrm{N}$ \\
\hline 9 & 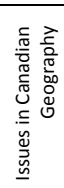 & Academic & CGC1D & $\begin{array}{l}\text { C. Managing } \\
\text { Canada's } \\
\text { Resources and } \\
\text { Industries }\end{array}$ & Specific & $\mathrm{C} 2.4$ & $\begin{array}{l}\text { C2.4 assess the feasibility of using selected } \\
\text { renewable and alternative energy sources } \\
\text { (e.g., solar, wind, tidal, hydro) to augment or } \\
\text { replace existing power sources in various } \\
\text { parts of Canada }\end{array}$ & $\mathrm{N}$ & $\mathrm{N}$ \\
\hline 9 & 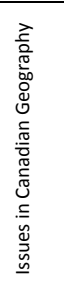 & Academic & CGC1D & $\begin{array}{l}\text { C. Managing } \\
\text { Canada's } \\
\text { Resources and } \\
\text { Industries }\end{array}$ & Specific & C3.4 & $\begin{array}{l}\text { C3.4 analyse the main factors (e.g., } \\
\text { availability of resources, distance to market, } \\
\text { transportation costs, government incentives, } \\
\text { labour force) that need to be considered } \\
\text { when determining the location of sites for } \\
\text { different types of industries (e.g., resource } \\
\text { extraction industries, manufacturing } \\
\text { industries, service industries, knowledge- } \\
\text { based industries, cultural industries) }\end{array}$ & $\mathrm{D}$ & $\mathrm{N}$ \\
\hline
\end{tabular}




\begin{tabular}{|c|c|c|c|c|c|c|c|c|c|}
\hline 9 & 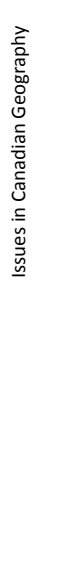 & Academic & CGC1D & $\begin{array}{l}\text { D. Changing } \\
\text { Populations }\end{array}$ & Specific & D1.1 & $\begin{array}{l}\text { D1.1 analyse the impact of selected } \\
\text { population trends on people living in } \\
\text { Canadian communities (e.g., aging } \\
\text { population increases demand for health care } \\
\text { and institutional support; increasing } \\
\text { population density affects housing, job, and } \\
\text { transportation needs; increased number of } \\
\text { working parents with responsibilities for } \\
\text { both child and elder care affects family life } \\
\text { and housing needs; neighbourhoods that } \\
\text { consist largely of a single ethnic or cultural } \\
\text { group pose challenges to social integration; } \\
\text { growth of First Nations, Métis, and Inuit } \\
\text { populations increases need for education, } \\
\text { housing, health care, infrastructure, and } \\
\text { resolution of land claims and rights disputes) } \\
\text { and their implications for the future (e.g., } \\
\text { aging population will further increase } \\
\text { demand for health care, retirement housing, } \\
\text { and transit support; increased diversity of } \\
\text { newcomers will increase demand for } \\
\text { language training) }\end{array}$ & 1 & $\mathrm{~N}$ \\
\hline 9 & 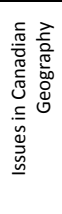 & Academic & CGC1D & $\begin{array}{l}\text { D. Changing } \\
\text { Populations }\end{array}$ & Specific & \begin{tabular}{|l|l|} 
D2.1 \\
\end{tabular} & $\begin{array}{l}\text { D2.1 identify factors that influence where } \\
\text { immigrants settle in Canada, and assess the } \\
\text { opportunities and challenges presented by } \\
\text { immigration and cultural diversity in Canada } \\
\text { (e.g., expansion of business opportunities, } \\
\text { cultural enrichment, global engagement and } \\
\text { citizenship; neighbourhood segregation and } \\
\text { lack of social integration, hate crimes) }\end{array}$ & 1 & $\mathrm{~N}$ \\
\hline 9 & 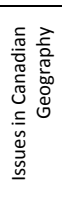 & Academic & CGC1D & $\begin{array}{l}\text { D. Changing } \\
\text { Populations }\end{array}$ & Specific & D2.2 & $\begin{array}{l}\text { D2.2 evaluate strategies used to address the } \\
\text { needs of various immigrant groups within } \\
\text { communities (e.g., provision of language } \\
\text { training, celebration of traditions from } \\
\text { various cultures, provision of cultural and } \\
\text { social support services in several languages, } \\
\text { addressing hate crimes through community } \\
\text { policing and education) }\end{array}$ & 1 & $\mathrm{~N}$ \\
\hline 9 & 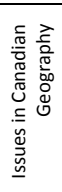 & Academic & CGC1D & $\begin{array}{l}\text { D. Changing } \\
\text { Populations }\end{array}$ & Specific & $\begin{array}{l}\text { D2.3 } \\
\end{array}$ & $\begin{array}{l}\text { D2.3 analyse social, political, and economic } \\
\text { impacts of Canada's immigration and } \\
\text { refugee policies }\end{array}$ & 1 & $\mathrm{~N}$ \\
\hline 9 & 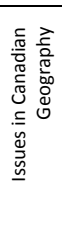 & Academic & CGC1D & $\begin{array}{l}\text { D. Changing } \\
\text { Populations }\end{array}$ & Specific & D3.2 & $\begin{array}{l}\text { D3.2 identify factors (e.g., job opportunities, } \\
\text { accessibility of transportation and } \\
\text { communication networks, availability of } \\
\text { social services, availability of natural } \\
\text { resources, cultural attitudes) that influence } \\
\text { the demographic characteristics of } \\
\text { settlements across Canada (e.g., ethnic } \\
\text { composition, age-sex distribution, types of } \\
\text { employment, levels of education) }\end{array}$ & 1 & $\mathrm{~N}$ \\
\hline 9 & 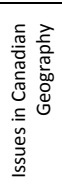 & Academic & CGC1D & $\begin{array}{l}\text { D. Changing } \\
\text { Populations }\end{array}$ & Specific & D3.3 & $\begin{array}{l}\text { D3.3 analyse the major demographic } \\
\text { characteristics of the Canadian population } \\
\text { (e.g., rate of natural increase, growth rate, } \\
\text { age-sex distribution, dependency load, } \\
\text { doubling time, cultural background) }\end{array}$ & 1 & $\mathrm{~N}$ \\
\hline 9 & 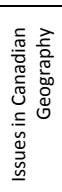 & Academic & CGC1D & $\begin{array}{l}\text { D. Changing } \\
\text { Populations }\end{array}$ & Specific & D3.4 & $\begin{array}{l}\text { D3.4 compare settlement and population } \\
\text { characteristics of selected communities in } \\
\text { Canada with those in other parts of the } \\
\text { country and the world }\end{array}$ & 1 & $\mathrm{~N}$ \\
\hline
\end{tabular}




\begin{tabular}{|c|c|c|c|c|c|c|c|c|c|}
\hline 9 & 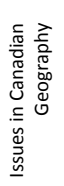 & Academic & CGC1D & $\begin{array}{l}\text { D. Changing } \\
\text { Populations }\end{array}$ & Specific & D3.5 & $\begin{array}{l}\text { D3.5 analyse trends in the migration of } \\
\text { people within Canada (e.g., increase in First } \\
\text { Nations, Métis, and Inuit peoples moving } \\
\text { into urban centres, rural residents moving to } \\
\text { urban centres, people from central and } \\
\text { eastern provinces moving to northern } \\
\text { Alberta and the Northwest Territories) }\end{array}$ & 1 & $\mathrm{~N}$ \\
\hline 9 & 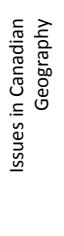 & Academic & CGC1D & $\begin{array}{l}\text { D. Changing } \\
\text { Populations }\end{array}$ & Specific & D3.1 & $\begin{array}{l}\text { D3.1 describe patterns of population } \\
\text { settlement in Canada (e.g., linear, scattered, } \\
\text { clustered), and assess the importance of } \\
\text { various factors in determining population } \\
\text { size, distribution, and density (e.g., } \\
\text { landforms; climate; proximity to food and } \\
\text { water sources; connections to } \\
\text { transportation, communications, energy, } \\
\text { and economic networks) }\end{array}$ & $\mathrm{D}$ & $\mathrm{N}$ \\
\hline 9 & 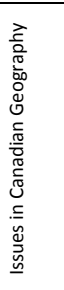 & Academic & CGC1D & $\begin{array}{l}\text { E. Livable } \\
\text { Communities }\end{array}$ & Specific & E2.2 & $\begin{array}{l}\text { E2.2 analyse various economic, social, and } \\
\text { political impacts of urban growth (e.g., cost } \\
\text { of expanding infrastructure and public } \\
\text { services; health impacts, such as faster } \\
\text { spread of disease in densely populated } \\
\text { communities, increases in asthma attacks as } \\
\text { a result of poor air quality, and stress related } \\
\text { to crowding; traffic congestion and related } \\
\text { economic costs; conflict over development } \\
\text { priorities) }\end{array}$ & $\mathrm{D}$ & $\mathrm{N}$ \\
\hline 9 & 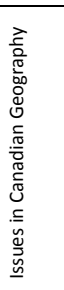 & Academic & CGC1D & $\begin{array}{l}\text { E. Livable } \\
\text { Communities }\end{array}$ & Specific & E1.2 & $\begin{array}{l}\text { E1.2 analyse the sustainability of existing } \\
\text { and proposed transportation systems, } \\
\text { locally, provincially, nationally, and } \\
\text { internationally, and assess options for their } \\
\text { future development (e.g., widening } \\
\text { highways, creating high occupancy vehicle } \\
\text { lanes, creating bike lanes, improving mass } \\
\text { transit infrastructure, upgrading train } \\
\text { corridors, opening the Northwest Passage to } \\
\text { international shipping) }\end{array}$ & $\mathrm{D}$ & $\mathrm{N}$ \\
\hline 9 & 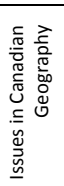 & Academic & CGC1D & $\begin{array}{l}\text { E. Livable } \\
\text { Communities }\end{array}$ & Specific & E2.1 & $\begin{array}{l}\text { E2.1 assess the impact of urban growth on } \\
\text { natural systems (e.g., impact of urban } \\
\text { sprawl, vehicle use, and waste disposal on } \\
\text { water and air quality) }\end{array}$ & $\mathrm{D}$ & $\mathrm{N}$ \\
\hline 9 & 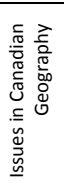 & Academic & CGC1D & $\begin{array}{l}\text { E. Livable } \\
\text { Communities }\end{array}$ & Overall & E2 & $\begin{array}{l}\text { E2. Impacts of Urban Growth : analyse } \\
\text { impacts of urban growth in Canada (FOCUS } \\
\text { ON : Spatial Significance; Geographic } \\
\text { Perspective) }\end{array}$ & $\mathrm{D}$ & $\mathrm{N}$ \\
\hline 9 & 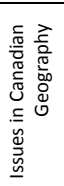 & Academic & CGC1D & $\begin{array}{l}\text { E. Livable } \\
\text { Communities }\end{array}$ & Specific & E3.1 & $\begin{array}{l}\text { E3.1 analyse the characteristics of different } \\
\text { land uses in a community (e.g., size and } \\
\text { distribution of transportation corridors, } \\
\text { differences in residential types, location of } \\
\text { industrial land), and explain how these } \\
\text { characteristics and their spatial distribution } \\
\text { affect the community }\end{array}$ & $\mathrm{D}$ & I \\
\hline 9 & 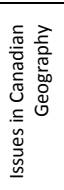 & Academic & CGC1D & $\begin{array}{l}\text { E. Livable } \\
\text { Communities }\end{array}$ & Specific & E1.1 & $\begin{array}{l}\text { E1.1 analyse the effects of food production } \\
\text { practices, distribution methods, and } \\
\text { consumer choices on the sustainability of } \\
\text { Canada's food system }\end{array}$ & $\mathrm{D}$ & $\mathrm{N}$ \\
\hline
\end{tabular}




\begin{tabular}{|c|c|c|c|c|c|c|c|c|c|}
\hline 9 & 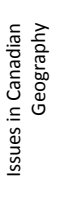 & Academic & CGC1D & $\begin{array}{l}\text { E. Livable } \\
\text { Communities }\end{array}$ & Specific & E1.4 & $\begin{array}{l}\text { E1.4 analyse factors that affect the social } \\
\text { and economic sustainability of communities } \\
\text { (e.g., diversified economy; investment in } \\
\text { public services and infrastructure, such as } \\
\text { transportation networks, health and social } \\
\text { services, recreational and cultural facilities; } \\
\text { educational opportunities; recognition of } \\
\text { heritage; diverse neighbourhoods) }\end{array}$ & $\mathrm{N}$ & 1 \\
\hline 9 & 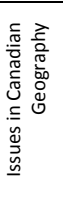 & Academic & CGC1D & $\begin{array}{l}\text { E. Livable } \\
\text { Communities }\end{array}$ & $\begin{array}{l}\text { Specific } \\
\end{array}$ & E1.5 & $\begin{array}{l}\text { E1.5 propose courses of action that would } \\
\text { make a community more sustainable (e.g., } \\
\text { improving community/neighbourhood } \\
\text { amenities, establishing local markets, } \\
\text { replacing individual ownership of equipment } \\
\text { with cooperative ownership, sharing cars, } \\
\text { introducing a rental bike network, expanding } \\
\text { the amount of green space) }\end{array}$ & $\mathrm{N}$ & 1 \\
\hline 9 & 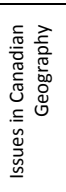 & Academic & CGC1D & $\begin{array}{l}\text { E. Livable } \\
\text { Communities }\end{array}$ & Specific & E2.3 & $\begin{array}{l}\text { E2.3 describe strategies that urban planners } \\
\text { use to control urban sprawl (e.g., green } \\
\text { belts, high density residential infill, } \\
\text { gentrification), and analyse examples of } \\
\text { their implementation }\end{array}$ & D & $N$ \\
\hline 9 & 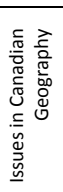 & Academic & CGC1D & $\begin{array}{l}\text { E. Livable } \\
\text { Communities }\end{array}$ & Specific & E3.2 & $\begin{array}{l}\text { E3.2 explain how the natural environment } \\
\text { may influence land-use patterns within the } \\
\text { built environment (e.g., roads tend to be on } \\
\text { flatter land; parks are often near water) }\end{array}$ & $\mathrm{D}$ & $\mathrm{N}$ \\
\hline 9 & 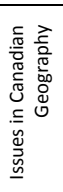 & Academic & CGC1D & $\begin{array}{l}\text { E. Livable } \\
\text { Communities }\end{array}$ & Specific & E3.3 & $\begin{array}{l}\text { E3.3 analyse a land-use map or official plan } \\
\text { for } \\
\text { a specific community, and describe the } \\
\text { spatial significance of the community's land- } \\
\text { use pattern }\end{array}$ & D & 1 \\
\hline 9 & 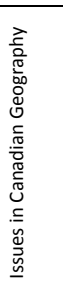 & Applied & CGC1P & $\begin{array}{l}\text { A. Geographic } \\
\text { Inquiry and Skill } \\
\text { Development }\end{array}$ & Specific & $\overline{\mathrm{A} 1.1}$ & $\begin{array}{l}\text { A1.1 formulate different types of questions } \\
\text { to guide investigations into issues in } \\
\text { Canadian geography (e.g., factual questions: } \\
\text { What are the cultural backgrounds of people } \\
\text { living in your community?; comparative } \\
\text { questions: Which uses of energy have the } \\
\text { highest consumption?; causal } \\
\text { questions: “'How can increasing the use of } \\
\text { public transit contribute to better air quality } \\
\text { in your community?) }\end{array}$ & $\mathrm{N}$ & $\mathrm{N}$ \\
\hline 9 & 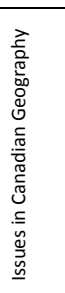 & Applied & CGC1P & $\begin{array}{l}\text { A. Geographic } \\
\text { Inquiry and Skill } \\
\text { Development }\end{array}$ & Specific & A1.2 & $\begin{array}{l}\text { A1.2 select and organize relevant data and } \\
\text { information on geographic issues from a } \\
\text { variety of primary and secondary sources } \\
\text { (e.g., primary: raw data from field work, } \\
\text { both quantitative and qualitative; statistics; } \\
\text { photographs; satellite images; secondary: } \\
\text { newspaper columns, books, atlases, } \\
\text { geographic magazines, websites, graphs, } \\
\text { charts, published maps), ensuring that their } \\
\text { sources represent a diverse range of views }\end{array}$ & $\mathrm{N}$ & $\mathrm{N}$ \\
\hline 9 & 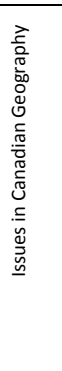 & Applied & CGC1P & $\begin{array}{l}\text { A. Geographic } \\
\text { Inquiry and Skill } \\
\text { Development }\end{array}$ & Specific & A1.4 & $\begin{array}{l}\text { A1.4 interpret and analyse data and } \\
\text { information relevant to their investigations, } \\
\text { using various tools, strategies, and } \\
\text { approaches appropriate for geographic } \\
\text { inquiry (e.g., use data about their way of } \\
\text { living and use of resources to calculate their } \\
\text { ecological footprint and compare it to the } \\
\text { ecological footprints of people in Canada } \\
\text { and other parts of the world; use graphic } \\
\text { organizers, such as cross-classification tables } \\
\text { or ranking ladders, to interpret the potential } \\
\text { economic, political, social, and/or } \\
\text { environmental impacts of an industry that } \\
\text { wants to establish itself in their community) }\end{array}$ & $N$ & $\mathrm{~N}$ \\
\hline
\end{tabular}




\begin{tabular}{|c|c|c|c|c|c|c|c|c|c|}
\hline 9 & 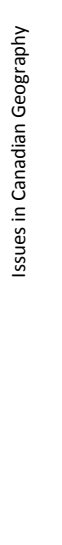 & Applied & CGC1P & $\begin{array}{l}\text { A. Geographic } \\
\text { Inquiry and Skill } \\
\text { Development }\end{array}$ & Specific & A.15 & $\begin{array}{l}\text { A1.5 use the concepts of geographic thinking } \\
\text { (i.e., spatial significance, patterns and } \\
\text { trends, interrelationships, geographic } \\
\text { perspective) when analysing and evaluating } \\
\text { data and information, formulating } \\
\text { conclusions, and making judgements about } \\
\text { geographic issues relating to Canada (e.g., } \\
\text { use the concept of spatial significance to } \\
\text { assess the characteristics of locations for } \\
\text { different types of land use when planning } \\
\text { city spaces; use the concept of patterns and } \\
\text { trends to analyse the impact of earthquakes } \\
\text { on urban structures; use the concept of } \\
\text { interrelationships to guide personal } \\
\text { behaviours that may affect the natural } \\
\text { environment; use the concept of geographic } \\
\text { perspective to analyse the environmental, } \\
\text { social, political, and/or economic impacts of } \\
\text { building a highway or energy pipeline } \\
\text { through the lands of a First Nation, Métis, } \\
\text { and/or Inuit community) }\end{array}$ & $\mathrm{N}$ & $\mathrm{N}$ \\
\hline 9 & 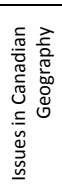 & Applied & CGC1P & $\begin{array}{l}\text { A. Geographic } \\
\text { Inquiry and Skill } \\
\text { Development }\end{array}$ & Specific & A1.6 & $\begin{array}{l}\text { A1.6 evaluate and synthesize their findings } \\
\text { to formulate conclusions and/or make } \\
\text { judgements or predictions about the issues } \\
\text { they are investigating }\end{array}$ & $\mathrm{N}$ & $\mathrm{N}$ \\
\hline 9 & 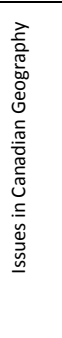 & Applied & CGC1P & $\begin{array}{l}\text { A. Geographic } \\
\text { Inquiry and Skill } \\
\text { Development }\end{array}$ & Specific & A2.3 & $\begin{array}{l}\text { A2.3 apply the concepts of geographic } \\
\text { thinking when analysing current events } \\
\text { involving geographic issues (e.g., to identify } \\
\text { locational factors that affect the importance } \\
\text { of an issue; to identify patterns and trends } \\
\text { that provide context for an issue; to identify } \\
\text { interrelationships that clarify factors } \\
\text { involved in an issue; to understand the } \\
\text { implications of different aspects of an issue } \\
\text { and/or different points of view about the } \\
\text { issue) in order to enhance their } \\
\text { understanding of these issues and their role } \\
\text { as informed citizens }\end{array}$ & $N$ & $\mathrm{~N}$ \\
\hline 9 & 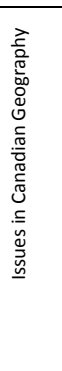 & Applied & CGC1P & $\begin{array}{l}\text { B. Interactions } \\
\text { in the Physical } \\
\text { Environment }\end{array}$ & Specific & B1.4 & $\begin{array}{l}\text { B1.4 explain how human activities in their } \\
\text { local region can have an impact on natural } \\
\text { processes (e.g., vehicle use, chimney } \\
\text { emissions, and barbecue and lawn mower } \\
\text { usage contribute to smog and can change } \\
\text { the acidity of lake water; blasting and drilling } \\
\text { may trigger land instability; removing trees } \\
\text { and paving over land change the amount of } \\
\text { water going into the soil and back into the } \\
\text { air; expansion of highways can lead to more } \\
\text { animals being struck by vehicles and can also } \\
\text { disrupt animal migration patterns and } \\
\text { separate animals from their food supplies, } \\
\text { thus endangering their populations) }\end{array}$ & 1 & 1 \\
\hline 9 & 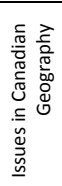 & Applied & CGC1P & $\begin{array}{l}\text { B. Interactions } \\
\text { in the Physical } \\
\text { Environment }\end{array}$ & Specific & B2.2 & $\begin{array}{l}\text { B2.2 explain the influence of Canada's } \\
\text { natural characteristics (e.g., climate, soils, } \\
\text { topography, proximity to water, natural } \\
\text { resources) on the spatial distribution of its } \\
\text { population }\end{array}$ & $\mathrm{D}$ & $\mathrm{N}$ \\
\hline 9 & 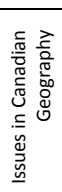 & Applied & CGC1P & $\begin{array}{l}\text { B. Interactions } \\
\text { in the Physical } \\
\text { Environment }\end{array}$ & Specific & B3.1 & $\begin{array}{l}\text { B3.1 describe the natural characteristics } \\
\text { (e.g., landscape, weather, drainage, } \\
\text { vegetation, wildlife) of their local area or } \\
\text { region, and explain their significance for the } \\
\text { region }\end{array}$ & $\mathrm{N}$ & D \\
\hline 9 & 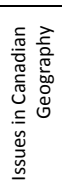 & Applied & CGC1P & $\begin{array}{l}\text { B. Interactions } \\
\text { in the Physical } \\
\text { Environment }\end{array}$ & Specific & B3.2 & $\begin{array}{l}\text { B3.2 compare the natural characteristics of } \\
\text { their local community with the natural } \\
\text { characteristics of other communities across } \\
\text { Canada }\end{array}$ & $\mathrm{N}$ & $\mathrm{D}$ \\
\hline
\end{tabular}




\begin{tabular}{|c|c|c|c|c|c|c|c|c|c|}
\hline 9 & 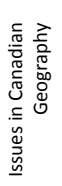 & Applied & CGC1P & $\begin{array}{l}\text { C. Managing } \\
\text { Canada's } \\
\text { Resources and } \\
\text { Industries }\end{array}$ & Specific & C1.1 & $\begin{array}{l}\text { C1.1 identify major sources of energy used } \\
\text { in Canada (e.g., fossil fuels, nuclear, hydro), } \\
\text { and assess the viability of alternative energy } \\
\text { options for various communities across } \\
\text { Canada }\end{array}$ & D & $\mathrm{N}$ \\
\hline 9 & 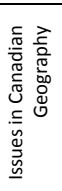 & Applied & CGC1P & $\begin{array}{l}\text { C. Managing } \\
\text { Canada's } \\
\text { Resources and } \\
\text { Industries }\end{array}$ & Specific & C2.3 & $\begin{array}{l}\text { C2.3 assess the economic, environmental, } \\
\text { social, and political significance of a specific } \\
\text { industry for their local area or another area } \\
\text { of their choice }\end{array}$ & $\mathrm{N}$ & 1 \\
\hline 9 & 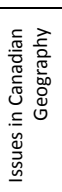 & Applied & CGC1P & $\begin{array}{l}\text { D. Changing } \\
\text { Populations }\end{array}$ & Specific & D1.1 & $\begin{array}{l}\text { D1.1 assess economic, social, and } \\
\text { environmental impacts of major population } \\
\text { trends in Canada today (e.g., aging of the } \\
\text { population; increasing cultural, linguistic, } \\
\text { and social diversity; changes in family } \\
\text { structure) }\end{array}$ & 1 & $\mathrm{~N}$ \\
\hline 9 & 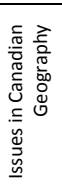 & Applied & CGC1P & $\begin{array}{l}\text { D. Changing } \\
\text { Populations }\end{array}$ & Specific & D1.2 & $\begin{array}{l}\text { D1.2 describe some opportunities (e.g., } \\
\text { cultural enrichment, new economic } \\
\text { opportunities) and challenges (e.g., } \\
\text { communication barriers, ghettoization) that } \\
\text { may arise for communities whose } \\
\text { populations come from a diversity of cultural } \\
\text { backgrounds }\end{array}$ & $T$ & $N$ \\
\hline 9 & 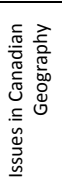 & Applied & CGC1P & $\begin{array}{l}\text { D. Changing } \\
\text { Populations }\end{array}$ & Specific & $\begin{array}{ll}\text { D1.3 } \\
\end{array}$ & $\begin{array}{l}\text { D1.3 describe ways in which Canadian } \\
\text { society can respond to the needs of a } \\
\text { changing population }\end{array}$ & $T$ & $N$ \\
\hline 9 & 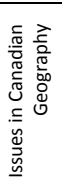 & Applied & CGC1P & $\begin{array}{l}\text { D. Changing } \\
\text { Populations }\end{array}$ & Specific & D1.4 & $\begin{array}{l}\text { D1.4 analyse population trends in their local } \\
\text { community or area, assess related needs, } \\
\text { and recommend appropriate responses to } \\
\text { those needs }\end{array}$ & 1 & 1 \\
\hline 9 & 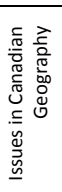 & Applied & CGC1P & $\begin{array}{l}\text { D. Changing } \\
\text { Populations }\end{array}$ & Specific & D2.1 & $\begin{array}{l}\text { D2.1 analyse current immigration trends in } \\
\text { Canada (e.g., trends in overall numbers, } \\
\text { numbers in different immigrant categories, } \\
\text { countries of origin) }\end{array}$ & 1 & $\mathrm{~N}$ \\
\hline 9 & 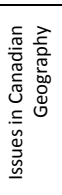 & Applied & CGC1P & $\begin{array}{l}\text { D. Changing } \\
\text { Populations }\end{array}$ & Specific & D3.1 & $\begin{array}{l}\text { D3.1 describe key characteristics of different } \\
\text { types of population settlements in Canada } \\
\text { (e.g., towns, cities, census metropolitan } \\
\text { areas, megalopolises, First Nations reserves), } \\
\text { and explain their distribution (e.g., near } \\
\text { rivers, highways, natural resources) }\end{array}$ & $\mathrm{D}$ & $\mathrm{N}$ \\
\hline 9 & 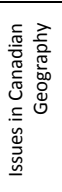 & Applied & CGC1P & $\begin{array}{l}\text { D. Changing } \\
\text { Populations }\end{array}$ & Specific & D3.2 & $\begin{array}{l}\text { D3.2 describe the major demographic } \\
\text { characteristics of present-day Canada (e.g., } \\
\text { population density, growth rate, age-sex } \\
\text { distribution, cultural diversity), and compare } \\
\text { them to those of your community or local } \\
\text { area }\end{array}$ & 1 & 1 \\
\hline 9 & 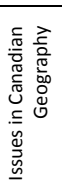 & Applied & CGC1P & $\begin{array}{l}\text { E. Livable } \\
\text { Communities }\end{array}$ & Specific & E1.2 & $\begin{array}{l}\text { E1.2 identify various ways in which } \\
\text { communities in Canada dispose of their } \\
\text { waste material (e.g., landfilling, composting, } \\
\text { incineration, primary and secondary sewage } \\
\text { treatment), and describe potential } \\
\text { environmental impacts of these methods }\end{array}$ & $\mathrm{D}$ & $\mathrm{N}$ \\
\hline 9 & 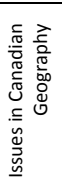 & Applied & CGC1P & $\begin{array}{l}\text { E. Livable } \\
\text { Communities }\end{array}$ & Specific & E1.4 & $\begin{array}{l}\text { E1.4 identify actions that individuals can } \\
\text { take to live more sustainably, and explain } \\
\text { the benefits for their local community }\end{array}$ & $\mathrm{N}$ & $D$ \\
\hline
\end{tabular}




\begin{tabular}{|c|c|c|c|c|c|c|c|c|c|}
\hline 9 & 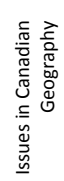 & Applied & CGC1P & $\begin{array}{l}\text { E. Livable } \\
\text { Communities }\end{array}$ & Specific & E2.2 & $\begin{array}{l}\text { E2.2 assess the compatibility of different } \\
\text { types of land uses with each other within } \\
\text { their local community (e.g., land uses that } \\
\text { conflict with each other, land uses that make } \\
\text { other land uses more efficient or less } \\
\text { efficient) }\end{array}$ & $\mathrm{D}$ & D \\
\hline 9 & 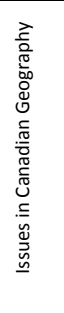 & Applied & CGC1P & $\begin{array}{l}\text { E. Livable } \\
\text { Communities }\end{array}$ & Specific & E2.3 & $\begin{array}{l}\text { E2.3 explain how changes in land use can } \\
\text { affect the growth or decline of different } \\
\text { parts of a community (e.g., new suburban } \\
\text { malls can drain business from downtown } \\
\text { stores and lead to the decline of a } \\
\text { community's central core; replacing an old } \\
\text { industrial district with retail or recreational } \\
\text { development, adding additional } \\
\text { transportation } \\
\text { capacity, new cultural institutions, } \\
\text { amenities, industrial parks can stimulate } \\
\text { growth) }\end{array}$ & $\mathrm{D}$ & 1 \\
\hline 9 & 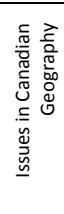 & Applied & CGC1P & $\begin{array}{l}\text { E. Livable } \\
\text { Communities }\end{array}$ & Specific & E2.4 & $\begin{array}{l}\text { E2.4 analyse the impact of a selected project } \\
\text { on a community (e.g., residential or resort } \\
\text { development, urban renewal, installation of } \\
\text { water and waste management systems, } \\
\text { creation of a park or recreational site, } \\
\text { addition of bike lanes on major streets, } \\
\text { opening of a mine near a reserve } \\
\text { community) }\end{array}$ & $\mathrm{N}$ & 1 \\
\hline 9 & 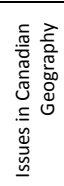 & Applied & CGC1P & $\begin{array}{l}\text { E. Livable } \\
\text { Communities }\end{array}$ & Overall & E3 & $\begin{array}{l}\text { E3. Patterns of Land Use: describe patterns } \\
\text { of land use in their local community (FOCUS } \\
\text { ON: Spatial Significance; Patterns and } \\
\text { Trends) }\end{array}$ & $\mathrm{D}$ & $\mathrm{D}$ \\
\hline 9 & 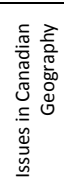 & Applied & CGC1P & $\begin{array}{l}\text { E. Livable } \\
\text { Communities }\end{array}$ & Specific & E3.1 & $\begin{array}{l}\text { E3.1 describe different types of land use } \\
\text { within their community (e.g., commercial, } \\
\text { transportation, industrial, residential, } \\
\text { institutional, recreational, agricultural, open } \\
\text { space), and explain reasons for their location }\end{array}$ & $\mathrm{D}$ & $\mathrm{D}$ \\
\hline 9 & 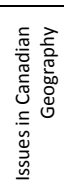 & Applied & CGC1P & $\begin{array}{l}\text { E. Livable } \\
\text { Communities }\end{array}$ & Specific & $\mathrm{E} 3.2$ & $\begin{array}{l}\text { E3.2 describe spatial distribution patterns } \\
\text { for human systems and services in their } \\
\text { community (e.g., infrastructure components, } \\
\text { such as transportation and energy networks, } \\
\text { communication towers, water and waste } \\
\text { facilities) }\end{array}$ & $\mathrm{D}$ & $\mathrm{D}$ \\
\hline 9 & 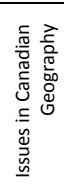 & Applied & CGC1P & $\begin{array}{l}\text { E. Livable } \\
\text { Communities }\end{array}$ & Specific & E3.3 & $\begin{array}{l}\text { E3.3 identify spatial connections between } \\
\text { human systems and services in their } \\
\text { community and the broader regional, } \\
\text { national, and/or global networks to which } \\
\text { they belong (e.g., food distribution, } \\
\text { communications, transportation, and energy } \\
\text { networks) }\end{array}$ & $\mathrm{D}$ & $\mathrm{D}$ \\
\hline 9 & 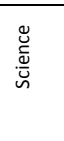 & Academic & SNC1D & $\begin{array}{l}\text { B. Biology: } \\
\text { Sustainable } \\
\text { Ecosystems }\end{array}$ & Overall & B1 & $\begin{array}{l}\text { B1. assess the impact of human activities on } \\
\text { the sustainability of terrestrial and/or } \\
\text { aquatic ecosystems, and evaluate the } \\
\text { effectiveness of courses of action intended } \\
\text { to remedy or mitigate negative impacts; }\end{array}$ & 1 & $\mathrm{~N}$ \\
\hline 9 & $\begin{array}{l}\stackrel{\Xi}{c} \\
. \bar{U} \\
\tilde{n}\end{array}$ & Academic & SNC1D & $\begin{array}{l}\text { B. Biology: } \\
\text { Sustainable } \\
\text { Ecosystems }\end{array}$ & Specific & B1.1 & $\begin{array}{l}\text { B1.1 assess, on the basis of research, the } \\
\text { impact of a factor related to human activity } \\
\text { (e.g., urban sprawl, introduction of invasive } \\
\text { species, overhunting/overfishing) that } \\
\text { threatens the sustainability of a terrestrial or } \\
\text { aquatic eco- system [IP, PR, Al, C] }\end{array}$ & 1 & $\mathrm{~N}$ \\
\hline
\end{tabular}




\begin{tabular}{|c|c|c|c|c|c|c|c|c|c|}
\hline 9 & 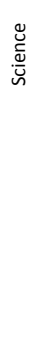 & Academic & SNC1D & $\begin{array}{l}\text { B. Biology: } \\
\text { Sustainable } \\
\text { Ecosystems }\end{array}$ & Specific & B1.2 & $\begin{array}{l}\text { B1.2 evaluate the effectiveness of } \\
\text { government initiatives in Canada (federal, } \\
\text { provincial, municipal), and/or the efforts of } \\
\text { societal groups or non-governmental } \\
\text { organizations, such as Aboriginal } \\
\text { communities, environmental groups, or } \\
\text { student organizations, with respect to an } \\
\text { environmental issue that affects the } \\
\text { sustainability of terrestrial or aquatic } \\
\text { ecosystems (e.g., wetland restoration, } \\
\text { recycling programs, Canada-Ontario } \\
\text { Environmental Farm Plans, stewardship of } \\
\text { national and provincial parks) [Al, C] }\end{array}$ & 1 & $\mathrm{~N}$ \\
\hline 9 & 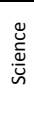 & Academic & SNC1D & $\begin{array}{l}\text { B. Biology: } \\
\text { Sustainable } \\
\text { Ecosystems }\end{array}$ & Overall & B2 & $\begin{array}{l}\text { B2. investigate factors related to human } \\
\text { activity that affect terrestrial and aquatic } \\
\text { ecosystems, and explain how they affect the } \\
\text { sustainability of these ecosystems; }\end{array}$ & 1 & $\mathrm{~N}$ \\
\hline 9 & 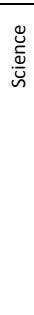 & Academic & SNC1D & $\begin{array}{l}\text { B. Biology: } \\
\text { Sustainable } \\
\text { Ecosystems }\end{array}$ & Specific & B2.3 & $\begin{array}{l}\text { B2.3 plan and conduct an investigation, } \\
\text { involving both inquiry and research, into } \\
\text { how a human activity affects soil } \\
\text { composition or soil fertility (e.g., changes to } \\
\text { soil composition resulting from the use of } \\
\text { different compostable materials, organic or } \\
\text { inorganic fertilizers, or pesticides), and, } \\
\text { extrapolating from the data and information } \\
\text { gathered, explain the impact of this activity } \\
\text { on the sustainability of terrestrial } \\
\text { ecosystems } \\
{[\mathrm{IP}, \mathrm{PR}, \mathrm{Al}, \mathrm{C}]}\end{array}$ & 1 & $\mathrm{~N}$ \\
\hline 9 & 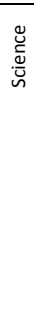 & Academic & SNC1D & $\begin{array}{l}\text { B. Biology: } \\
\text { Sustainable } \\
\text { Ecosystems }\end{array}$ & Specific & B2.4 & $\begin{array}{l}\text { B2.4 plan and conduct an investigation, } \\
\text { involving both inquiry and research, into } \\
\text { how a human activity affects water quality } \\
\text { (e.g., leaching of organic or inorganic } \\
\text { fertilizers or pesticides into water systems, } \\
\text { changes to watersheds resulting from } \\
\text { deforestation or land development, } \\
\text { diversion of ground water for industrial } \\
\text { uses), and, extrapolating from the data and } \\
\text { information gathered, explain the impact of } \\
\text { this activity on the sustainability of aquatic } \\
\text { ecosystems [IP, PR, Al, C] }\end{array}$ & 1 & $\mathrm{~N}$ \\
\hline 9 & 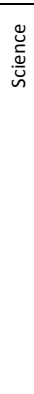 & Academic & SNC1D & $\begin{array}{l}\text { B. Biology: } \\
\text { Sustainable } \\
\text { Ecosystems }\end{array}$ & Specific & B2.5 & $\begin{array}{l}\text { B2.5 analyse the effect of human activity on } \\
\text { the populations of terrestrial and aquatic } \\
\text { ecosystems by interpreting data and } \\
\text { generating graphs (e.g., data from Statistics } \\
\text { Canada, Parks Canada, and other websites } \\
\text { on: the concentration in water of chemicals } \\
\text { from fertilizer run-off and their effect on the } \\
\text { growth of algae; stressors associated with } \\
\text { human use of natural areas, such as } \\
\text { trampled vegetation, wildlife mortality from } \\
\text { motor vehicles, and the removal of plants, } \\
\text { animals, and/or natural objects; suburban } \\
\text { developments and their impact on the food } \\
\text { supply for animals such as foxes and } \\
\text { racoons) [PR, Al, C] }\end{array}$ & 1 & $\mathrm{~N}$ \\
\hline 9 & 选 & Academic & SNC1D & $\begin{array}{l}\text { B. Biology: } \\
\text { Sustainable } \\
\text { Ecosystems }\end{array}$ & Overall & B3 & $\begin{array}{l}\text { B3. demonstrate an understanding of the } \\
\text { dynamic nature of ecosystems, particularly } \\
\text { in terms of ecological balance and the } \\
\text { impact of human activity on the } \\
\text { sustainability of terrestrial and aquatic } \\
\text { ecosystems. }\end{array}$ & 1 & $\mathrm{~N}$ \\
\hline
\end{tabular}




\begin{tabular}{|c|c|c|c|c|c|c|c|c|c|}
\hline 9 & 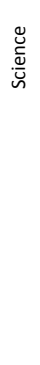 & Academic & SNC1D & $\begin{array}{l}\text { B. Biology: } \\
\text { Sustainable } \\
\text { Ecosystems }\end{array}$ & Specific & B3.2 & $\begin{array}{l}\text { B3.2 describe the complementary processes } \\
\text { of cellular respiration and photosynthesis } \\
\text { with respect to the flow of energy and the } \\
\text { cycling of matter within ecosystems (i.e., } \\
\text { carbon dioxide is a by-product of cellular } \\
\text { respiration and is used for photosynthesis, } \\
\text { which produces oxygen needed for cellular } \\
\text { respiration), and explain how human } \\
\text { activities can disrupt the balance achieved } \\
\text { by these processes (e.g., automobile use } \\
\text { increases the amount of carbon dioxide in } \\
\text { the atmosphere; planting more trees } \\
\text { decreases the amount of carbon dioxide in } \\
\text { the atmosphere) }\end{array}$ & $\mathrm{N}$ & $\mathrm{N}$ \\
\hline 9 & 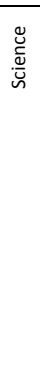 & Academic & SNC1D & $\begin{array}{l}\text { B. Biology: } \\
\text { Sustainable } \\
\text { Ecosystems }\end{array}$ & Specific & B3.5 & $\begin{array}{l}\text { B3.5 identify various factors related to } \\
\text { human activity that have an impact on } \\
\text { ecosystems (e.g., the introduction of } \\
\text { invasive species; shoreline development; } \\
\text { industrial emissions that result in acid rain), } \\
\text { and explain how these factors affect the } \\
\text { equilibrium and survival of ecosystems (e.g., } \\
\text { invasive species push out native species and } \\
\text { upset the equilibrium in an ecosystem; } \\
\text { shoreline development affects the types of } \\
\text { terrestrial and aquatic life that can live near } \\
\text { lake shores or river banks; acid rain changes } \\
\text { the pH of water, which affects the type of } \\
\text { aquatic life that can survive in a lake) }\end{array}$ & 1 & $\mathrm{~N}$ \\
\hline 9 & 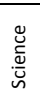 & Academic & SNC1D & $\begin{array}{l}\text { C. Chemistry: } \\
\text { Atoms, } \\
\text { Elements, and } \\
\text { Compounds }\end{array}$ & $\begin{array}{l}\text { Specific } \\
\end{array}$ & $\mathrm{C} 1.2$ & $\begin{array}{l}\text { C1.2 assess social, environmental, and } \\
\text { economic impacts of the use of common } \\
\text { elements or com- pounds [Al, C] }\end{array}$ & $\mathrm{N}$ & $\mathrm{N}$ \\
\hline 9 & 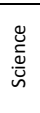 & Applied & SNC1P & $\begin{array}{l}\text { B. Biology: } \\
\text { Sustainable } \\
\text { Ecosystems and } \\
\text { Human Activity }\end{array}$ & Overall & B1 & $\begin{array}{l}\text { B1. analyse the impact of human activity on } \\
\text { terrestrial or aquatic ecosystems, and assess } \\
\text { the effectiveness of selected initiatives } \\
\text { related to environmental sustainability; }\end{array}$ & 1 & $\mathrm{~N}$ \\
\hline 9 & 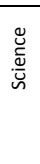 & Applied & SNC1P & $\begin{array}{l}\text { B. Biology: } \\
\text { Sustainable } \\
\text { Ecosystems and } \\
\text { Human Activity }\end{array}$ & Specific & B1.1 & $\begin{array}{l}\text { B1.1 analyse,on the basis of research, how a } \\
\text { human activity (e.g., urban sprawl, , sue of } \\
\text { pesticides and fertilizers, creation of } \\
\text { pollution, human inter- action with wildlife) } \\
\text { threatens the sustainability of a terrestrial or } \\
\text { aquatic ecosystem [IP, PR, Al, C] }\end{array}$ & 1 & $\mathrm{~N}$ \\
\hline 9 & 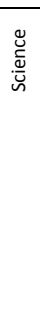 & Applied & SNC1P & $\begin{array}{l}\text { B. Biology: } \\
\text { Sustainable } \\
\text { Ecosystems and } \\
\text { Human Activity }\end{array}$ & Specific & B1.2 & $\begin{array}{l}\text { B1.2 assess the effectiveness of a local } \\
\text { initiative of personal interest that seees to } \\
\text { ensure the sustainability of a terrestrial or } \\
\text { aquatic ecosystem (e.g., greening their } \\
\text { school grounds; conservation } \\
\text { efforts of local Aboriginal communities; } \\
\text { naturalizing banks of local rivers or ponds } \\
\text { with native vegetation; adoption of an } \\
\text { integrated pest management strategy to } \\
\text { combat pests in a local garden), and explain } \\
\text { why the initiative is important to the } \\
\text { sustainability of the ecosystem [Al, C] }\end{array}$ & $\mathrm{N}$ & $\mathrm{D}$ \\
\hline 9 & 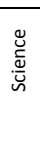 & Applied & SNC1P & $\begin{array}{l}\text { B. Biology: } \\
\text { Sustainable } \\
\text { Ecosystems and } \\
\text { Human Activity }\end{array}$ & Overall & B2 & $\begin{array}{l}\text { B2. investigate some factors related to } \\
\text { human activity that affect terrestrial or } \\
\text { aquatic ecosystems, and describe the } \\
\text { consequences that these factors have for } \\
\text { the sustainability of these ecosystems; }\end{array}$ & 1 & $\mathrm{~N}$ \\
\hline 9 & 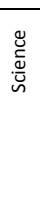 & Applied & SNC1P & $\begin{array}{l}\text { B. Biology: } \\
\text { Sustainable } \\
\text { Ecosystems and } \\
\text { Human Activity }\end{array}$ & Specific & B2.3 & $\begin{array}{l}\text { B2.3 compile and graph qualitative and } \\
\text { quantitative data on organisms within an } \\
\text { undisturbed or disturbed ecosystem } \\
\text { (terrestrial or aquatic) (e.g., nematode and } \\
\text { earthworm populations in soil or compost; } \\
\text { bird populations during migration or winter } \\
\text { feeding; tadpole and mosquito larvae } \\
\text { populations in a local pond) [PR, Al, C] }\end{array}$ & $\mathrm{N}$ & $\mathrm{N}$ \\
\hline
\end{tabular}




\begin{tabular}{|c|c|c|c|c|c|c|c|c|c|}
\hline 9 & 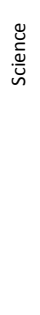 & Applied & SNC1P & $\begin{array}{l}\text { B. Biology: } \\
\text { Sustainable } \\
\text { Ecosystems and } \\
\text { Human Activity }\end{array}$ & Specific & B2.4 & $\begin{array}{l}\text { B2.4 plan and conduct an inquiry into how a } \\
\text { factor related to human activity affects a } \\
\text { terrestrial or aquatic ecosystem (e.g., how } \\
\text { changes to soil composition from the use of } \\
\text { different compost- able materials or organic } \\
\text { or inorganic fertilizers affect the types of } \\
\text { plants that can be grown; how lower water } \\
\text { levels resulting from water di- version affect } \\
\text { waterfowl nesting areas and fish } \\
\text { reproduction), and describe the } \\
\text { consequences that this factor has for the } \\
\text { sustainability of the ecosystem [IP, PR, Al, C] }\end{array}$ & 1 & $\mathrm{~N}$ \\
\hline 9 & 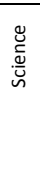 & Applied & SNC1P & $\begin{array}{l}\text { B. Biology: } \\
\text { Sustainable } \\
\text { Ecosystems and } \\
\text { Human Activity }\end{array}$ & Specific & $B 2.5$ & $\begin{array}{l}\text { B2.5 analyse the effect of factors related to } \\
\text { human activity on terrestrial or aquatic } \\
\text { ecosystems by interpreting data and } \\
\text { generating graphs (e.g., data on the } \\
\text { concentration in water of chemicals from } \\
\text { fertilizer run-off and their effect on the } \\
\text { growth of algae) [Al, C] }\end{array}$ & 1 & $\mathrm{~N}$ \\
\hline 9 & 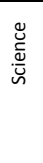 & Applied & SNC1P & $\begin{array}{l}\text { B. Biology: } \\
\text { Sustainable } \\
\text { Ecosystems and } \\
\text { Human Activity }\end{array}$ & $\begin{array}{l}\text { Overall } \\
\end{array}$ & B3 & $\begin{array}{l}\text { B3. demonstrate an understanding of } \\
\text { characteristics of terrestrial and aquatic } \\
\text { ecosystems, the interdependence within and } \\
\text { between ecosystems, and the impact } \\
\text { humans have on the sustainability of these } \\
\text { ecosystems. }\end{array}$ & 1 & $\mathrm{~N}$ \\
\hline 9 & 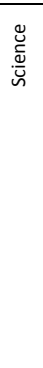 & Applied & SNC1P & $\begin{array}{l}\text { B. Biology: } \\
\text { Sustainable } \\
\text { Ecosystems and } \\
\text { Human Activity }\end{array}$ & Specific & B3.3 & $\begin{array}{l}\text { B3.3 describe the complementary processes } \\
\text { of cellular respiration and photosynthesis } \\
\text { with respect to the flow of energy and the } \\
\text { cycling of matter within ecosystems (e.g., } \\
\text { carbon dioxide is a by-product of cellular } \\
\text { respiration and is used for photosynthesis, } \\
\text { which produces oxygen needed for cellular } \\
\text { respiration), and explain how human } \\
\text { activities can disrupt the balance achieved } \\
\text { by these processes (e.g., automobile use } \\
\text { increases the amount of carbon dioxide in } \\
\text { the atmosphere; planting trees reduces the } \\
\text { amount of carbon dioxide in the } \\
\text { atmosphere) }\end{array}$ & $\mathrm{N}$ & $\mathrm{N}$ \\
\hline 9 & 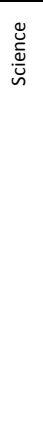 & Applied & SNC1P & $\begin{array}{l}\text { B. Biology: } \\
\text { Sustainable } \\
\text { Ecosystems and } \\
\text { Human Activity }\end{array}$ & $\begin{array}{l}\text { Specific } \\
\end{array}$ & B3.5 & $\begin{array}{l}\text { B3.5 identify some factors related to human } \\
\text { activity that have an immact on ecosystems } \\
\text { (e.g., the use of fertilizers and pesticides; } \\
\text { altered shorelines; organic and conventional } \\
\text { farming; urban sprawl), and explain how } \\
\text { these factors affect the equilibrium and } \\
\text { survival of populations in terrestrial and } \\
\text { aquatic ecosystems (e.g., fertilizers change } \\
\text { the fertility of soil, affecting what types of } \\
\text { plants can grow in it; pesticides leach into } \\
\text { water systems, affecting water quality and } \\
\text { aquatic life; shoreline development affects } \\
\text { the types of aquatic life and terrestrial } \\
\text { vegetation that can live by lake shores or } \\
\text { river banks; urban sprawl wipes out fields } \\
\text { and woods, destroying wildlife habitats) }\end{array}$ & 1 & $\mathrm{~N}$ \\
\hline 9 & 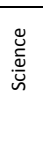 & Applied & SNC1P & $\begin{array}{l}\text { C: Chemistry: } \\
\text { Exploring } \\
\text { Matter }\end{array}$ & Specific & C1.1 & $\begin{array}{l}\text { C1.1 analyse how the chemical and physical } \\
\text { properties of common elements and/or } \\
\text { simple compounds affect the use of } \\
\text { everyday materials that contain those } \\
\text { elements and/or compounds [AI, C] }\end{array}$ & $\mathrm{N}$ & $\mathrm{N}$ \\
\hline 9 & 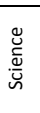 & Applied & SNC1P & $\begin{array}{l}\text { C: Chemistry: } \\
\text { Exploring } \\
\text { Matter }\end{array}$ & Specific & C1.2 & $\begin{array}{l}\text { C1.2 assess the social and environmental } \\
\text { impact of the production or use of a } \\
\text { common element or simple compound [Al, } \\
\text { C] }\end{array}$ & $\mathrm{N}$ & $\mathrm{N}$ \\
\hline 9 & 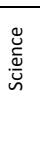 & Applied & SNC1P & $\begin{array}{l}\text { E. Physics: } \\
\text { Electrical } \\
\text { Applications }\end{array}$ & Specific & E2.8 & $\begin{array}{l}\text { E2.8 graph and interpret electricity } \\
\text { consumption data collected over a period of } \\
\text { time from electrical meters at home or in } \\
\text { the community (e.g., their school, a local } \\
\text { community centre) }[\mathrm{PR}, \mathrm{Al}, \mathrm{C}]\end{array}$ & $\mathrm{N}$ & $\mathrm{D}$ \\
\hline
\end{tabular}




\begin{tabular}{|c|c|c|c|c|c|c|c|c|c|}
\hline 10 & 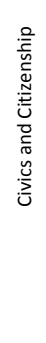 & $\begin{array}{l}\text { Open * half } \\
\text { course }\end{array}$ & $\mathrm{CHV}_{2} \mathrm{O}$ & $\begin{array}{l}\text { A. Political } \\
\text { Inquiry and Skill } \\
\text { Development }\end{array}$ & Specific & A1.1 & $\begin{array}{l}\text { A1.1 formulate different types of questions } \\
\text { to guide investigations into issues, events, } \\
\text { and/or developments of civic importance } \\
\text { (e.g., factual questions: What form of } \\
\text { government does Canada have? What are } \\
\text { my rights and responsibilities as a citizen in } \\
\text { my local community?; comparative } \\
\text { questions: What are the similarities and } \\
\text { differences in the positions of stakeholder } \\
\text { groups on an issue related to local transit in } \\
\text { Ontario?; causal questions: If I were to } \\
\text { implement this plan of action, what impact } \\
\text { might it have on my community?) }\end{array}$ & $\mathrm{N}$ & $N$ \\
\hline 10 & 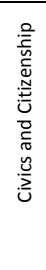 & $\begin{array}{l}\text { Open * half } \\
\text { course }\end{array}$ & $\mathrm{CHV} 2 \mathrm{O}$ & $\begin{array}{l}\text { A. Political } \\
\text { Inquiry and Skill } \\
\text { Development }\end{array}$ & Specific & A1.2 & $\begin{array}{l}\text { A1.2 select and organize relevant evidence, } \\
\text { data, and information on issues, events, } \\
\text { and/or developments of civic importance } \\
\text { from a variety of primary and secondary } \\
\text { sources (e.g., primary sources: interviews, } \\
\text { photographs, podcasts, speeches, statistics, } \\
\text { surveys; secondary sources: investigative } \\
\text { news stories, textbooks, most websites), } \\
\text { ensuring that their sources reflect multiple } \\
\text { perspectives }\end{array}$ & $\mathrm{N}$ & $\mathrm{N}$ \\
\hline 10 & 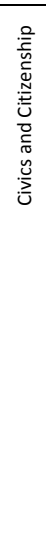 & $\begin{array}{l}\text { Open * half } \\
\text { course }\end{array}$ & $\mathrm{CHV} 2 \mathrm{O}$ & $\begin{array}{l}\text { A. Political } \\
\text { Inquiry and Skill } \\
\text { Development }\end{array}$ & Specific & A1.5 & $\begin{array}{l}\text { A1.5 use the concepts of political thinking } \\
\text { (i.e., political significance, objectives and } \\
\text { results, stability and change, political } \\
\text { perspective) when analysing and evaluating } \\
\text { evidence, data, and information and } \\
\text { formulating conclusions and/or judgments } \\
\text { about issues, events, and/or developments } \\
\text { of civic importance (e.g., use the concept of } \\
\text { political significance when analysing the } \\
\text { impact of the Canadian Charter of Rights and } \\
\text { Freedoms on Canadian society; use the } \\
\text { concept of objectives and results when } \\
\text { analysing the intended and unintended } \\
\text { impact of a community-planning decision; } \\
\text { use the concept of stability and change } \\
\text { when analysing the results of an election; } \\
\text { use the concept of political perspective } \\
\text { when evaluating the positions of different } \\
\text { stakeholder groups on how best to foster } \\
\text { healthy schools and determining the values } \\
\text { and beliefs that underpin these positions) }\end{array}$ & $N$ & $N$ \\
\hline 10 & 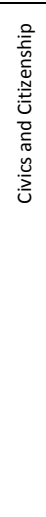 & $\begin{array}{l}\text { Open * half } \\
\text { course }\end{array}$ & CHV2O & $\begin{array}{l}\text { A. Political } \\
\text { Inquiry and Skill } \\
\text { Development }\end{array}$ & Specific & A1.7 & $\begin{array}{l}\text { A1.7 communicate their ideas, arguments, } \\
\text { and conclusions using various formats and } \\
\text { styles, as appropriate for the intended } \\
\text { audiences and purpose (e.g., a blog on the } \\
\text { results of environmental action in their } \\
\text { school; a web page on a social justice } \\
\text { issue such as child poverty and links to } \\
\text { relevant organizations; a discussion group } \\
\text { on how best to foster healthy schools; a } \\
\text { poster that highlights people's civic } \\
\text { responsibilities; a news report on a plan to } \\
\text { build a big box store in the local community; } \\
\text { a presentation on cultural celebrations of } \\
\text { various people within the local community; a } \\
\text { protest song to commemorate or raise } \\
\text { awareness about a violation of human } \\
\text { rights; a petition calling for clean, } \\
\text { safe water on first Nations reserves; a } \\
\text { debate on alternative electoral processes; a } \\
\text { work of art on the value of volunteer work) }\end{array}$ & $N$ & $\mathrm{~N}$ \\
\hline
\end{tabular}




\begin{tabular}{|c|c|c|c|c|c|c|c|c|c|}
\hline 10 & 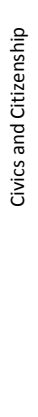 & $\begin{array}{l}\text { Open * half } \\
\text { course }\end{array}$ & CHV2O & $\begin{array}{l}\text { B. Civic } \\
\text { Awareness }\end{array}$ & Specific & B1.1 & $\begin{array}{l}\text { B1.1 describe some civic issues of local, } \\
\text { national, and/or global significance (e.g., } \\
\text { bullying in schools; violence in local } \\
\text { communities; accessibility of buildings in the } \\
\text { local community for people with disabilities; } \\
\text { availability of recreational facilities in the } \\
\text { local community; casino development; voter } \\
\text { turnout; issues related to freedom of } \\
\text { information, taxation, water quality; } \\
\text { Aboriginal treaty rights; the impact of } \\
\text { consumer choices; human rights issues } \\
\text { related to racism, child labour, the rights of } \\
\text { girls or women, homophobia, or classism; } \\
\text { intervention in foreign conflict), and } \\
\text { compare the perspectives of different } \\
\text { groups on selected issues }\end{array}$ & $\mathrm{N}$ & I \\
\hline 10 & 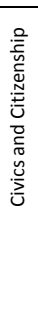 & $\begin{array}{l}\text { Open * half } \\
\text { course }\end{array}$ & $\mathrm{CHV} 2 \mathrm{O}$ & $\begin{array}{l}\text { B. Civic } \\
\text { Awareness }\end{array}$ & Specific & B1.4 & $\begin{array}{l}\text { B1.4 communicate their own position on } \\
\text { some issues of civic importance at the local, } \\
\text { national, and/or global level (e.g., equitable } \\
\text { availability of extracurricular activities in } \\
\text { schools, a local land-use conflict, poverty or } \\
\text { violence in the local community, electoral } \\
\text { reform, the debate over Sharia law in } \\
\text { Ontario, the level of Canada's contribution } \\
\text { to international development assistance, } \\
\text { food security, Aboriginal land rights), } \\
\text { explaining how their position is influenced } \\
\text { by their beliefs/values }\end{array}$ & $\mathrm{N}$ & 1 \\
\hline 10 & 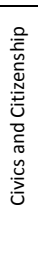 & $\begin{array}{l}\text { Open * half } \\
\text { course }\end{array}$ & CHV2O & $\begin{array}{l}\text { B. Civic } \\
\text { Awareness }\end{array}$ & Specific & B2.2 & $\begin{array}{l}\text { B2.2 explain, with reference to issues of civic } \\
\text { importance, the roles and responsibilities of } \\
\text { different levels of government in Canada } \\
\text { (e.g., federal, provincial and territorial, } \\
\text { municipal, Aboriginal governments) and of } \\
\text { key figures at each level (e.g., members of } \\
\text { Parliament [MPs], senators, members of } \\
\text { provincial Parliament [MPPs], premiers, } \\
\text { mayors, municipal councillors, chiefs, band } \\
\text { councillors, Métis Senators) }\end{array}$ & $\mathrm{D}$ & $\mathrm{N}$ \\
\hline 10 & 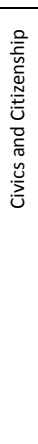 & $\begin{array}{l}\text { Open * half } \\
\text { course }\end{array}$ & $\mathrm{CHV} 2 \mathrm{O}$ & $\begin{array}{l}\text { C. Civic } \\
\text { Engagment and } \\
\text { Action }\end{array}$ & Specific & $\mathrm{C} 1.2$ & $\begin{array}{l}\text { C1.2 describe a variety of ways in which they } \\
\text { could make a civic contribution at the local, } \\
\text { national, and/or global level (e.g., by serving } \\
\text { on student council or on an organization } \\
\text { offering support to students who are being } \\
\text { bullied; by reducing the amount of solid } \\
\text { waste they generate and by properly } \\
\text { disposing of hazardous waste; } \\
\text { by volunteering at a food bank, retirement } \\
\text { home, hospital, humane society, or } \\
\text { recreational facility in the local community; } \\
\text { by donating blood; by participating in } \\
\text { community clean-up or tree-planting days; } \\
\text { by raising funds for a charity or a } \\
\text { development NGO; by writing to or speaking } \\
\text { with their city or band councillor, MPP, or } \\
\text { MP to request action on an issue) }\end{array}$ & $\mathrm{N}$ & 1 \\
\hline 10 & 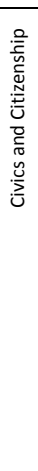 & $\begin{array}{l}\text { Open * half } \\
\text { course }\end{array}$ & $\mathrm{CHV} 2 \mathrm{O}$ & $\begin{array}{l}\text { C. Civic } \\
\text { Engagment and } \\
\text { Action }\end{array}$ & Specific & $\mathrm{C} 1.3$ & $\begin{array}{l}\text { C1.3 explain how various actions can } \\
\text { contribute to the common good at the local, } \\
\text { national, and/ or global level (e.g., engaging } \\
\text { in a non-violent protest can heighten } \\
\text { awareness of an issue and pressure for } \\
\text { change; buying fair trade products helps } \\
\text { ensure that producers are fairly } \\
\text { compensated for the products they produce; } \\
\text { the organized boycotting of products can } \\
\text { pressure corporations to change } \\
\text { irresponsible practices; donating to a } \\
\text { development NGO can help improve the } \\
\text { lives of people affected by a natural disaster } \\
\text { or enhance health care in developing } \\
\text { countries; canvassing or fundraising for an } \\
\text { organization that works for social justice can } \\
\text { raise people's awareness of issues related to } \\
\text { inequity or human rights abuses) }\end{array}$ & $\mathrm{N}$ & $\mathrm{I}$ \\
\hline
\end{tabular}




\begin{tabular}{|c|c|c|c|c|c|c|c|c|c|}
\hline 10 & 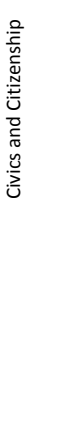 & $\begin{array}{l}\text { Open * half } \\
\text { course }\end{array}$ & $\mathrm{CHV}_{2} \mathrm{O}$ & $\begin{array}{l}\text { C. Civic } \\
\text { Engagment and } \\
\text { Action }\end{array}$ & Specific & C2.1 & $\begin{array}{l}\text { C2.1 analyse ways in which various beliefs, } \\
\text { values, and perspectives are represented in } \\
\text { their communities (e.g., with reference to } \\
\text { different racial, ethnic, and/or religious } \\
\text { groups; people } \\
\text { with various political beliefs and/or social } \\
\text { values; people from different age groups; } \\
\text { men and women; First Nations, Inuit, or } \\
\text { Métis people; people in lesbian, gay, } \\
\text { bisexual, and transgender [LGT] } \\
\text { communities; environmentalists; people } \\
\text { with disabilities; people from different } \\
\text { professions and/or economic circumstances; } \\
\text { recent immigrants and new Canadians; } \\
\text { business people), and assess whether all } \\
\text { perspectives are represented or are valued } \\
\text { equally }\end{array}$ & $\mathrm{N}$ & $\mathrm{N}$ \\
\hline 10 & 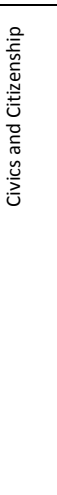 & $\begin{array}{l}\text { Open * half } \\
\text { course }\end{array}$ & $\mathrm{CHV} 2 \mathrm{O}$ & $\begin{array}{l}\text { C. Civic } \\
\text { Engagment and } \\
\text { Action }\end{array}$ & Specific & C2.3 & $\begin{array}{l}\text { C2.3 describe various ways in which people } \\
\text { can access information about civic matters } \\
\text { (e.g., websites of governments, political } \\
\text { parties, NGOs, or other groups and/or } \\
\text { institutions; social media; meetings } \\
\text { organized by elected representatives; } \\
\text { newspapers or newscasts, and assess the } \\
\text { effectiveness of ways in which individuals } \\
\text { can voice their opinions on these matters } \\
\text { (e.g., by contacting their elected } \\
\text { representatives, being part of a delegation } \\
\text { to speak on an issue under consideration by } \\
\text { city council, organizing a petition, voting, } \\
\text { making a presentation to a commmission of } \\
\text { inquiry, participating in a political party or } \\
\text { interest group; by expressing their views } \\
\text { through the media, including social media, } \\
\text { or a a town-hall meeting; through court } \\
\text { challenges; through art, drama, or music) }\end{array}$ & $N$ & $N$ \\
\hline 10 & 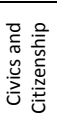 & $\begin{array}{l}\text { Open * half } \\
\text { course }\end{array}$ & CHV2O & $\begin{array}{l}\text { C. Civic } \\
\text { Engagment and } \\
\text { Action }\end{array}$ & $\begin{array}{l}\text { Specific } \\
\end{array}$ & C3.2 & $\begin{array}{l}\text { C3.2 propose different courses of action that } \\
\text { could be used to address a specific civic } \\
\text { issue (e.g., a public awareness campaign, a } \\
\text { plan for local action, a campaign to pressure } \\
\text { for political action), and assess their merits }\end{array}$ & $\mathrm{N}$ & $\mathrm{N}$ \\
\hline 10 & 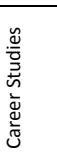 & Open & GLC2O & $\begin{array}{l}\text { Preparation for } \\
\text { Transitions and } \\
\text { Change }\end{array}$ & Specific & & $\begin{array}{l}\text { - articulate personal, learning, community, } \\
\text { and occupational goals, taking into } \\
\text { consideration the results from their personal } \\
\text { profile and their exploration of selected } \\
\text { occupations; }\end{array}$ & $N$ & 1 \\
\hline 10 & 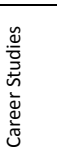 & Open & GLC2O & $\begin{array}{l}\text { Preparation for } \\
\text { Transitions and } \\
\text { Change }\end{array}$ & Specific & & $\begin{array}{l}\text { - produce a preliminary career plan that } \\
\text { identifies secondary school courses, } \\
\text { activities in the school and community, and } \\
\text { postsecondary education options that will } \\
\text { help them achieve their goals; }\end{array}$ & $N$ & I \\
\hline 10 & 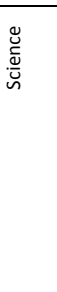 & Academic & SNC2D & $\begin{array}{l}\text { D. Earth and } \\
\text { Space Science: } \\
\text { Climate Change }\end{array}$ & Specific & D1.1 & $\begin{array}{l}\text { D1.1 analyse current and/or potential } \\
\text { effects, both positive and negative, of } \\
\text { climate change on human activity and } \\
\text { natural systems (e.g., loss of habitat for } \\
\text { Arctic mammals such as polar bears and loss } \\
\text { of traditional lifestyles for Inuit as Arctic ice } \\
\text { shrinks; famine as arable land is lost to } \\
\text { desertification; an increase in water-borne } \\
\text { disease and human resettlement as coastal } \\
\text { lands are flooded; expansion of the growing } \\
\text { season in some regions) [Al, C] }\end{array}$ & $N$ & $\mathrm{~N}$ \\
\hline
\end{tabular}




\begin{tabular}{|c|c|c|c|c|c|c|c|c|c|}
\hline 10 & 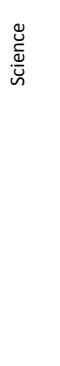 & Academic & SNC2D & $\begin{array}{l}\text { D. Earth and } \\
\text { Space Science: } \\
\text { Climate Change }\end{array}$ & Specific & D1.2 & $\begin{array}{l}\text { D1.2 assess, on the basis of research, the } \\
\text { effective- ness of some current individual, } \\
\text { regional, national, or international initiatives } \\
\text { that address the issue of climate change } \\
\text { (e.g., Drive Clean, ENERGY STAR, federal and } \\
\text { provincial government rebates for } \\
\text { retrofitting older buildings to be more } \\
\text { energy efficient, carbon offset programs, } \\
\text { community tree-planting programs, } \\
\text { municipal recycling programs, } \\
\text { Intergovernmental Panel on Climate Change } \\
\text { [IPCC]), and propose a further course of } \\
\text { action related to one of these initiatives [PR, } \\
\text { Al, C] }\end{array}$ & $\mathrm{N}$ & 1 \\
\hline 10 & 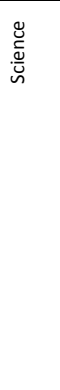 & Academic & SNC2D & $\begin{array}{l}\text { D. Earth and } \\
\text { Space Science: } \\
\text { Climate Change }\end{array}$ & Specific & D2.4 & $\begin{array}{l}\text { D2.4 investigate a popular hypothesis on a } \\
\text { cause- and-effect relationship having to do } \\
\text { with climate change (e.g., the combustion of } \\
\text { fossil fuels is responsible for rising global } \\
\text { temperatures; the concentration of } \\
\text { atmospheric } \mathrm{CO} 2 \text { is responsible for rising } \\
\text { global temperatures; global temperatures } \\
\text { have been on the increase since the } \\
\text { industrial revolution; the severity of } \\
\text { cyclones, hurricanes, and tornadoes } \\
\text { increases as atmospheric temperatures } \\
\text { increase), using simulations and/or time- } \\
\text { trend data that model climate pro- files (e.g., } \\
\text { data from Statistics Canada and } \\
\text { Environment Canada) [PR, Al, C] }\end{array}$ & $\mathrm{N}$ & $\mathrm{N}$ \\
\hline 10 & 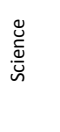 & Academic & SNC2D & $\begin{array}{l}\text { D. Earth and } \\
\text { Space Science: } \\
\text { Climate Change }\end{array}$ & Specific & D2.8 & $\begin{array}{l}\text { D2.8 classify the climate of their local region } \\
\text { using various tools or systems (e.g., } \\
\text { Ecoregions of Canada, bioclimate profiles), } \\
\text { and compare their region to other regions in } \\
\text { Ontario, Canada, and the world }[\mathrm{Al}, \mathrm{C}]\end{array}$ & $N$ & D \\
\hline 10 & 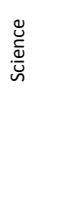 & Academic & SNC2D & $\begin{array}{l}\text { D. Earth and } \\
\text { Space Science: } \\
\text { Climate Change }\end{array}$ & Specific & D3.4 & $\begin{array}{l}\text { D3.4 identify natural phenomena (e.g., plate } \\
\text { tectonics, uplift and weathering, solar } \\
\text { radiance, cosmic ray cycles) and human } \\
\text { activities (e.g., forest fires, deforestation, } \\
\text { the burning of fossil fuels, industrial } \\
\text { emissions) known to affect cli- mate, and } \\
\text { describe the role of both in Canada's } \\
\text { contribution to climate change }\end{array}$ & $\mathrm{N}$ & $\mathrm{N}$ \\
\hline 10 & 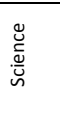 & Applied & SNC2P & $\begin{array}{l}\text { D. Earth and } \\
\text { Space Science: } \\
\text { Earth's } \\
\text { Dynamic } \\
\text { Climate }\end{array}$ & Specific & D1.2 & $\begin{array}{l}\text { D1.2 analyse ways in which human actions } \\
\text { (e.g., burning fossil fuels, implementing tree- } \\
\text { planting programs) have increased or } \\
\text { decreased the production of greenhouse } \\
\text { gases }[\mathrm{Al}, \mathrm{C}]\end{array}$ & $\mathrm{N}$ & $\mathrm{N}$ \\
\hline$* 11$ & 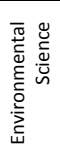 & Workplace & SVN3E & $\begin{array}{l}\text { B: Human } \\
\text { Impact on the } \\
\text { Environment }\end{array}$ & Overall & B1 & $\begin{array}{l}\text { B1. analyse selected current environmental } \\
\text { problems in terms of the role human } \\
\text { activities have played in creating or } \\
\text { perpetuating them, and propose possible } \\
\text { solutions to one such problem; }\end{array}$ & 1 & $\mathrm{~N}$ \\
\hline$* 11$ & 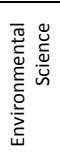 & Workplace & SVN3E & $\begin{array}{l}\text { B: Human } \\
\text { Impact on the } \\
\text { Environment }\end{array}$ & Specific & B1.1 & $\begin{array}{l}\text { B1.1 propose possible solutions, on the basis } \\
\text { of research, to a current practical } \\
\text { environmental problem that is caused, } \\
\text { directly or indirectly, by human activities [IP, } \\
\mathrm{PR}, \mathrm{Al}, \mathrm{C}]\end{array}$ & I & $\mathrm{N}$ \\
\hline$* 11$ & 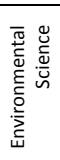 & Workplace & SVN3E & $\begin{array}{l}\text { B: Human } \\
\text { Impact on the } \\
\text { Environment }\end{array}$ & Specific & B1.2 & $\begin{array}{l}\text { B1.2 analyse the risks and benefits to the } \\
\text { environment of human recreational } \\
\text { activities and the leisure industry }[\mathrm{Al}, \mathrm{C}]\end{array}$ & 1 & $\mathrm{~N}$ \\
\hline
\end{tabular}




\begin{tabular}{|c|c|c|c|c|c|c|c|c|c|}
\hline$* 11$ & 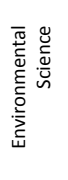 & Workplace & SVN3E & $\begin{array}{l}\text { B: Human } \\
\text { Impact on the } \\
\text { Environment }\end{array}$ & Specific & B2.4 & $\begin{array}{l}\text { B2.4 analyse and interpret data on } \\
\text { particulate matter in air samples from } \\
\text { several different regions of Canada, using } \\
\text { prepared data from a variety of sources } \\
\text { (e.g., the Ontario Ministry of the } \\
\text { Environment - Air Quality Ontario, } \\
\text { Environment Canada) [Al] }\end{array}$ & 1 & $\mathrm{~N}$ \\
\hline$*^{*} 11$ & 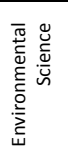 & Workplace & SVN3E & $\begin{array}{l}\text { B: Human } \\
\text { Impact on the } \\
\text { Environment }\end{array}$ & Overall & B3 & $\begin{array}{l}\text { B3. demonstrate an understanding of some } \\
\text { of the ways in which human activities affect } \\
\text { the environment and how the impact of } \\
\text { those activities is measured and monitored. }\end{array}$ & 1 & $\mathrm{~N}$ \\
\hline${ }^{*} 11$ & 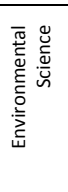 & Workplace & SVN3E & $\begin{array}{l}\text { B: Human } \\
\text { Impact on the } \\
\text { Environment }\end{array}$ & Specific & B3.1 & $\begin{array}{l}\text { B3.1 identify the basic components of soil, } \\
\text { water, and air, and describe some of the } \\
\text { effects of human activity on soil, water, and } \\
\text { air quality (e.g., the effects of industrial or } \\
\text { vehicle emissions on air quality; of chemical } \\
\text { spills on soil quality; of chlorination on water } \\
\text { quality) }\end{array}$ & 1 & $\mathrm{~N}$ \\
\hline$*^{* 11}$ & 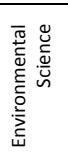 & Workplace & SVN3E & $\begin{array}{l}\text { B: Human } \\
\text { Impact on the } \\
\text { Environment }\end{array}$ & Specific & B3.5 & $\begin{array}{l}\text { B3.5 explain the effects of human activity on } \\
\text { an aquatic or terrestrial ecosystem (e.g., the } \\
\text { impact of fertilizer run-off, acid } \\
\text { precipitation, or an oil spill on an aquatic } \\
\text { ecosystem) }\end{array}$ & 1 & $\mathrm{~N}$ \\
\hline${ }^{*}+11$ & 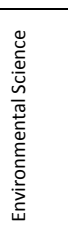 & Workplace & SVN3E & $\begin{array}{l}\text { B: Human } \\
\text { Impact on the } \\
\text { Environment }\end{array}$ & Specific & B3.6 & $\begin{array}{l}\text { B3.6 explain how human activities (e.g., } \\
\text { agriculture, travel, the purchase of exotic } \\
\text { pets, importing and exporting, releasing } \\
\text { domesticated fish into fresh water } \\
\text { environments, the use of live bait) have led } \\
\text { to the introduction of invasive species, and } \\
\text { why it is important to measure and monitor } \\
\text { the impact of invasive species on native } \\
\text { species }\end{array}$ & 1 & $\mathrm{~N}$ \\
\hline${ }^{*} 11$ & 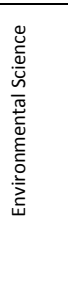 & Workplace & SVN3E & $\begin{array}{l}\text { B: Human } \\
\text { Impact on the } \\
\text { Environment }\end{array}$ & Specific & $B 2.2$ & $\begin{array}{l}\text { B2.2 plan and conduct an inquiry, using } \\
\text { appropriate technology, to compare soil } \\
\text { quality in natural and disturbed } \\
\text { environments (e.g., compare the } \\
\text { phosphorous content, pH, organic matter } \\
\text { con- tent, water content, water-holding } \\
\text { capacity, nutrient content, porosity, and/or } \\
\text { bulk density of soil from a forest or meadow } \\
\text { and soil from a garden or farmer's field that } \\
\text { has been treated with chemical fertilizer) [IP, } \\
\text { PR, Al] }\end{array}$ & $N$ & $\mathrm{D}$ \\
\hline${ }^{*} 11$ & 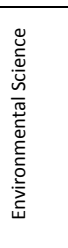 & Workplace & SVN3E & $\begin{array}{l}\text { B: Human } \\
\text { Impact on the } \\
\text { Environment }\end{array}$ & Specific & B2.3 & $\begin{array}{l}\text { B2.3 plan and conduct an inquiry, using } \\
\text { appropriate technology, to compare water } \\
\text { quality in natural and disturbed } \\
\text { environments (e.g., com- pare the pH, ion } \\
\text { content, temperature, dissolved oxygen } \\
\text { content, hardness, turbidity, biological } \\
\text { oxygen demand [BOD], and/or fecal coliform } \\
\text { of tap water, water from a pond or stream, } \\
\text { and water from a drainage ditch) [IP, PR, AI] }\end{array}$ & $\mathrm{N}$ & $\mathrm{D}$ \\
\hline${ }^{*}+11$ & 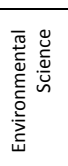 & Workplace & SVN3E & $\begin{array}{l}\text { B: Human } \\
\text { Impact on the } \\
\text { Environment }\end{array}$ & Specific & B2.5 & $\begin{array}{l}\text { B2.5 plan and conduct a waste audit of their } \\
\text { home or school [IP, PR] }\end{array}$ & $\mathrm{N}$ & $\mathrm{D}$ \\
\hline *11 & 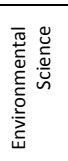 & Workplace & SVN3E & $\begin{array}{l}\text { C. Human } \\
\text { Health and the } \\
\text { Environment }\end{array}$ & Overall & $\mathrm{C} 1$ & $\begin{array}{l}\text { C1. analyse the effects on human health of } \\
\text { environmental contaminants and a } \\
\text { significant environmental phenomenon; }\end{array}$ & 1 & $\mathrm{~N}$ \\
\hline
\end{tabular}




\begin{tabular}{|c|c|c|c|c|c|c|c|c|c|}
\hline$* 11$ & 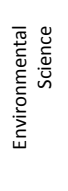 & Workplace & SVN3E & $\begin{array}{l}\text { C. Human } \\
\text { Health and the } \\
\text { Environment }\end{array}$ & Specific & $\mathrm{C} 1.2$ & $\begin{array}{l}\text { C1.2 analyse how environmental } \\
\text { contaminants can affect the health of } \\
\text { different populations in Canada (e.g., } \\
\text { mercury contamination in streams and rivers } \\
\text { in Northern Ontario where Aboriginal people } \\
\text { fish, toxins in Arctic sea mammals hunted by } \\
\text { Inuit, smog in large cities) [Al, C] }\end{array}$ & 1 & $\mathrm{~N}$ \\
\hline$* 11$ & 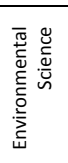 & Workplace & SVN3E & $\begin{array}{l}\text { C. Human } \\
\text { Health and the } \\
\text { Environment }\end{array}$ & Overall & $\mathrm{C} 2$ & $\begin{array}{l}\text { C2. investigate how different environmental } \\
\text { factors can affect people's health and their } \\
\text { lifestyle choices; }\end{array}$ & 1 & $\mathrm{~N}$ \\
\hline${ }^{*} 11$ & 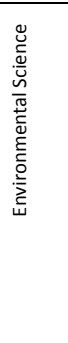 & Workplace & SVN3E & $\begin{array}{l}\text { C. Human } \\
\text { Health and the } \\
\text { Environment }\end{array}$ & Specific & C2.2 & $\begin{array}{l}\text { C2.2 investigate, using a research process, } \\
\text { and re- port on an environmental factor that } \\
\text { can have an impact on human health (e.g., } \\
\text { smog, ultraviolet [UV] rays, bacteria, } \\
\text { pesticide residue), and ex- plain how their } \\
\text { personal lifestyle choices can affect its } \\
\text { impact (e.g., avoiding strenuous physical } \\
\text { activity on days when there is a smog alert } \\
\text { can reduce the severity of respiratory } \\
\text { ailments; lying on the beach without } \\
\text { sunscreen or sun protective clothing during } \\
\text { peak UV hours can increase the risk of skin } \\
\text { cancer) [IP, PR, Al, C] }\end{array}$ & 1 & $\mathrm{~N}$ \\
\hline$* 11$ & 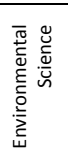 & Workplace & SVN3E & $\begin{array}{l}\text { C. Human } \\
\text { Health and the } \\
\text { Environment }\end{array}$ & Overall & $\mathrm{C3}$ & $\begin{array}{l}\text { C3. demonstrate an understanding of the } \\
\text { ways in which environmental factors can } \\
\text { affect human health and how their impact } \\
\text { can be reduced. }\end{array}$ & 1 & $\mathrm{~N}$ \\
\hline$* 11$ & 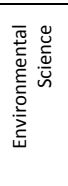 & Workplace & SVN3E & $\begin{array}{l}\text { C. Human } \\
\text { Health and the } \\
\text { Environment }\end{array}$ & Specific & C3.1 & $\begin{array}{l}\text { C3.1 describe common environmental } \\
\text { factors, including pollution and } \\
\text { environmental contaminants (e.g., air, noise, } \\
\text { soil, and water pollution; UV rays; heat; } \\
\text { heavy metals; work- place chemicals; } \\
\text { pathogens), and explain how they can affect } \\
\text { human health }\end{array}$ & 1 & $\mathrm{~N}$ \\
\hline$* 11$ & 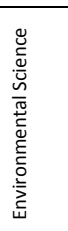 & Workplace & SVN3E & $\begin{array}{l}\text { D. Energy } \\
\text { Conservation }\end{array}$ & $\begin{array}{l}\text { Specific } \\
\end{array}$ & D1.1 & $\begin{array}{l}\text { D1.1 assess, on the basis of research, the } \\
\text { impact that initiatives for reducing energy } \\
\text { consumption and waste have on personal } \\
\text { lifestyles, societal attitudes, and the } \\
\text { environment (e.g., local, provincial, or } \\
\text { national initiatives by government, business, } \\
\text { or non-governmental organizations) [IP, PR, } \\
\text { Al, C] }\end{array}$ & 1 & $\mathrm{~N}$ \\
\hline$* 11$ & 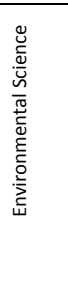 & Workplace & SVN3E & $\begin{array}{l}\text { D. Energy } \\
\text { Conservation }\end{array}$ & Specific & D3.3 & $\begin{array}{l}\text { D3.3 describe methods of energy } \\
\text { conservation (e.g., the replacement of } \\
\text { incandescent bulbs with compact } \\
\text { fluorescent bulbs, the replacement of a } \\
\text { manual thermostat with a programmable } \\
\text { one, the installation of more energy-efficient } \\
\text { windows) and some policies that are } \\
\text { intended to manage energy demand in the } \\
\text { home and the workplace (e.g., variable } \\
\text { pricing, which increases the price of } \\
\text { electricity during peak hours) }\end{array}$ & 1 & $\mathrm{~N}$ \\
\hline$* 11$ & 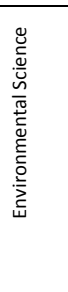 & Workplace & SVN3E & $\begin{array}{l}\text { E. Natural } \\
\text { Resource } \\
\text { Science and } \\
\text { Management }\end{array}$ & Specific & E2.3 & $\begin{array}{l}\text { E2.3 investigate, through laboratory inquiry, } \\
\text { field study, or simulations, some of the } \\
\text { methods and procedures used by scientists } \\
\text { to monitor bio- diversity in different } \\
\text { environments (e.g., making plant tallies in } \\
\text { forests; tagging or marking ground } \\
\text { vegetation species in fields; tagging and } \\
\text { tracking wildlife with the global positioning } \\
\text { system in remote areas; using aquatic dip } \\
\text { nets for sampling organisms in shallow } \\
\text { ponds or streams) [PR] }\end{array}$ & $\mathrm{N}$ & 1 \\
\hline
\end{tabular}




\begin{tabular}{|c|c|c|c|c|c|c|c|c|c|}
\hline$* 11$ & 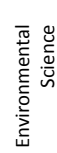 & Workplace & SVN3E & $\begin{array}{l}\text { E. Natural } \\
\text { Resource } \\
\text { Science and } \\
\text { Management }\end{array}$ & Specific & E2.4 & $\begin{array}{l}\text { E2.4 conduct an inventory of a local } \\
\text { environment (e.g., a field, a pond), using } \\
\text { appropriate techniques and methods (e.g., } \\
\text { plant tallies, tags, keys), and display the } \\
\text { results graphically [PR, C] }\end{array}$ & $\mathrm{N}$ & D \\
\hline
\end{tabular}

\begin{tabular}{|c|c|c|c|c|}
\hline 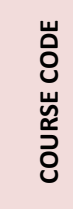 & 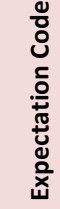 & EXAMPLES (only if they contain reference to U/PB EE) & $\begin{array}{l}\text { Examples } \\
\text { Urban EE } \\
\text { (Direct } \\
\text { /Indirect / } \\
\text { None) }\end{array}$ & $\begin{array}{l}\text { Place- } \\
\text { Based EE } \\
\text { (Direct / } \\
\text { Indirect / } \\
\text { None) }\end{array}$ \\
\hline CGC1D & A1.1 & $\begin{array}{l}\text { e.g. Factual questions: What factors need to be considered when analysing the impact of expanding a } \\
\text { highway?; How does the infrastructure of this community support environmental sustainability? }\end{array}$ & $\mathrm{D}$ & $\mathrm{I}$ \\
\hline CGC1D & A1.5 & $\begin{array}{l}\text { e.g. use the concept of spatial significance to evaluate competing land-use options, such as fruit } \\
\text { farming and urban development; apply the concept of patterns and trends to temperature } \\
\text { and precipitation data to assess how the climate of a region has changed over time; use the concept of } \\
\text { interrelationships to assess how changes in technology affect industry, employment, and the } \\
\text { consumption of natural resources; }\end{array}$ & $\mathrm{D}$ & $\mathrm{N}$ \\
\hline CGC1D & A1.6 & & $\mathrm{N}$ & $\mathrm{N}$ \\
\hline CGC1D & A2.3 & & $\mathrm{N}$ & $\mathrm{N}$ \\
\hline CGC1D & B1.2 & water bodies and flat land facilitate urban development and transportation & $\mathrm{D}$ & $\mathrm{N}$ \\
\hline CGC1D & B1.3 & & $\mathrm{N}$ & $\mathrm{N}$ \\
\hline CGC1D & B1.4 & $\begin{array}{l}\text { e.g., paving over land can alter drainage patterns and cause sink holes; some agricultural practices can } \\
\text { contribute to soil erosion; deforestation can make slopes vulnerable to landslides }\end{array}$ & 1 & $\mathrm{~N}$ \\
\hline CGC1D & B3.2 & & $\mathrm{N}$ & $\mathrm{N}$ \\
\hline CGC1D & $\mathrm{C} 1.1$ & $\begin{array}{l}\text { e.g., green belts, tourism restrictions in environment- ally fragile regions, wildlife culling, rehabilitation } \\
\text { of aggregate quarries, sustainable yield management of forests and fisheries, recovery of minerals } \\
\text { from mine tailings, community composting, recycling and recovery }\end{array}$ & $\mathrm{D}$ & $\mathrm{N}$ \\
\hline CGC1D & $\mathrm{C} 2.4$ & & $\mathrm{~N}$ & $\mathrm{~N}$ \\
\hline CGC1D & C3.4 & $\begin{array}{l}\text { e.g., availability of resources, distance to market, transportation costs, government incentives, labour } \\
\text { force e.g., resource extraction industries, manufacturing industries, service industries, knowledge- } \\
\text { based industries, cultural industries }\end{array}$ & 1 & $\mathrm{~N}$ \\
\hline CGC1D & D1.1 & $\begin{array}{l}\text { e.g., aging population increases demand for health care and institutional support; increasing } \\
\text { population density affects housing, job, and transportation needs; increased number of working } \\
\text { parents with responsibilities for both child and elder care affects family life and housing needs; } \\
\text { neighbourhoods that consist largely of a single ethnic or cultural group pose challenges to social } \\
\text { integration; growth of First Nations, Métis, and Inuit populations increases need for education, } \\
\text { housing, health care, infrastructure, and resolution of land claims and rights disputes } \\
\text { e.g., aging population will further increase demand for health care, retirement housing, and transit } \\
\text { support; increased diversity of newcomers will increase demand for language training }\end{array}$ & $D$ & $\mathrm{~N}$ \\
\hline CGC1D & $\mathrm{D} 2.1$ & $\begin{array}{l}\text { e.g., expansion of business opportunities, cultural enrichment, global engagement and citizenship; } \\
\text { neighbourhood segregation and lack of social integration, hate crimes }\end{array}$ & $\mathrm{I}$ & $\mathrm{N}$ \\
\hline CGC1D & $\mathrm{D} 2.2$ & & $\mathrm{~N}$ & $\mathrm{~N}$ \\
\hline CGC1D & $\mathrm{D} 2.3$ & & $\mathrm{~N}$ & $\mathrm{~N}$ \\
\hline
\end{tabular}




\begin{tabular}{|c|c|c|c|c|}
\hline CGC1D & D3.2 & $\begin{array}{l}\text { e.g., job opportunities, accessibility of transportation and communication networks, availability of } \\
\text { social services, availability of natural resources, cultural attitudes }\end{array}$ & D & $\mathrm{N}$ \\
\hline CGC1D & D3.3 & & $\mathrm{N}$ & $\mathrm{N}$ \\
\hline CGC1D & D3.4 & & $\mathrm{N}$ & $\mathrm{N}$ \\
\hline CGC1D & D3.5 & $\begin{array}{l}\text { e.g., increase in First Nations, Métis, and Inuit peoples moving into urban centres, rural residents } \\
\text { moving to urban centres, people from central and eastern provinces moving to northern Alberta and } \\
\text { the Northwest Territories }\end{array}$ & $\mathrm{D}$ & $\mathrm{N}$ \\
\hline CGC1D & D3.1 & $\begin{array}{l}\text { e.g., landforms; climate; proximity to food and water sources; connections to transportation, } \\
\text { communications, energy, and economic networks }\end{array}$ & $\mathrm{D}$ & $\mathrm{N}$ \\
\hline CGC1D & $\mathrm{E} 2.2$ & $\begin{array}{l}\text { e.g., cost of expanding infrastructure and public services; health impacts, such as faster spread of } \\
\text { disease in densely populated communities, increases in asthma attacks as a result of poor air quality, } \\
\text { and stress related to crowding; traffic congestion and related economic costs; conflict over } \\
\text { development priorities }\end{array}$ & $\mathrm{D}$ & $\mathrm{N}$ \\
\hline CGC1D & E1.2 & $\begin{array}{l}\text { e.g., widening highways, creating high occupancy vehicle lanes, creating bike lanes, improving mass } \\
\text { transit infrastructure, upgrading train corridors, opening the Northwest Passage to international } \\
\text { shipping }\end{array}$ & $\mathrm{D}$ & $\mathrm{N}$ \\
\hline CGC1D & $\mathrm{E} 2.1$ & e.g., impact of urban sprawl, vehicle use, and waste disposal on water and air quality & $\mathrm{D}$ & $\mathrm{N}$ \\
\hline CGC1D & E2 & & $\mathrm{N}$ & $\mathrm{N}$ \\
\hline CGC1D & $\mathrm{E} 3.1$ & $\begin{array}{l}\text { e.g., size and distribution of transportation corridors, differences in residential types, location of } \\
\text { industrial land }\end{array}$ & $\mathrm{D}$ & $\mathrm{N}$ \\
\hline CGC1D & E1.1 & & $\mathrm{N}$ & $\mathrm{N}$ \\
\hline CGC1D & E1.4 & $\begin{array}{l}\text { e.g., diversified economy; investment in public services and infrastructure, such as transportation } \\
\text { networks, health and social services, recreational and cultural facilities; educational opportunities; } \\
\text { recognition of heritage; diverse neighbourhoods }\end{array}$ & $\mathrm{I}$ & 1 \\
\hline CGC1D & E1.5 & $\begin{array}{l}\text { e.g., improving community/neighbourhood amenities, establishing local markets, replacing individual } \\
\text { ownership of equipment with cooperative ownership, sharing cars, introducing a rental bike network, } \\
\text { expanding the amount of green space }\end{array}$ & $\mathrm{N}$ & 1 \\
\hline CGC1D & E2.3 & e.g., green belts, high density residential infill, gentrification & $\mathrm{D}$ & $\mathrm{N}$ \\
\hline CGC1D & $\mathrm{E} 3.2$ & e.g., roads tend to be on flatter land; parks are often near water & $\mathrm{D}$ & $\mathrm{N}$ \\
\hline CGC1D & $\mathrm{E} 3.3$ & & $\mathrm{~N}$ & $\mathrm{~N}$ \\
\hline CGC1P & $\mathrm{A} 1.1$ & "How can increasing the use of public transit contribute to better air quality in your community? & $\mathrm{D}$ & $\mathrm{D}$ \\
\hline CGC1P & A1.2 & & $\mathrm{N}$ & $\mathrm{N}$ \\
\hline CGC1P & A1.4 & $\begin{array}{l}\text { e.g., use data about their way of living and use of resources to calculate their ecological footprint and } \\
\text { compare it to the ecological footprints of people in Canada and other parts of the world; use graphic } \\
\text { organizers, such as cross-classification tables or ranking ladders, to interpret the potential economic, } \\
\text { political, social, and/or environmental impacts of an industry that wants to establish itself in their } \\
\text { community }\end{array}$ & $\mathrm{N}$ & $\mathrm{D}$ \\
\hline CGC1P & A.15 & $\begin{array}{l}\text { e.g., use the concept of spatial significance to assess the characteristics of locations for different types } \\
\text { of land use when planning city spaces; use the concept of patterns and trends to analyse the impact of } \\
\text { earthquakes on urban structures; use the concept of interrelationships to guide personal behaviours } \\
\text { that may affect the natural environment; use the concept of geographic perspective to analyse the } \\
\text { environmental, social, political, and/or economic impacts of building a highway or energy pipeline } \\
\text { through the lands of a First Nation, Métis, and/or Inuit community }\end{array}$ & $\mathrm{D}$ & $\mathrm{N}$ \\
\hline CGC1P & A1.6 & & $\mathrm{N}$ & $\mathrm{N}$ \\
\hline CGC1P & A2.3 & & $\mathrm{N}$ & $\mathrm{N}$ \\
\hline CGC1P & B1.4 & $\begin{array}{l}\text { e.g., vehicle use, chimney emissions, and barbecue and lawn mower usage contribute to smog and can } \\
\text { change the acidity of lake water; blasting and drilling may trigger land instability; removing trees and } \\
\text { paving over land change the amount of water going into the soil and back into the air; expansion of } \\
\text { highways can lead to more animals being struck by vehicles and can also disrupt animal migration } \\
\text { patterns and separate animals from their food supplies, thus endangering their populations }\end{array}$ & 1 & $\mathrm{~N}$ \\
\hline CGC1P & B2.2 & & $\mathrm{N}$ & $\mathrm{N}$ \\
\hline CGC1P & B3.1 & & $\mathrm{N}$ & $\mathrm{N}$ \\
\hline CGC1P & B3.2 & & $\mathrm{N}$ & $\mathrm{N}$ \\
\hline CGC1P & C1.1 & & $\mathrm{N}$ & $\mathrm{N}$ \\
\hline
\end{tabular}




\begin{tabular}{|c|c|c|c|c|}
\hline CGC1P & $\mathrm{C} 2.3$ & & $\mathrm{~N}$ & $\mathrm{~N}$ \\
\hline CGC1P & D1.1 & & $\mathrm{N}$ & $\mathrm{N}$ \\
\hline CGC1P & $\mathrm{D} 1.2$ & & $\mathrm{~N}$ & $\mathrm{~N}$ \\
\hline CGC1P & D1.3 & & $\mathrm{N}$ & $\mathrm{N}$ \\
\hline CGC1P & D1.4 & & $\mathrm{N}$ & $\mathrm{N}$ \\
\hline CGC1P & D2.1 & & $\mathrm{N}$ & $\mathrm{N}$ \\
\hline CGC1P & D3.1 & $\begin{array}{l}\text { e.g., towns, cities, census metropolitan areas, megalopolises, First Nations reserves e.g., near rivers, } \\
\text { highways, natural resources }\end{array}$ & $\mathrm{D}$ & $\mathrm{N}$ \\
\hline CGC1P & D3.2 & e.g., population density, growth rate, age-sex distribution, cultural diversity & $\mathrm{D}$ & $\mathrm{N}$ \\
\hline CGC1P & E1.2 & & $\mathrm{N}$ & $\mathrm{N}$ \\
\hline CGC1P & E1.4 & & $\mathrm{N}$ & $\mathrm{N}$ \\
\hline CGC1P & E2.2 & $\begin{array}{l}\text { e.g., land uses that conflict with each other, land uses that make other land uses more efficient or less } \\
\text { efficient }\end{array}$ & $\mathrm{D}$ & D \\
\hline CGC1P & E2.3 & $\begin{array}{l}\text { e.g., new suburban malls can drain business from downtown stores and lead to the decline of a } \\
\text { community's central core; replacing an old industrial district with retail or recreational development, } \\
\text { adding additional transportation } \\
\text { capacity, new cultural institutions, amenities, industrial parks can stimulate growth }\end{array}$ & $\mathrm{D}$ & $\mathrm{N}$ \\
\hline CGC1P & E2.4 & $\begin{array}{l}\text { e.g., residential or resort development, urban renewal, installation of water and waste management } \\
\text { systems, creation of a park or recreational site, addition of bike lanes on major streets, opening of a } \\
\text { mine near a reserve community }\end{array}$ & $\mathrm{D}$ & $\mathrm{N}$ \\
\hline CGC1P & E3 & & $\mathrm{N}$ & $\mathrm{N}$ \\
\hline CGC1P & E3.1 & & $\mathrm{N}$ & $\mathrm{N}$ \\
\hline CGC1P & E3.2 & $\begin{array}{l}\text { e.g., infrastructure components, such as transportation and energy networks, communication towers, } \\
\text { water and waste facilities }\end{array}$ & $\mathrm{D}$ & $\mathrm{D}$ \\
\hline CGC1P & E3.3 & e.g., food distribution, communications, transportation, and energy networks & $\mathrm{D}$ & $\mathrm{D}$ \\
\hline SNC1D & $\mathrm{B} 1$ & & $\mathrm{~N}$ & $\mathrm{~N}$ \\
\hline SNC1D & B1.1 & e.g., urban sprawl, introduction of invasive species, overhunting/overfishing & $\mathrm{D}$ & $\mathrm{N}$ \\
\hline SNC1D & B1.2 & $\begin{array}{l}\text { federal, provincial, municipal e.g., wetland restoration, recycling programs, Canada-Ontario } \\
\text { Environmental Farm Plans, stewardship of national and provincial parks }\end{array}$ & $\mathrm{D}$ & $\mathrm{N}$ \\
\hline SNC1D & B2 & & $\mathrm{N}$ & $\mathrm{N}$ \\
\hline SNC1D & B2.3 & & $\mathrm{N}$ & $\mathrm{N}$ \\
\hline SNC1D & B2.4 & $\begin{array}{l}\text { e.g., leaching of organic or inorganic fertilizers or pesticides into water systems, changes to watersheds } \\
\text { resulting from deforestation or land development, diversion of ground water for industrial uses }\end{array}$ & $\mathrm{I}$ & $\mathrm{N}$ \\
\hline SNC1D & B2.5 & $\begin{array}{l}\text { e.g., data from Statistics Canada, Parks Canada, and other websites on: the concentration in water of } \\
\text { chemicals from fertilizer run-off and their effect on the growth of algae; stressors associated with } \\
\text { human use of natural areas, such as trampled vegetation, wildlife mortality from motor vehicles, and } \\
\text { the removal of plants, animals, and/or natural objects; suburban developments and their impact on } \\
\text { the food supply for animals such as foxes and racoons) }\end{array}$ & $\mathrm{D}$ & $\mathrm{N}$ \\
\hline SNC1D & B3 & & $\mathrm{N}$ & $\mathrm{N}$ \\
\hline SNC1D & B3.2 & $\begin{array}{l}\text { e.g., automobile use increases the amount of carbon dioxide in the atmosphere; planting more trees } \\
\text { decreases the amount of carbon dioxide in the atmosphere }\end{array}$ & I & $\mathrm{N}$ \\
\hline SNC1D & B3.5 & $\begin{array}{l}\text { e.g., invasive species push out native species and upset the equilibrium in an ecosystem; shoreline } \\
\text { development affects the types of terrestrial and aquatic life that can live near lake shores or river } \\
\text { banks; acid rain changes the } \mathrm{pH} \text { of water, which affects the type of aquatic life that can survive in a } \\
\text { lake }\end{array}$ & 1 & $\mathrm{~N}$ \\
\hline SNC1D & $\mathrm{C} 1.2$ & & $\mathrm{~N}$ & $\mathrm{~N}$ \\
\hline SNC1P & B1 & & $\mathrm{N}$ & $N$ \\
\hline SNC1P & B1.1 & $\begin{array}{l}\text { e.g., urban sprawl, use of pesticides and fertilizers, creation of pollution, human inter- action with } \\
\text { wildlife }\end{array}$ & $\mathrm{D}$ & $\mathrm{N}$ \\
\hline SNC1P & B1.2 & $\begin{array}{l}\text { e.g., greening their school grounds; conservation } \\
\text { efforts of local Aboriginal communities; naturalizing banks of local rivers or ponds with native } \\
\text { vegetation; adoption of an integrated pest management strategy to combat pests in a local garden }\end{array}$ & $\mathrm{N}$ & $\mathrm{D}$ \\
\hline SNC1P & B2 & & $\mathrm{N}$ & $\mathrm{N}$ \\
\hline SNC1P & B2.3 & $\begin{array}{l}\text { e.g., nematode and earthworm populations in soil or compost; bird populations during migration or } \\
\text { winter feeding; tadpole and mosquito larvae populations in a local pond }\end{array}$ & $\mathrm{N}$ & $\mathrm{D}$ \\
\hline SNC1P & B2.4 & & $\mathrm{N}$ & $\mathrm{N}$ \\
\hline
\end{tabular}




\begin{tabular}{|c|c|c|c|c|}
\hline SNC1P & B2.5 & & $\mathrm{N}$ & $\mathrm{N}$ \\
\hline SNC1P & B3 & & $\mathrm{N}$ & $\mathrm{N}$ \\
\hline SNC1P & B3.3 & $\begin{array}{l}\text { e.g., automobile use increases the amount of carbon dioxide in the atmosphere; planting trees reduces } \\
\text { the amount of carbon dioxide in the atmosphere }\end{array}$ & 1 & $\mathrm{~N}$ \\
\hline SNC1P & B3.5 & $\begin{array}{l}\text { e.g., the use of fertilizers and pesticides; altered shorelines; organic and conventional farming; urban } \\
\text { sprawl e.g., fertilizers change the fertility of soil, affecting what types of plants can grow in it; } \\
\text { pesticides leach into water systems, affecting water quality and aquatic life; shoreline development } \\
\text { affects the types of aquatic life and terrestrial vegetation that can live by lake shores or river banks; } \\
\text { urban sprawl wipes out fields and woods, destroying wildlife habitats }\end{array}$ & $\mathrm{D}$ & $\mathrm{N}$ \\
\hline SNC1P & C1.1 & & $\mathrm{N}$ & $\mathrm{N}$ \\
\hline SNC1P & C1.2 & & $\mathrm{N}$ & $\mathrm{N}$ \\
\hline SNC1P & E2.8 & e.g., their school, a local community centre & $\mathrm{N}$ & $\mathrm{D}$ \\
\hline CHV2O & A1.1 & $\begin{array}{l}\text { e.g., factual questions: What form of government does Canada have? What are my rights and } \\
\text { responsibilities as a citizen in my local community?; comparative questions: What are the similarities } \\
\text { and differences in the positions of stakeholder groups on an issue related to local transit in Ontario?; } \\
\text { causal questions: If I were to implement this plan of action, what impact might it have on my } \\
\text { community? }\end{array}$ & $\mathrm{N}$ & $\mathrm{D}$ \\
\hline CHV2O & A1.2 & & $\mathrm{N}$ & $N$ \\
\hline CHV2O & A1.5 & $\begin{array}{l}\text { e.g., use the concept of political significance when analysing the impact of the Canadian Charter of } \\
\text { Rights and Freedoms on Canadian society; use the concept of objectives and results when analysing } \\
\text { the intended and unintended impact of a community-planning decision; use the concept of stability } \\
\text { and change when analysing the results of an election; use the concept of political perspective when } \\
\text { evaluating the positions of different stakeholder groups on how best to foster healthy schools and } \\
\text { determining the values and beliefs that underpin these positions }\end{array}$ & $\mathrm{N}$ & 1 \\
\hline CHV2O & A1.7 & $\begin{array}{l}\text { e.g., a blog on the results of environmental action in their school; a web page on a social justice } \\
\text { issue such as child poverty and links to relevant organizations; a discussion group on how best to foster } \\
\text { healthy schools; a poster that highlights people's civic responsibilities; a news report on a plan to build } \\
\text { a big box store in the local community; a presentation on cultural celebrations of various people within } \\
\text { the local community; a protest song to commemorate or raise awareness about a violation of human } \\
\text { rights; a petition calling for clean, } \\
\text { safe water on First Nations reserves; a debate on alternative electoral processes; a work of art on the } \\
\text { value of volunteer work }\end{array}$ & $\mathrm{N}$ & $\mathrm{D}$ \\
\hline CHV2O & B1.1 & $\begin{array}{l}\text { e.g., bullying in schools; violence in local communities; accessibility of buildings in the local community } \\
\text { for people with disabilities; availability of recreational facilities in the local community; casino } \\
\text { development; voter turnout; issues related to freedom of information, taxation, water quality; } \\
\text { Aboriginal treaty rights; the impact of consumer choices; human rights issues related to racism, child } \\
\text { labour, the rights of girls or women, homophobia, or classism; intervention in foreign conflict }\end{array}$ & $\mathrm{N}$ & D \\
\hline CHV2O & B1.4 & $\begin{array}{l}\text { e.g., equitable availability of extracurricular activities in schools, a local land-use conflict, poverty or } \\
\text { violence in the local community, electoral reform, the debate over Sharia law in Ontario, the level of } \\
\text { Canada's contribution to international development assistance, food security, Aboriginal land rights }\end{array}$ & $\mathrm{D}$ & $\mathrm{D}$ \\
\hline CHV2O & B2.2 & $\begin{array}{l}\text { e.g., federal, provincial and territorial, municipal, Aboriginal governments e.g., members of } \\
\text { Parliament [MPs], senators, members of provincial Parliament [MPPs], premiers, mayors, municipal } \\
\text { councillors, chiefs, band councillors, Métis Senators }\end{array}$ & $\mathrm{D}$ & $\mathrm{N}$ \\
\hline CHV2O & C1.2 & $\begin{array}{l}\text { e.g., by serving on student council or on an organization offering support to students who are being } \\
\text { bullied; by reducing the amount of solid waste they generate and by properly disposing of hazardous } \\
\text { waste; by volunteering at a food bank, retirement home, hospital, humane society, or recreational } \\
\text { facility in the local community; by donating blood; by participating in community clean-up or tree- } \\
\text { planting days; by raising funds for a charity or a development NGO; by writing to or speaking with their } \\
\text { city or band councillor, MPP, or MP to request action on an issue }\end{array}$ & $\mathrm{N}$ & 1 \\
\hline CHV2O & C1.3 & & $\mathrm{N}$ & $\mathrm{N}$ \\
\hline CHV2O & $\mathrm{C} 2.1$ & $\begin{array}{l}\text { e.g., with reference to different racial, ethnic, and/or religious groups; people } \\
\text { with various political beliefs and/or social values; people from different age groups; men and women; } \\
\text { First Nations, Inuit, or Métis people; people in lesbian, gay, bisexual, and transgender [LGBT] } \\
\text { communities; environmentalists; people with disabilities; people from different professions and/or } \\
\text { economic circumstances; recent immigrants and new Canadians; business people }\end{array}$ & $\mathrm{N}$ & $\mathrm{D}$ \\
\hline $\mathrm{CHV} 2 \mathrm{O}$ & $\mathrm{C} 2.3$ & & $\mathrm{~N}$ & $\mathrm{~N}$ \\
\hline CHV2O & C3.2 & e.g., a public awareness campaign, a plan for local action, a campaign to pressure for political action & $\mathrm{N}$ & 1 \\
\hline GLC2O & & & $\mathrm{N}$ & $\mathrm{N}$ \\
\hline GLC2O & & & $\mathrm{N}$ & $\mathrm{N}$ \\
\hline
\end{tabular}




\begin{tabular}{|c|c|c|c|c|}
\hline SNC2D & D1.1 & $\begin{array}{l}\text { e.g., loss of habitat for Arctic mammals such as polar bears and loss of traditional lifestyles for Inuit as } \\
\text { Arctic ice shrinks; famine as arable land is lost to desertification; an increase in water-borne disease } \\
\text { and human resettlement as coastal lands are flooded; expansion of the growing season in some } \\
\text { regions }\end{array}$ & $\mathrm{D}$ & $\mathrm{N}$ \\
\hline SNC2D & D1.2 & $\begin{array}{l}\text { e.g., Drive Clean, ENERGY STAR, federal and provincial government rebates for retrofitting older } \\
\text { buildings to be more energy efficient, carbon offset programs, community tree-planting programs, } \\
\text { municipal recycling programs, Intergovernmental Panel on Climate Change [IPCC] }\end{array}$ & D & 1 \\
\hline SNC2D & D2.4 & $\begin{array}{l}\text { e.g., the combustion of fossil fuels is responsible for rising global temperatures; the concentration of } \\
\text { atmospheric } \mathrm{CO} 2 \text { is responsible for rising global temperatures; global temperatures have been on the } \\
\text { increase since the industrial revolution; the severity of cyclones, hurricanes, and tornadoes increases } \\
\text { as atmospheric temperatures increase }\end{array}$ & $\mathrm{I}$ & $\mathrm{N}$ \\
\hline SNC2D & D2.8 & & $\mathrm{N}$ & $\mathrm{N}$ \\
\hline SNC2D & D3.4 & e.g., forest fires, deforestation, the burning of fossil fuels, industrial emissions & $\mathrm{I}$ & $\mathrm{N}$ \\
\hline SNC2P & D1.2 & e.g., burning fossil fuels, implementing tree-planting programs & I & $\mathrm{N}$ \\
\hline SVN3E & B1 & & $\mathrm{N}$ & $\mathrm{N}$ \\
\hline SVN3E & B1.1 & & $\mathrm{N}$ & $\mathrm{N}$ \\
\hline SVN3E & B1.2 & & $\mathrm{N}$ & $\mathrm{N}$ \\
\hline SVN3E & B2.4 & & $\mathrm{N}$ & $\mathrm{N}$ \\
\hline SVN3E & B3 & & $\mathrm{N}$ & $\mathrm{N}$ \\
\hline SVN3E & B3.1 & $\begin{array}{l}\text { e.g., the effects of industrial or vehicle emissions on air quality; of chemical spills on soil quality; of } \\
\text { chlorination on water quality }\end{array}$ & I & $\mathrm{N}$ \\
\hline SVN3E & B3.5 & & $\mathrm{N}$ & $\mathrm{N}$ \\
\hline SVN3E & B3.6 & & $\mathrm{N}$ & $\mathrm{N}$ \\
\hline SVN3E & B2.2 & & $\mathrm{N}$ & $\mathrm{N}$ \\
\hline SVN3E & B2.3 & & $\mathrm{N}$ & $\mathrm{N}$ \\
\hline SVN3E & B2.5 & & $\mathrm{N}$ & $\mathrm{N}$ \\
\hline SVN3E & C1 & & $\mathrm{N}$ & $\mathrm{N}$ \\
\hline SVN3E & C1.2 & $\begin{array}{l}\text { e.g., mercury contamination in streams and rivers in Northern Ontario where Aboriginal people fish, } \\
\text { toxins in Arctic sea mammals hunted by Inuit, smog in large cities }\end{array}$ & 1 & $\mathrm{~N}$ \\
\hline SVN3E & $\mathrm{C} 2$ & & $\mathrm{~N}$ & $\mathrm{~N}$ \\
\hline SVN3E & $\mathrm{C} 2.2$ & e.g., smog, ultraviolet [UV] rays, bacteria, pesticide residue & I & $\mathrm{N}$ \\
\hline SVN3E & $\mathrm{C} 3$ & & $\mathrm{~N}$ & $\mathrm{~N}$ \\
\hline SVN3E & C3.1 & $\begin{array}{l}\text { e.g., air, noise, soil, and water pollution; UV rays; heat; heavy metals; work- place chemicals; } \\
\text { pathogens }\end{array}$ & $\mathrm{I}$ & $N$ \\
\hline SVN3E & D1.1 & $\begin{array}{l}\text { e.g., local, provincial, or national initiatives by government, business, or non-governmental } \\
\text { organizations }\end{array}$ & $\mathrm{N}$ & 1 \\
\hline SVN3E & D3.3 & & $\mathrm{N}$ & $\mathrm{N}$ \\
\hline SVN3E & E2.3 & $\begin{array}{l}\text { e.g., making plant tallies in forests; tagging or marking ground vegetation species in fields; tagging and } \\
\text { tracking wildlife with the global positioning system in remote areas; using aquatic dip nets for sampling } \\
\text { organisms in shallow ponds or streams }\end{array}$ & $\mathrm{N}$ & $\mathrm{D}$ \\
\hline SVN3E & E2.4 & e.g., a field, a pond & $\mathrm{N}$ & $\mathrm{D}$ \\
\hline
\end{tabular}

\begin{tabular}{|c|c|c|c|c|c|c|c|}
\hline $\begin{array}{l}\text { COURSE } \\
\text { CODE }\end{array}$ & 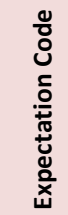 & SAMPLE QUESTIONS & $\begin{array}{c}\text { Urban EE } \\
\text { (Direct } \\
\text { /Indirect } \\
\text { / None) }\end{array}$ & $\begin{array}{l}\text { Place- } \\
\text { Based EE } \\
\text { (Direct / } \\
\text { Indirect / } \\
\text { None) }\end{array}$ & $\begin{array}{l}\text { U/PB EE } \\
\text { THEME(S) }\end{array}$ & 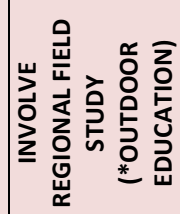 & 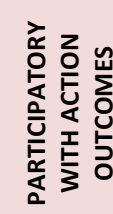 \\
\hline CGC1D & $\begin{array}{l}\mathrm{A} 1.1 \\
\end{array}$ & & $N$ & $\mathrm{~N}$ & $\begin{array}{l}\text { Systems } \\
\text { (Transportation) }\end{array}$ & No & No \\
\hline
\end{tabular}




\begin{tabular}{|c|c|c|c|c|c|c|c|}
\hline CGC1D & A1.5 & $\begin{array}{l}\text { Sample questions: "How does the concept of } \\
\text { spatial significance support our understanding of a } \\
\text { place's distinctive characteristics?" "What criteria } \\
\text { could be used to determine if the characteristics } \\
\text { of a place form a pattern?" "Which concept or } \\
\text { concepts of geographic thinking could be used to } \\
\text { evaluate how a change in the natural environment } \\
\text { will affect people?" “How can using the concept of } \\
\text { geographic perspective improve our } \\
\text { understanding of a complex issue?" }\end{array}$ & $\mathrm{N}$ & $\mathrm{N}$ & Planning & No & No \\
\hline CGC1D & A1.6 & $\begin{array}{l}\text { Sample questions: "What geographic criteria could } \\
\text { be used when considering possible changes to } \\
\text { Canadian immigration policy?" "Does the financial } \\
\text { benefit of extracting natural resources justify } \\
\text { related social and/or environ- mental impacts?" }\end{array}$ & 1 & None & $\begin{array}{l}\text { Immigration and } \\
\text { Settlement }\end{array}$ & No & No \\
\hline CGC1D & A2.3 & $\begin{array}{l}\text { Sample questions: "How does the Canadian } \\
\text { government use issues related to the spatial } \\
\text { significance of global oil reserves to promote the } \\
\text { Alberta oil sands? How might you use geographic } \\
\text { perspective to assess the strength of the } \\
\text { government's arguments?" "What kinds of } \\
\text { patterns and trends might you want to consider if } \\
\text { you were analysing a news story about climate } \\
\text { change?" "What is the relationship between the } \\
\text { availability of inexpensive products in Canada and } \\
\text { labour or environmental standards in developing } \\
\text { countries?" "What concepts of geographic } \\
\text { thinking might help you assess the strengths and } \\
\text { weaknesses of arguments supporting different } \\
\text { approaches to the expansion of public transit?" }\end{array}$ & $\mathrm{D}$ & $\mathrm{N}$ & $\begin{array}{l}\text { Systems } \\
\text { (Transportation) }\end{array}$ & No & No \\
\hline CGC1D & B1.2 & $\begin{array}{l}\text { Sample questions: "How do the physical } \\
\text { characteristics of different regions influence } \\
\text { tourism in Canada?" "How would a graph showing } \\
\text { seismic activity help planners make decisions } \\
\text { relating to urban settlement?" "How would you } \\
\text { use GIS to determine the best place to locate a } \\
\text { wind farm?" "How do soil, climate, and landscape } \\
\text { influence agricultural practices (e.g., contour } \\
\text { ploughing, ranching, intensive agriculture)?" "How } \\
\text { will the effect of warmer temperatures on caribou } \\
\text { migration affect Inuit and other Aboriginal } \\
\text { communities in Canada's North?" }\end{array}$ & $\mathrm{D}$ & $\mathrm{N}$ & Planning & No & No \\
\hline CGC1D & B1.3 & $\begin{array}{l}\text { Sample questions: "How might a warmer climate } \\
\text { affect the skiing industry or the maple syrup } \\
\text { industry in southern Ontario or grain farming on } \\
\text { the Prairies?" "How do environ- mental changes } \\
\text { affect plants and animals? What are some plants } \\
\text { and animals that are now at risk or may become } \\
\text { so because of environmental changes?" "How } \\
\text { does a change in permafrost affect transportation } \\
\text { and infrastructure?" "What influence might } \\
\text { warmer temperatures and more frequent severe } \\
\text { storms have on high-density urban centres in } \\
\text { Canada?" "How can communities respond to } \\
\text { shoreline erosion?" }\end{array}$ & $\mathrm{D}$ & $\mathrm{N}$ & Climate & No & No \\
\hline CGC1D & B1.4 & $\begin{array}{l}\text { Sample question: "What impact do exhaust } \\
\text { emissions from vehicles have on our climate? } \\
\text { Why?" }\end{array}$ & I & $\mathrm{N}$ & Ecological & No & No \\
\hline CGC1D & B3.2 & $\begin{array}{l}\text { Sample questions: "How have climatic processes } \\
\text { influenced the physical features of the area in } \\
\text { which you live? What evidence illustrates that } \\
\text { climatic processes are continuing to affect the } \\
\text { landscape?" “How do the climatic characteristics } \\
\text { of Canada's prairie region influence the types of } \\
\text { vegetation within the region?" "How do the rock } \\
\text { types in different regions of Canada affect the } \\
\text { topography of the Canadian landscape?" “How did } \\
\text { glaciation affect drainage, soil quality, and } \\
\text { vegetation in the Canadian Shield as compared to } \\
\text { in the Great Lakes-St. Lawrence Lowlands and/or } \\
\text { the Hudson Bay Lowlands? }\end{array}$ & $\mathrm{N}$ & $\mathrm{D}$ & Climate & No & No \\
\hline CGC1D & C1.1 & $\begin{array}{l}\text { Sample questions: "How effective are the waste } \\
\text { management practices in your community in } \\
\text { supporting sustainability? What happens to } \\
\text { material that is recycled in your community? } \\
\text { Is the recycling program reducing the amount of } \\
\text { waste people produce?" "How have various mine } \\
\text { sites (open pit, quarry, and/or shaft mines) been } \\
\text { rehabilitated?" "How have cod stocks responded } \\
\text { since the federal government closed the cod } \\
\text { fishery in } 1992 \text { ? What problems continue to } \\
\text { prevent the recovery of the cod population?" }\end{array}$ & $\mathrm{N}$ & $\mathrm{D}$ & Systems (Waste) & No & No \\
\hline
\end{tabular}




\begin{tabular}{|c|c|c|c|c|c|c|c|}
\hline CGC1D & $\mathrm{C} 2.4$ & $\begin{array}{l}\text { Sample questions: "What would the costs and } \\
\text { benefits of developing a wind and/or solar farm be } \\
\text { for your community, a community in southern } \\
\text { Alberta, or another location of your choice?" "In } \\
\text { what areas of Canada might it be feasible to use } \\
\text { tides as an energy source?" }\end{array}$ & $\mathrm{N}$ & I & Systems (Energy) & No & No \\
\hline CGC1D & C3.4 & $\begin{array}{l}\text { Sample questions: "How might the key location } \\
\text { factors differ for different kinds of farming (e.g., } \\
\text { corn, dairy, fruit)?" "What industrial location } \\
\text { factors make Sault Ste. Marie an attractive site for } \\
\text { alternative energy development?" "What, in order } \\
\text { of importance, are the most significant location } \\
\text { factors for an entertainment business?" }\end{array}$ & $\mathrm{N}$ & $\mathrm{N}$ & Planning & No & No \\
\hline CGC1D & D1.1 & $\begin{array}{l}\text { Sample questions: "Are most communities in } \\
\text { Canada being affected by the same major } \\
\text { population trends, or do the trends and impacts } \\
\text { vary from one community to another?" “As the } \\
\text { number of elderly people increases, what changes } \\
\text { will communities have to make to their infra- } \\
\text { structure?" "Will today's major population trends } \\
\text { remain important in the future? Why or why not? }\end{array}$ & $\mathrm{D}$ & 1 & $\begin{array}{l}\text { Sociogeographic, } \\
\text { Planning, Systems }\end{array}$ & No & No \\
\hline CGC1D & $\mathrm{D} 2.1$ & $\begin{array}{l}\text { Sample questions: "Why do immigrants settle in a } \\
\text { particular location?" "Should governments } \\
\text { attempt to control where immigrants settle in } \\
\text { Canada?" "Why are workers from other countries } \\
\text { sometimes brought into Canada on a temporary } \\
\text { basis instead of being allowed to enter as } \\
\text { immigrants?" "What types of incentives might } \\
\text { companies and/or governments offer to } \\
\text { encourage people to settle in a particular } \\
\text { location?" }\end{array}$ & 1 & $\mathrm{~N}$ & $\begin{array}{l}\text { Immigration and } \\
\text { Settlement }\end{array}$ & No & No \\
\hline CGC1D & D2.2 & $\begin{array}{l}\text { Sample questions: "What support may newcomers } \\
\text { need to settle comfortably into a community (e.g., } \\
\text { assistance with jobs and housing, language } \\
\text { training)?" "What are the advantages and } \\
\text { disadvantages of providing supports for immigrant } \\
\text { groups within a community?" }\end{array}$ & $\mathrm{D}$ & $\mathrm{N}$ & $\begin{array}{l}\text { Immigration and } \\
\text { Settlement }\end{array}$ & No & No \\
\hline CGC1D & D2.3 & $\begin{array}{l}\text { Sample questions: "What are the costs and } \\
\text { benefits, for refugees and for Canada, of admitting } \\
\text { refugees?" "What criteria should } \\
\text { be considered to determine the number of } \\
\text { refugees Canada accepts?" "How do you think } \\
\text { Canada's immigration needs and refugee } \\
\text { obligations may change in the future, and how } \\
\text { might those changes affect the categories under } \\
\text { which immigrants are admitted?" "In what ways } \\
\text { can a community's ethnic and cultural } \\
\text { composition influence the way it looks and the } \\
\text { way it functions?" }\end{array}$ & $\mathrm{D}$ & I & $\begin{array}{l}\text { Immigration and } \\
\text { Settlement }\end{array}$ & No & No \\
\hline CGC1D & D3.2 & $\begin{array}{l}\text { Sample questions: "Why do people live where } \\
\text { they do? What would you do to attract people to a } \\
\text { particular location?" “How can an industry } \\
\text { influence the demographics of a community?" }\end{array}$ & 1 & 1 & $\begin{array}{l}\text { Immigration and } \\
\text { Settlement, } \\
\text { Systems, Planning }\end{array}$ & No & No \\
\hline CGC1D & D3.3 & $\begin{array}{l}\text { Sample questions: "How do the demographic } \\
\text { characteristics of your community compare with } \\
\text { more general national characteristics?" "How is } \\
\text { the percentage of working-age people (20-65) in } \\
\text { the total population changing? What are the } \\
\text { implications of this change?" "What is the age } \\
\text { distribution in your community, and how does it } \\
\text { affect your community now?" }\end{array}$ & $\mathrm{N}$ & $\mathrm{D}$ & Sociogeographic & No & No \\
\hline CGC1D & D3.4 & $\begin{array}{l}\text { Sample questions: "Choose two communities } \\
\text { other than your own, one with a large population } \\
\text { and one with a small population. How do the } \\
\text { population characteristics of your community } \\
\text { compare with the population characteristics of } \\
\text { these communities?" "How do the population } \\
\text { characteristics of the three largest cities in Canada } \\
\text { compare with each other?" "How do Canada's } \\
\text { general population characteristics compare with } \\
\text { those of other countries around the world? }\end{array}$ & $\mathrm{D}$ & $\mathrm{D}$ & $\begin{array}{l}\text { Immigration and } \\
\text { Settlement, } \\
\text { Sociogeographic }\end{array}$ & No & No \\
\hline CGC1D & D3.5 & $\begin{array}{l}\text { Sample questions: "Why would people choose to } \\
\text { leave a rural life and move to an urban } \\
\text { settlement? Why would people choose to move to } \\
\text { another province or territory? What are the } \\
\text { impacts of these trends on society?" }\end{array}$ & $\mathrm{D}$ & $\mathrm{N}$ & $\begin{array}{l}\text { Immigration and } \\
\text { Settlement }\end{array}$ & No & No \\
\hline
\end{tabular}




\begin{tabular}{|c|c|c|c|c|c|c|c|}
\hline CGC1D & D3.1 & $\begin{array}{l}\text { Sample questions: “Where do people live in } \\
\text { Canada and why?" "What pattern or patterns do } \\
\text { you see in the location of First Nations reserves } \\
\text { across Canada? What are some factors that } \\
\text { account for the location of reserves?" "What are } \\
\text { some physical factors that may influence the } \\
\text { location of a settlement?" "How might access to } \\
\text { various forms of transportation influence the } \\
\text { development and density of com- munities? How } \\
\text { would a settlement pattern influenced by highway } \\
\text { routes differ from one influenced by flight } \\
\text { routes?" “What's the differencee between a town, } \\
\text { a city, and a census metropolitan area (CMA)? } \\
\text { Why might a city prefer to be called a town?" } \\
\text { "Why do some settlements grow into large } \\
\text { metropolitan areas and others stay as small } \\
\text { towns?" }\end{array}$ & D & $\mathrm{N}$ & $\begin{array}{l}\text { Immigration and } \\
\text { Settlement, Urban } \\
\text { Systems, Planning }\end{array}$ & No & No \\
\hline CGC1D & E2.2 & $\begin{array}{l}\text { Sample questions: "In what ways might urban } \\
\text { growth influence the type of policing in a com- } \\
\text { munity?" "What types of health care services } \\
\text { might be needed in a large urban community? } \\
\text { Why might they be different from those needed in } \\
\text { a small town?" "How might the increased } \\
\text { migration of First Nations people from reserves to } \\
\text { urban centres have an impact on both } \\
\text { communities?" }\end{array}$ & D & $\mathrm{N}$ & $\begin{array}{l}\text { Sociogeographic, } \\
\text { Ecological, } \\
\text { Systems, Planning }\end{array}$ & No & No \\
\hline $\begin{array}{ll}\text { CGC1D } \\
\end{array}$ & E1.2 & $\begin{array}{l}\text { Sample questions: "What are the costs and } \\
\text { benefits of air travel? How do carbon offset } \\
\text { programs mitigate the environmental impact of air } \\
\text { travel? Are they enough?" "How can changes in } \\
\text { transportation systems help to control urban } \\
\text { sprawl?" "Why might some communities consider } \\
\text { creating a bike lane as an alternative to widening a } \\
\text { roadway? Why might this option be better in } \\
\text { some communities than others?" }\end{array}$ & $\mathrm{D}$ & $\mathrm{N}$ & $\begin{array}{l}\text { Systems } \\
\text { (Transportation) }\end{array}$ & No & No \\
\hline CGC1D & E2.1 & $\begin{array}{l}\text { Sample questions: "How might the draining of } \\
\text { marshland for urban development affect drainage } \\
\text { patterns, the microclimate, and//or wildlife?" } \\
\text { "What impact might an increase in population } \\
\text { density have on sewage treatment processes and } \\
\text { on nearby bodies of water?" "What effects have } \\
\text { increases in the amount of paved land had on } \\
\text { groundwater? How have water bodies been } \\
\text { affected by increased runoff from paved areas, } \\
\text { and how might communities that use that water } \\
\text { be affected?" "How do paved areas affect air } \\
\text { temperature?" }\end{array}$ & $\mathrm{D}$ & $\mathrm{N}$ & $\begin{array}{l}\text { Systems, } \\
\text { Ecological, Climate }\end{array}$ & No & No \\
\hline CGC1D & E2 & & $\mathrm{N}$ & $\mathrm{N}$ & Systems, Planning & No & No \\
\hline CGC1D & E3.1 & $\begin{array}{l}\text { Sample questions: "What services does a city's } \\
\text { central business district or downtown provide? } \\
\text { Why is a thriving central business district } \\
\text { important to a city?" “How do the commercial } \\
\text { land uses within a community help to unite the } \\
\text { community or divide it?" "What benefits do } \\
\text { recreational spaces and facilities provide for this } \\
\text { community? Are all age groups supported by the } \\
\text { recreational spaces available?" "Do all } \\
\text { neighbourhoods have equal access to parks and } \\
\text { green space?" “Why is industrial land often } \\
\text { located on the perimeter of the city?" "Why might } \\
\text { the location of a specific kind of land use within a } \\
\text { community change over time?" "How do } \\
\text { municipal taxes both influence and reflect the } \\
\text { characteristics of land use in the community?" }\end{array}$ & $\mathrm{D}$ & 1 & Planning, Systems & No & No \\
\hline $\begin{array}{ll}\text { CGC1D } \\
\end{array}$ & E1.1 & $\begin{array}{l}\text { Sample questions: "Do present food production } \\
\text { practices support the sustainability of the food } \\
\text { system?" "Why would it be important to have } \\
\text { dairy farming close to urban centres?" "What role } \\
\text { does the availability of local food play in making } \\
\text { communities more sustainable?" "What options } \\
\text { are available to consumers if they wish to make } \\
\text { more sustainable food choices?" }\end{array}$ & D & $\mathrm{N}$ & Systems (Food) & No & No \\
\hline CGC1D & E1.4 & $\begin{array}{l}\text { Sample questions: "What is the multiplier effect? } \\
\text { How does the establishment or loss of a major } \\
\text { industry affect other businesses in a community?" } \\
\text { "How have towns that have lost their major } \\
\text { industry been able to survive (e.g., Stratford, Elliot } \\
\text { Lake)? Why have some other communities } \\
\text { become ghost towns?" "What kinds of public } \\
\text { services and infrastructure does a community } \\
\text { need to remain socially stable and economically } \\
\text { viable?" "What role do taxes have in sustaining a }\end{array}$ & 1 & 1 & Systems, Planning & No & No \\
\hline
\end{tabular}




\begin{tabular}{|c|c|c|c|c|c|c|c|}
\hline & & $\begin{array}{l}\text { community?" "What are the economic and social } \\
\text { characteristics of a diverse neighbourhood, and } \\
\text { how do they support sustainability?" }\end{array}$ & & & & & \\
\hline CGC1D & E1.5 & $\begin{array}{l}\text { Sample questions: "What criteria could be used to } \\
\text { evaluate a community's progress in achieving } \\
\text { environmental sustainability? What economic } \\
\text { criteria would a plan to improve environmental } \\
\text { sustainability have to meet in order to be practical } \\
\text { to adopt and viable in the long term?" "Does your } \\
\text { course of action support the cultural needs of the } \\
\text { people living in the community? }\end{array}$ & $\mathrm{N}$ & 1 & Sustainability & No & No \\
\hline CGC1D & E2.3 & $\begin{array}{l}\text { Sample questions: "How does the official plan for } \\
\text { your community address urban sprawl?" "Should } \\
\text { there be maximum size limits for cities?" "Should } \\
\text { there be restrictions on the use of farmland for } \\
\text { development or on other land uses near urban } \\
\text { centres?" }\end{array}$ & $\mathrm{D}$ & $\mathrm{D}$ & Planning & No & No \\
\hline CGC1D & E3.2 & $\begin{array}{l}\text { Sample questions: "How has the physical site of a } \\
\text { community influenced land use within it?" "Are } \\
\text { there any physical features within the community } \\
\text { that might have been built (e.g., hills, lakes, } \\
\text { waterfront land)? If so, why were they built?" }\end{array}$ & $\mathrm{D}$ & 1 & Planning & No & No \\
\hline CGC1D & E3.3 & $\begin{array}{l}\text { Sample questions: "Which type of land use takes } \\
\text { up the most space in the community?" "Where is } \\
\text { most of the commercial space?" "What reasons } \\
\text { support having that type of land use in that } \\
\text { particular location and not somewhere else?" }\end{array}$ & $\mathrm{D}$ & $\mathrm{I}$ & Planning & No & No \\
\hline CGC1P & A1.1 & & $\mathrm{N}$ & $\mathrm{N}$ & $\begin{array}{l}\text { Systems } \\
\text { (Transportation), } \\
\text { Ecological }\end{array}$ & No & No \\
\hline CGC1P & A1.2 & $\begin{array}{l}\text { Sample questions: "How might you use statistics } \\
\text { relating to temperature and precipitation for a } \\
\text { specific location? Where might you find these } \\
\text { data? }\end{array}$ & $\mathrm{N}$ & 1 & Climate & No & No \\
\hline CGC1P & A1.4 & $\begin{array}{l}\text { Sample questions: "What kinds of tools, including } \\
\text { organizers, can you use to analyse data and } \\
\text { information? How are they helpful?" "What } \\
\text { graphic organizer could you use to compare data } \\
\text { and information on different communities in order } \\
\text { to make a decision on where to live?" }\end{array}$ & $\mathrm{N}$ & $\mathrm{I}$ & $\begin{array}{l}\text { Planning, } \\
\text { Ecological, } \\
\text { Sociogeographic }\end{array}$ & No & No \\
\hline CGC1P & A.15 & $\begin{array}{l}\text { Sample questions: "What would be the } \\
\text { advantages and disadvantages of building high- } \\
\text { rise apartments in a particular place?" “What } \\
\text { trends do you see in the use of alternative energy } \\
\text { in Ontario?" "How might consumer choices relate } \\
\text { to social justice and environmental } \\
\text { sustainability?" "What is the relationship between } \\
\text { a particular resource and the economy?" “How } \\
\text { will warmer winter temperatures affect } \\
\text { businesses that rely on cooler temperatures (e.g., } \\
\text { skiing resorts, wineries that make ice wine)?” } \\
\text { "When considering an issue, how does using } \\
\text { geographic perspective enable you to analyse its } \\
\text { complexity?" }\end{array}$ & $\mathrm{D}$ & $\mathrm{N}$ & Planning & No & No \\
\hline CGC1P & A1.6 & $\begin{array}{l}\text { Sample questions: "What criteria could be used to } \\
\text { choose the best place to live in Canada?" "Given } \\
\text { your community's current population trends, what } \\
\text { will its land-use needs will be in the near future?" }\end{array}$ & $\mathrm{N}$ & $\mathrm{D}$ & Planning & No & No \\
\hline CGC1P & A2.3 & $\begin{array}{l}\text { Sample questions: "Why would understanding the } \\
\text { spatial significance of the global distribution of } \\
\text { fresh water help you analyse a controversy over } \\
\text { foreign access to Canada's fresh water?" "What } \\
\text { kinds of patterns and trends might you want to } \\
\text { consider if you were discussing a news story about } \\
\text { climate change?" "What is the interrelationship } \\
\text { between resource use, the environment, and } \\
\text { current debates about expanding public transit? } \\
\text { How does this issue affect you or your personal } \\
\text { choices?" "How will an analysis based on } \\
\text { geographic perspective help you achieve a more } \\
\text { balanced understanding of a controversial issue, } \\
\text { such as a proposal to build a large industrial } \\
\text { facility near a residential area?" }\end{array}$ & $\mathrm{D}$ & $\mathrm{N}$ & Planning & No & No \\
\hline
\end{tabular}




\begin{tabular}{|c|c|c|c|c|c|c|c|}
\hline CGC1P & B1.4 & $\begin{array}{l}\text { Sample questions: "How do human activities } \\
\text { contribute to changes in Canada's climate?" } \\
\text { "What are some of the environmental costs } \\
\text { that may occur when humans adapt the natural } \\
\text { landscape to their needs (e.g., by building } \\
\text { irrigation systems, clearing land, draining } \\
\text { marshes)?" "Consider a proposal for adapting a } \\
\text { natural feature in your area for human use (e.g., } \\
\text { filling in a swamp and building a shopping mall on } \\
\text { it). What are the environmental, economic, social, } \\
\text { and political implications of the proposal? How } \\
\text { would the costs and benefits of this proposal } \\
\text { compare with those of leaving the natural feature } \\
\text { untouched or modifying it in a way that preserved } \\
\text { most of its natural characteristics but allowed } \\
\text { some human use?" }\end{array}$ & 1 & $\mathrm{D}$ & $\begin{array}{l}\text { Ecological, } \\
\text { Planning }\end{array}$ & No & No \\
\hline CGC1P & B2.2 & $\begin{array}{l}\text { Sample questions: "What does a population } \\
\text { settlement map tell us about the preferred range } \\
\text { of latitude for settlement in Canada?" "Where will } \\
\text { people resettle if coastal areas are flooded?" } \\
\text { "How have people adapted to areas where natural } \\
\text { characteristics are not conducive to settlement?" }\end{array}$ & $\mathrm{D}$ & $\mathrm{N}$ & Sociogeographic & No & No \\
\hline CGC1P & B3.1 & $\begin{array}{l}\text { Sample questions: "What would you consider to } \\
\text { be the three most important natural features in } \\
\text { your community? What makes them important to } \\
\text { the community? Should the community ensure } \\
\text { that they are preserved?" }\end{array}$ & $\mathrm{N}$ & $\mathrm{D}$ & Ecological & No & No \\
\hline CGC1P & B3.2 & $\begin{array}{l}\text { Sample questions: "Which community would be } \\
\text { the hardest to adjust to if you were to move to it? } \\
\text { Why?" "Which communities are in the best food- } \\
\text { growing areas?" "Which of the communities you } \\
\text { have looked at has the landscape and climate } \\
\text { conditions best suited to your favourite outdoor } \\
\text { activities?" }\end{array}$ & $\mathrm{N}$ & $\mathrm{N}$ & Ecological & No & No \\
\hline CGC1P & C1.1 & $\begin{array}{l}\text { Sample questions: "Where in Canada would wind } \\
\text { energy be a good option for a community?" "How } \\
\text { are individuals, businesses, and communities in } \\
\text { Canada using solar energy?" "Which alternative } \\
\text { energy option(s) would be best for your } \\
\text { community or local area?" }\end{array}$ & $\mathrm{N}$ & $\mathrm{D}$ & Systems (Energy) & No & No \\
\hline CGC1P & $\mathrm{C} 2.3$ & $\begin{array}{l}\text { Sample questions: "What are the social, economic, } \\
\text { and environmental costs and benefits of having } \\
\text { this industry in the area?" "How would other } \\
\text { businesses in our area be affected if this industry } \\
\text { were to collapse? How might this affect you?" } \\
\text { "How would a new sports attraction (e.g., a } \\
\text { hockey team, a major sporting event) affect a } \\
\text { community? What other businesses might it } \\
\text { attract?" "How might the development of the rich } \\
\text { mineral resources of northern Ontario's ring of } \\
\text { fire region affect First Nations communities in } \\
\text { the area?" }\end{array}$ & $\mathrm{N}$ & $\mathrm{D}$ & Planning & No & No \\
\hline CGC1P & D1.1 & $\begin{array}{l}\text { Sample questions: "How will people's needs } \\
\text { change as they get older?" "How will an aging } \\
\text { population affect the types of goods and services } \\
\text { available in their community?" "What do } \\
\text { immigrants need to establish themselves in a new } \\
\text { country?" "How are Canadian families changing?" }\end{array}$ & 1 & $\mathrm{~N}$ & $\begin{array}{l}\text { Sociogeographic, } \\
\text { Immigration and } \\
\text { Settlement }\end{array}$ & No & No \\
\hline CGC1P & D1.2 & $\begin{array}{l}\text { Sample questions: "In what ways can cultural } \\
\text { diversity enrich the life of a community?" "Why } \\
\text { might tensions develop between people from } \\
\text { different ethnic backgrounds? What strategies } \\
\text { might prevent or reduce these tensions?" }\end{array}$ & 1 & $\mathrm{~N}$ & $\begin{array}{l}\text { Immigration and } \\
\text { Settlement }\end{array}$ & No & No \\
\hline CGC1P & $\begin{array}{l}\mathrm{D} 1.3 \\
\end{array}$ & $\begin{array}{l}\text { Sample questions: "Is it better to invest in more } \\
\text { nursing homes for the elderly or more home-care } \\
\text { support?" "What kinds of support services are } \\
\text { available for immigrants? Who provides them?" } \\
\text { "How can schools help newcomers?" "What can } \\
\text { employers do to help single parents balance work } \\
\text { and childcare responsibilities?" }\end{array}$ & 1 & $\mathrm{~N}$ & $\begin{array}{l}\text { Sociogeographic, } \\
\text { Immigration and } \\
\text { Settlement }\end{array}$ & No & No \\
\hline CGC1P & D1.4 & $\begin{array}{l}\text { Sample questions: "Are the population trends in } \\
\text { your community similar to the trends in Canada as } \\
\text { a whole?" "What do you anticipate will be the } \\
\text { biggest area of concern in your community as a } \\
\text { result of these trends?" "What kinds of business } \\
\text { opportunities do you see emerging as a result of } \\
\text { the changes taking place in the population of your } \\
\text { community?" }\end{array}$ & $\mathrm{N}$ & $\mathrm{D}$ & Sociogeographic & No & No \\
\hline CGC1P & $\mathrm{D} 2.1$ & $\begin{array}{l}\text { Sample questions: "What are the different } \\
\text { categories in which immigrants can apply for entry } \\
\text { into Canada? What factors affect the number of } \\
\text { people applying in each category? Which category } \\
\text { do you think most future immigrants will apply for } \\
\text { and why?" }\end{array}$ & 1 & $\mathrm{~N}$ & $\begin{array}{l}\text { Immigration and } \\
\text { Settlement }\end{array}$ & No & No \\
\hline CGC1P & D3.1 & $\begin{array}{l}\text { Sample questions: "What are the advantages and } \\
\text { disadvantages of living in a suburb of a large city? } \\
\text { Which would you prefer to live in, the suburb or }\end{array}$ & $\mathrm{D}$ & $\mathrm{N}$ & $\begin{array}{l}\text { Immigration and } \\
\text { Settlement, } \\
\text { Sociogeographic }\end{array}$ & No & No \\
\hline
\end{tabular}




\begin{tabular}{|c|c|c|c|c|c|c|c|}
\hline & & $\begin{array}{l}\text { the city?" "Why might a First Nation student } \\
\text { prefer to live on a reserve rather than in a nearby } \\
\text { city?" "Is there a pattern to where people live in } \\
\text { Canada?" "What role does the Trans-Canada } \\
\text { Highway play in the distribution of population } \\
\text { settlement in Canada?" }\end{array}$ & & & & & \\
\hline CGC1P & D3.2 & $\begin{array}{l}\text { Sample questions: "What three languages are } \\
\text { most commonly spoken in Canada?" "How does } \\
\text { the number of people under } 25 \text { compare to the } \\
\text { number of people over } 65 \text { ? Why is this important } \\
\text { to know?" "How do the population density and } \\
\text { other population characteristics of your } \\
\text { community or local area compare with those of } \\
\text { other Canadian communities?" }\end{array}$ & $\mathrm{D}$ & $\mathrm{D}$ & Sociogeographic & No & No \\
\hline CGC1P & E1.2 & $\begin{array}{l}\text { Sample questions: "Can all waste materials be } \\
\text { disposed of in the same manner? Why or why } \\
\text { not?" "How does your community dispose of } \\
\text { unwanted electronics?" "What happens to your } \\
\text { garbage if your community does not have a landfill } \\
\text { site?" “What could communities and individuals } \\
\text { do to minimize the amount of material that has to } \\
\text { be landfilled or incinerated?" }\end{array}$ & $\mathrm{N}$ & $\mathrm{D}$ & Systems (Waste) & No & No \\
\hline CGC1P & E1.4 & $\begin{array}{l}\text { Sample questions: "What can you do to make a } \\
\text { difference in your community?" "How does the } \\
\text { community benefit if you take your own bag when } \\
\text { you shop for groceries?" "How does eating local } \\
\text { foods, cleaning up a local river, installing a green } \\
\text { roof on the school, or using alternative energy } \\
\text { support sustainability?" "How might the } \\
\text { community benefit economic- ally, socially, and } \\
\text { environmentally from the preservation or } \\
\text { restoration of a heritage building?" "What } \\
\text { changes can you make to your home that would } \\
\text { help make the community more environmentally } \\
\text { sustainable?" }\end{array}$ & $\mathrm{N}$ & $\mathrm{D}$ & Sustainability & No & No \\
\hline CGC1P & E2.2 & $\begin{array}{l}\text { Sample questions: "Are recreational areas close to } \\
\text { the residential areas?" "Do public transportation } \\
\text { routes provide easy access to commercial areas?" } \\
\text { "Is residential land located near industrial } \\
\text { spaces?" "Are sewage treatment plants next to } \\
\text { recreational land?" "If you were to redesign your } \\
\text { community, would you change the patterns of } \\
\text { land use in any way?" }\end{array}$ & $\mathrm{D}$ & $\mathrm{D}$ & Planning & No & No \\
\hline CGC1P & E2.3 & $\begin{array}{l}\text { Sample questions: "How might the closure of a } \\
\text { pulp and paper mill lead to the decline of a } \\
\text { community?" "Why would people choose to move } \\
\text { to the suburbs? Why is the resulting urban sprawl } \\
\text { a problem?" "Why is it beneficial to have housing } \\
\text { near a downtown commercial area?" "What types } \\
\text { of social issues may arise from changes in land use } \\
\text { in an urban community?" }\end{array}$ & $\mathrm{D}$ & $\mathrm{N}$ & Planning & No & No \\
\hline CGC1P & E2.4 & $\begin{array}{l}\text { Sample questions: "If you were planning on } \\
\text { moving to a new community, why would it be } \\
\text { important for you to check on future plans for the } \\
\text { community?" "Why might it be worthwhile to } \\
\text { attend a planning meeting about a proposed } \\
\text { project in your community? What could you do to } \\
\text { voice your ideas?" }\end{array}$ & $\mathrm{N}$ & $\mathrm{D}$ & Planning & No & No \\
\hline CGC1P & E3 & & $\mathrm{N}$ & $\mathrm{N}$ & Planning & No & No \\
\hline CGC1P & E3.1 & $\begin{array}{l}\text { Sample questions: "How can aerial photographs of } \\
\text { the community help us identify different land } \\
\text { uses? How could you use the photographs to see } \\
\text { changes in land use and plan for future land-use } \\
\text { needs?" }\end{array}$ & $\mathrm{D}$ & $\mathrm{D}$ & Planning & No & No \\
\hline CGC1P & E3.2 & & $\mathrm{N}$ & $\mathrm{N}$ & Planning, Systems & No & No \\
\hline CGC1P & E3.3 & & $\mathrm{N}$ & $\mathrm{N}$ & Planning, Systems & No & No \\
\hline SNC1D & B1 & & $\mathrm{N}$ & $\mathrm{N}$ & Ecological & No & No \\
\hline SNC1D & B1.1 & $\begin{array}{l}\text { Sample issue: The Great Lakes constitute an } \\
\text { important shipping route. Foreign ships often } \\
\text { empty their ballast water, which can contain } \\
\text { invasive species, directly into the lakes. The goby, } \\
\text { which was likely imported in ballast water, is an } \\
\text { aggressive fish that has taken over the spawning } \\
\text { grounds of some native species, threatening the } \\
\text { balance of the ecosystem. } \\
\text { Sample questions: How has suburban } \\
\text { development on the Niagara Escarpment or the } \\
\text { Oak Ridges Moraine affected local ecosystems? } \\
\text { How has the zebra mussel population in Lake Erie } \\
\text { affected aquatic species and water quality? How } \\
\text { has commercial logging affected the sustainability } \\
\text { of forests in Northern Ontario? }\end{array}$ & $\mathrm{D}$ & $\mathrm{N}$ & Ecological & No & No \\
\hline
\end{tabular}




\begin{tabular}{|c|c|c|c|c|c|c|c|}
\hline SNC1D & B1.2 & $\begin{array}{l}\text { Sample issue: Landfill sites can have negative } \\
\text { effects on adjacent ecosystems, attracting pests, } \\
\text { leaching toxic chemicals, and producing } \\
\text { greenhouse gases. Municipal recycling and } \\
\text { composting programs divert garbage, reducing the } \\
\text { need for new land- fill sites. However, many } \\
\text { people, particularly rural residents and those in } \\
\text { apartment buildings, may not be included in these } \\
\text { programs. } \\
\text { Sample questions: What provincial or federal } \\
\text { legislation attempts to protect special features or } \\
\text { sensitive elements of terrestrial or freshwater } \\
\text { ecosystems? How could such legislation be more } \\
\text { effective? How have the actions of local wetland- } \\
\text { reclamation, municipal tree-planting, Aboriginal } \\
\text { fisheries-management, Great Lakes- } \\
\text { rehabilitation, organic farming, or other groups } \\
\text { helped to ensure ecological sustainability? What } \\
\text { further action could such groups take? }\end{array}$ & D & $\mathrm{N}$ & $\begin{array}{l}\text { Politics, Ecological, } \\
\text { Planning }\end{array}$ & No & No \\
\hline SNC1D & B2 & & $\mathrm{N}$ & $\mathrm{N}$ & Ecological & No & No \\
\hline SNC1D & B2.3 & & $\mathrm{N}$ & $\mathrm{N}$ & Ecological & No & No \\
\hline SNC1D & B2.4 & & $\mathrm{N}$ & $\mathrm{N}$ & Ecological & No & No \\
\hline SNC1D & B2.5 & & $\mathrm{N}$ & $\mathrm{N}$ & Ecological & No & No \\
\hline SNC1D & B3 & & $\mathrm{N}$ & $\mathrm{N}$ & Ecological & No & No \\
\hline SNC1D & B3.2 & & $\mathrm{N}$ & $\mathrm{N}$ & Ecological & No & No \\
\hline SNC1D & B3.5 & & $\mathrm{N}$ & $\mathrm{N}$ & Ecological & No & No \\
\hline SNC1D & C1.2 & $\begin{array}{l}\text { Sample issue: By reducing the accumulation of ice } \\
\text { on roads, road salt makes winter driving safer, } \\
\text { decreasing medical and insurance costs associated } \\
\text { with motor vehicle accidents. But } \\
\text { the compounds in road salt damage roads and } \\
\text { vehicles, pollute water systems, and harm animals } \\
\text { and vegetation. } \\
\text { Sample questions: How has the presence of } \\
\text { mercury in water bodies in Northern Ontario } \\
\text { affected the environment and the lives of } \\
\text { Aboriginal people? How does the widespread use } \\
\text { of agricultural chemicals in Canada or elsewhere } \\
\text { affect the economy, society, and the } \\
\text { environment? What are the economic benefits } \\
\text { and environmental costs of diamond mining for } \\
\text { Northern Canadian communities? }\end{array}$ & 1 & $\mathrm{~N}$ & Ecological & No & No \\
\hline SNC1P & B1 & & $\mathrm{N}$ & $\mathrm{N}$ & Ecological & No & No \\
\hline SNC1P & B1.1 & $\begin{array}{l}\text { Sample issue: Pesticides and fertilizers are used to } \\
\text { increase the productivity of land. However, run-off } \\
\text { flows into water bodies and leaches into } \\
\text { groundwater, poisoning the water or altering its } \\
\text { chemical balance and affecting aquatic } \\
\text { ecosystems. } \\
\text { Sample questions: How does the draining of } \\
\text { wetlands for new subdivisions affect local } \\
\text { waterbirds and plants that thrive in marshes? How } \\
\text { does untreated waste released into rivers or lakes } \\
\text { affect fish and animals that eat the fish? How does } \\
\text { the introduction of Atlantic salmon or other sport } \\
\text { fish affect indigenous lake trout and brook trout? }\end{array}$ & 1 & $\mathrm{~N}$ & Ecological & No & No \\
\hline SNC1P & B1.2 & $\begin{array}{l}\text { Sample issue: Municipal composting initiatives } \\
\text { divert garbage from landfill sites and make com- } \\
\text { post available to gardeners. The use of compost } \\
\text { reduces the need for chemical fertilizers, helping } \\
\text { to ensure the sustainability of aquatic ecosystems } \\
\text { by reducing fertilizer run-off. However, many } \\
\text { people, such as those living in apartment } \\
\text { buildings, are not included in composting } \\
\text { programs. } \\
\text { Sample questions: What action has been taken to } \\
\text { green the grounds of your school? What effect has } \\
\text { such action had on the local ecosystem? What } \\
\text { additional action could be taken? What local } \\
\text { initiatives have been developed to reduce the } \\
\text { amount of pollution released into nearby rivers or } \\
\text { lakes? What additional initiatives could be taken } \\
\text { to enhance the sustainability of these } \\
\text { ecosystems? How has the implementation of an } \\
\text { Environmental Farm Plan (EFP) changed practices } \\
\text { at a local farm? What are the benefits of the plan } \\
\text { with regard to the sustainability of the ecosystem? }\end{array}$ & $\mathrm{D}$ & $\mathrm{D}$ & Ecological & No & No \\
\hline SNC1P & B2 & & $\mathrm{N}$ & $\mathrm{N}$ & Ecological & No & No \\
\hline SNC1P & B2.3 & & $\mathrm{N}$ & $\mathrm{N}$ & Ecological & No & No \\
\hline SNC1P & B2.4 & & $\mathrm{N}$ & $\mathrm{N}$ & Ecological & No & No \\
\hline SNC1P & B2.5 & & $N$ & $\mathrm{~N}$ & Ecological & No & No \\
\hline SNC1P & B3 & & $\mathrm{N}$ & $\mathrm{N}$ & Ecological & No & No \\
\hline
\end{tabular}




\begin{tabular}{|c|c|c|c|c|c|c|c|}
\hline SNC1P & B3.3 & & $\mathrm{N}$ & $\mathrm{N}$ & Ecological & No & No \\
\hline SNC1P & B3.5 & & $\mathrm{N}$ & $\mathrm{N}$ & Ecological & No & No \\
\hline SNC1P & $\mathrm{C} 1.1$ & $\begin{array}{l}\text { Sample issue: Chlorine compounds have strong } \\
\text { disinfectant properties and are used in bleach and } \\
\text { to purify water. However, these compounds can } \\
\text { be highly toxic and must be used with care. } \\
\text { Sample questions: How do the compounds in road } \\
\text { salt reduce ice accumulation? Why are fire } \\
\text { extinguishers that contain compressed carbon } \\
\text { dioxide not suitable for fighting a magnesium fire? } \\
\text { Why do some types of sports equipment use } \\
\text { titanium? Why should gasoline not be used as a } \\
\text { degreasing solvent? }\end{array}$ & $\mathrm{I}$ & $\mathrm{N}$ & Ecological & No & No \\
\hline SNC1P & $\mathrm{C} 1.2$ & $\begin{array}{l}\text { Sample issue: The use of road salt makes winter } \\
\text { driving safer, reducing the social costs of motor } \\
\text { vehicle accidents, including loss of human life. But } \\
\text { the compounds in road salt damage roads and } \\
\text { vehicles, pollute water systems, and harm animals } \\
\text { and vegetation. } \\
\text { Sample questions: What are the social benefits } \\
\text { and environmental costs of mining or refining } \\
\text { metals such as nickel, iron, or gold? What is the } \\
\text { environmental impact of using fertilizers rich in } \\
\text { nitrogen on lawns and gardens? What is the } \\
\text { environmental impact of the widespread use of } \\
\text { plastics? }\end{array}$ & 1 & $\mathrm{~N}$ & Ecological & No & No \\
\hline SNC1P & E2.8 & & $\mathrm{N}$ & $\mathrm{N}$ & Sustainability & Yes & No \\
\hline CHV2O & A1.1 & & $\mathrm{N}$ & $N$ & Politics & No & No \\
\hline CHV2O & $\mathrm{A} 1.2$ & $\begin{array}{l}\text { Sample questions: "If you were advocating for } \\
\text { recreational space for youth in your community, } \\
\text { why would it be important to gather statistics on } \\
\text { the number of people in the local community and } \\
\text { their ages? Are there people you might interview } \\
\text { about the need for such a space?" "Why might } \\
\text { political cartoons be a good source on the ideas of } \\
\text { a political leader and the public response to those } \\
\text { ideas?" }\end{array}$ & $\mathrm{N}$ & $\mathrm{D}$ & Planning & No & No \\
\hline CHV2O & A1.5 & $\begin{array}{l}\text { Sample questions: "What does the term digital } \\
\text { footprint mean? Why is your digital footprint } \\
\text { significant? Do you think that the information you } \\
\text { share on social media with your peers would be } \\
\text { interpreted differently by a potential employer? } \\
\text { Do you think the employer has a right to access or } \\
\text { restrict such information?" "What are the } \\
\text { objectives of the plan of action you are proposing } \\
\text { to address an issue in your school or local } \\
\text { community? What did your investigation reveal } \\
\text { about unintended results of other courses of } \\
\text { action that were implemented to address this } \\
\text { issue?" "What criteria can be used to assess the } \\
\text { changes that have resulted from this decision } \\
\text { taken by a local council?" "How might you } \\
\text { determine whether your student council } \\
\text { represents the perspectives of all students in the } \\
\text { school?" }\end{array}$ & $\mathrm{N}$ & $\mathrm{D}$ & Planning & No & Yes \\
\hline CHV2O & A1.7 & & $\mathrm{N}$ & $\mathrm{N}$ & $\begin{array}{l}\text { Planning, } \\
\text { Sustainability }\end{array}$ & No & Yes \\
\hline CHV2O & B1.1 & $\begin{array}{l}\text { Sample questions: "What are some privacy or } \\
\text { safety issues related to the use of social media? } \\
\text { Do they have an impact on the way you or your } \\
\text { friends use social media?" "What positions are } \\
\text { being voiced in your community with respect to a } \\
\text { local transit issue?" "What are some different } \\
\text { views on the privatization of aspects of the health } \\
\text { care system in Canada?" "What are some } \\
\text { considerations that affect people's consumer } \\
\text { choices? Why might people who favour free trade } \\
\text { and those who favour fair trade differ in the } \\
\text { criteria they use when making these choices?" }\end{array}$ & $\mathrm{D}$ & $\mathrm{D}$ & $\begin{array}{l}\text { Planning, } \\
\text { Tranportation }\end{array}$ & No & No \\
\hline CHV2O & B1.4 & & $\mathrm{N}$ & $N$ & Planning & No & No \\
\hline CHV2O & B2.2 & $\begin{array}{l}\text { Sample questions: "If you were concerned about a } \\
\text { social issue in publicly funded schools, would it be } \\
\text { more appropriate to contact your MP, your MPP, } \\
\text { or your city or band councillor? Why?" "Given his } \\
\text { or her responsibilities, what issues would you like } \\
\text { to discuss with your municipal or band } \\
\text { councillor?" "Why might different levels of } \\
\text { government have different perspectives on the } \\
\text { same issue? In what ways might these diverse } \\
\text { perspectives complicate the policy-making } \\
\text { process? In what ways might they enhance it?" } \\
\text { "What are the main issues in current debates over } \\
\text { Senate reform?" }\end{array}$ & $\mathrm{N}$ & $\mathrm{N}$ & Politics & No & No \\
\hline
\end{tabular}




\begin{tabular}{|c|c|c|c|c|c|c|c|}
\hline $\mathrm{CHV} 2 \mathrm{O}$ & $\mathrm{C} 1.2$ & $\begin{array}{l}\text { Sample questions: "When you brainstormed with } \\
\text { other students, what are some ways you identified } \\
\text { for making a contribution in the community? } \\
\text { Which of these appeal to you? Why?" "Are there } \\
\text { food banks and/or community gardens in your } \\
\text { community? What are some ways in which you } \\
\text { could get involved with them?" }\end{array}$ & $\mathrm{N}$ & $\mathrm{D}$ & Sustainability & No & No \\
\hline $\mathrm{CHV} 2 \mathrm{O}$ & $\mathrm{C} 1.3$ & $\begin{array}{l}\text { Sample questions: "In what ways does using public } \\
\text { transit, biking, or carpooling contribute to the } \\
\text { common good?" "What are some significant } \\
\text { changes in your local community that have been } \\
\text { brought about as a result of citizen action?" } \\
\text { "What impact can consumers' choices have on the } \\
\text { natural environment? }\end{array}$ & $\mathrm{D}$ & 1 & $\begin{array}{l}\text { Systems } \\
\text { (Transportation), } \\
\text { Sustainability }\end{array}$ & No & No \\
\hline $\mathrm{CHV} 2 \mathrm{O}$ & $\mathrm{C} 2.1$ & $\begin{array}{l}\text { Sample questions: "What are some ways in which } \\
\text { various student perspectives are represented in } \\
\text { our school? Do you feel like your voice is heard?" } \\
\text { "What cultural festivals are celebrated in your } \\
\text { community? Whose beliefs and values do they } \\
\text { reflect?" "What religious structures are in your } \\
\text { community? What do they tell you about respect } \\
\text { for diversity in the community?" "Why might } \\
\text { some people's perspectives be valued more than } \\
\text { those of others? What are some ways to address } \\
\text { this inequity? What action could be taken to } \\
\text { ensure that marginalized voices are heard?" }\end{array}$ & $\mathrm{N}$ & $\mathrm{N}$ & Politics & No & No \\
\hline $\mathrm{CHV} 2 \mathrm{O}$ & $\mathrm{C} 2.3$ & $\begin{array}{l}\text { Sample questions: "What are some ways in which } \\
\text { a person can communicate his or her position on } \\
\text { an environmental issue?" "What do you think is } \\
\text { the most effective way for you to get your ideas } \\
\text { heard in our school?" "What criteria might you } \\
\text { use to determine the most effective way to voice } \\
\text { your position on a social justice issue?" }\end{array}$ & $\mathrm{N}$ & 1 & Politics & No & No \\
\hline CHV2O & C3.2 & $\begin{array}{l}\text { Sample questions: "When you consider the } \\
\text { various courses of action proposed to address this } \\
\text { issue, how would you rank them from easiest to } \\
\text { most difficult to carry out?" "Which option do you } \\
\text { think would have the greatest impact?" "Would } \\
\text { you be able to carry out, or participate in, any of } \\
\text { these courses of action?" }\end{array}$ & $\mathrm{N}$ & $\mathrm{N}$ & $\begin{array}{l}\text { Politics, } \\
\text { Sustainability }\end{array}$ & No & No \\
\hline GLC2O & & & $\mathrm{N}$ & $\mathrm{N}$ & Sustainability & No & Yes \\
\hline GLC2O & & & $\mathrm{N}$ & $\mathrm{N}$ & Sustainability & No & Yes \\
\hline SNC2D & D1.1 & $\begin{array}{l}\text { Sample issue: Scientists are researching changes in } \\
\text { climate patterns as possible contributing factors } \\
\text { to an increase in the number of smog days in } \\
\text { Ontario and elsewhere in Canada. As the air } \\
\text { quality worsens, people may curtail their outdoor } \\
\text { activities, and those with respiratory problems } \\
\text { may require medical attention, increasing health } \\
\text { care costs. } \\
\text { Sample questions: How have recent extreme } \\
\text { weather events such as heat waves in Europe or } \\
\text { drought in southern Africa affected habitats in } \\
\text { these regions? How might predicted changes to } \\
\text { global temperature and precipitation affect } \\
\text { agriculture in Ontario, Canada, or different areas } \\
\text { around the world? How might the continuing } \\
\text { reduction of the polar ice cap influence domestic } \\
\text { and international transportation and shipping? }\end{array}$ & $\mathrm{D}$ & $\mathrm{N}$ & $\begin{array}{l}\text { Ecological, } \\
\text { Immigration and } \\
\text { Settlement }\end{array}$ & No & No \\
\hline SNC2D & D1.2 & $\begin{array}{l}\text { Sample issue: Governments and industry have } \\
\text { created rebates or tax cuts to encourage } \\
\text { consumers to replace their old appliances with } \\
\text { efficient ENERGY STAR appliances. However, such } \\
\text { initiatives do not take into account the resources } \\
\text { used to create the new products or the problems } \\
\text { associated with the disposal of old appliances. } \\
\text { Sample questions: What type of recycling and } \\
\text { composting programs are in place in your com- } \\
\text { munity? What proportion of locally generated } \\
\text { garbage do they divert from landfill sites? How } \\
\text { could they be improved? What is the purpose of } \\
\text { carbon offset credits? Do they achieve that } \\
\text { purpose? Why or why not? }\end{array}$ & $\mathrm{N}$ & $\mathrm{D}$ & Politics, Planning & No & No \\
\hline SNC2D & D2.4 & & $\mathrm{N}$ & $\mathrm{N}$ & Ecological & No & No \\
\hline SNC2D & $\mathrm{D} 2.8$ & & $\mathrm{~N}$ & $\mathrm{~N}$ & Climate & No & No \\
\hline SNC2D & D3.4 & & $\mathrm{N}$ & $\mathrm{N}$ & Ecological & No & No \\
\hline
\end{tabular}




\begin{tabular}{|c|c|c|c|c|c|c|c|}
\hline SNC2P & D1.2 & $\begin{array}{l}\text { Sample issue: Motor vehicle emissions are a major } \\
\text { contributor to greenhouse gases. People can } \\
\text { reduce such emissions by walking, biking, or using } \\
\text { public transportation instead of driving; } \\
\text { by keeping their vehicle in good operating } \\
\text { condition; or by driving a hybrid vehicle. } \\
\text { Sample questions: Why do government and/or } \\
\text { industry offer rebates to consumers buying } \\
\text { programmable thermostats and compact } \\
\text { fluorescent light bulbs? How does the production } \\
\text { of oil from the Alberta oil sands contribute to } \\
\text { greenhouse gas emissions? What is the difference } \\
\text { in green- house gas emissions between a } \\
\text { traditional suV and a hybrid vehicle? What is } \\
\text { "clean coal", and what is its impact on greenhouse } \\
\text { gas emissions? How does large-scale livestock } \\
\text { farming increase the production of greenhouse } \\
\text { gases? What ac- tions have you and/or your } \\
\text { community taken to help reduce levels of } \\
\text { greenhouse gases? }\end{array}$ & 1 & D & $\begin{array}{l}\text { Ecological, } \\
\text { Sustainability }\end{array}$ & No & No \\
\hline SVN3E & B1 & & $\mathrm{N}$ & $\mathrm{N}$ & Ecological & No & No \\
\hline SVN3E & B1.1 & $\begin{array}{l}\text { Sample issue: Car emissions contribute to smog as } \\
\text { well as global warming. Road tolls and in- creased } \\
\text { use of public transit to cut down on the number of } \\
\text { cars on the road, and the implementation and } \\
\text { enforcement of idling by-laws, could significantly } \\
\text { cut these emissions. } \\
\text { Sample questions: How can various kinds of } \\
\text { chemical spills in local ecosystems (e.g., fields, } \\
\text { rivers, streams) be cleaned up? In what ways does } \\
\text { improper sewage treatment or agricultural run-off } \\
\text { threaten local water supplies, and how can these } \\
\text { dangers be addressed or averted? What can be } \\
\text { done to minimize the effect of an invasive species } \\
\text { (e.g., purple loosestrife) on a native species (e.g., } \\
\text { milkweed)? }\end{array}$ & $\mathrm{D}$ & $\mathrm{N}$ & $\begin{array}{l}\text { Ecological, } \\
\text { Systems } \\
\text { (Transportation) }\end{array}$ & No & No \\
\hline SVN3E & B1.2 & $\begin{array}{l}\text { Sample issue: Ecotourism attempts to reduce the } \\
\text { waste and environmental damage associated with } \\
\text { mass tourism. Although responsible ecotourism } \\
\text { seeks to conserve local ecosystems through } \\
\text { sustainable practices, and can, for example, help } \\
\text { reduce deforestation and animal poaching rates, } \\
\text { any human intrusion can dam- age fragile } \\
\text { ecosystems. } \\
\text { Sample questions: What are the risks to the } \\
\text { environment of herbicide use and water } \\
\text { consumption on golf courses? What are some of } \\
\text { the risks and benefits to the environment of } \\
\text { landscaping? In what ways can hunters and fishers } \\
\text { damage the environment? In what ways can they } \\
\text { contribute to its sustainability? What rules are } \\
\text { needed to ensure that visitors to a protected area } \\
\text { do not harm that ecosystem? }\end{array}$ & 1 & $\mathrm{~N}$ & Ecological & No & No \\
\hline SVN3E & B2.4 & & $N$ & $\mathrm{~N}$ & Ecological & No & No \\
\hline SVN3E & B3 & & $\mathrm{N}$ & $\mathrm{N}$ & Ecological & No & No \\
\hline SVN3E & B3.1 & & $\mathrm{N}$ & $\mathrm{N}$ & Ecological & No & No \\
\hline SVN3E & B3.5 & & $\mathrm{N}$ & $\mathrm{N}$ & Ecological & No & No \\
\hline SVN3E & B3.6 & & $\mathrm{N}$ & $\mathrm{N}$ & Ecological & No & No \\
\hline SVN3E & B2.2 & & $\mathrm{N}$ & $\mathrm{N}$ & Ecological & Yes & No \\
\hline SVN3E & B2.3 & & $\mathrm{N}$ & $\mathrm{N}$ & Ecological & Yes & No \\
\hline SVN3E & B2.5 & & $\mathrm{N}$ & $\mathrm{N}$ & Ecological & Yes & No \\
\hline SVN3E & $\mathrm{C} 1$ & & $\mathrm{~N}$ & $\mathrm{~N}$ & Ecological & No & No \\
\hline SVN3E & C1.2 & $\begin{array}{l}\text { Sample issue: When the U.S. government } \\
\text { abandoned its Cold War military bases in the } \\
\text { Canadian North, it left behind a variety of } \\
\text { contaminants, including large amounts of } \\
\text { polychlorinated biphenyls (PCBs). Exposure to } \\
\text { these chemicals can affect the nervous system and } \\
\text { the immune system and can cause cancer. } \\
\text { Sample questions: How does the use of biosolids } \\
\text { as fertilizer on Canadian farms affect the health of } \\
\text { local populations? What short- and long-term } \\
\text { health problems can be traced to the chemicals in } \\
\text { the tar ponds in Sydney, Nova Scotia? }\end{array}$ & $\mathrm{N}$ & $N$ & Ecological & No & No \\
\hline SVN3E & $\mathrm{C} 2$ & & $\mathrm{~N}$ & $\mathrm{~N}$ & Ecological & No & No \\
\hline SVN3E & $\mathrm{C} 2.2$ & & $\mathrm{~N}$ & $\mathrm{~N}$ & Ecological & No & No \\
\hline SVN3E & $\mathrm{C} 3$ & & $\mathrm{~N}$ & $\mathrm{~N}$ & Ecological & No & No \\
\hline SVN3E & C3.1 & & $\mathrm{N}$ & $\mathrm{N}$ & Ecological & No & No \\
\hline
\end{tabular}




\begin{tabular}{|c|c|c|c|c|c|c|c|}
\hline SVN3E & D1.1 & $\begin{array}{l}\text { Sample issue: Home energy audit and retrofit } \\
\text { rebate programs have been established by many } \\
\text { provincial governments to help homeowners } \\
\text { reduce their energy bills. Although these programs } \\
\text { raise awareness of the environmental impact of } \\
\text { wasting energy and provide practical ways of } \\
\text { reducing waste, not all homeowners take } \\
\text { advantage of them. } \\
\text { Sample questions: What types of incentives exist } \\
\text { to encourage consumers to purchase energy- } \\
\text { efficient products and services? How effective are } \\
\text { such incentives? What methods do energy } \\
\text { companies use to encourage consumers to } \\
\text { conserve energy? What are some of the non- } \\
\text { governmental organizations in Canada that raise } \\
\text { awareness of the environmental costs of energy } \\
\text { consumption? Are there any groups in your local } \\
\text { community that focus on energy conservation? } \\
\text { How effective are they? }\end{array}$ & $\mathrm{N}$ & D & Politics & No & No \\
\hline SVN3E & D3.3 & & $\mathrm{N}$ & $\mathrm{N}$ & Politics & No & No \\
\hline SVN3E & E2.3 & & $\mathrm{N}$ & $\mathrm{N}$ & Ecological & Yes & No \\
\hline SVN3E & E2.4 & & $\mathrm{N}$ & $\mathrm{N}$ & Ecological & Yes & No \\
\hline
\end{tabular}




\section{Appendix B1: EEW Invitation}

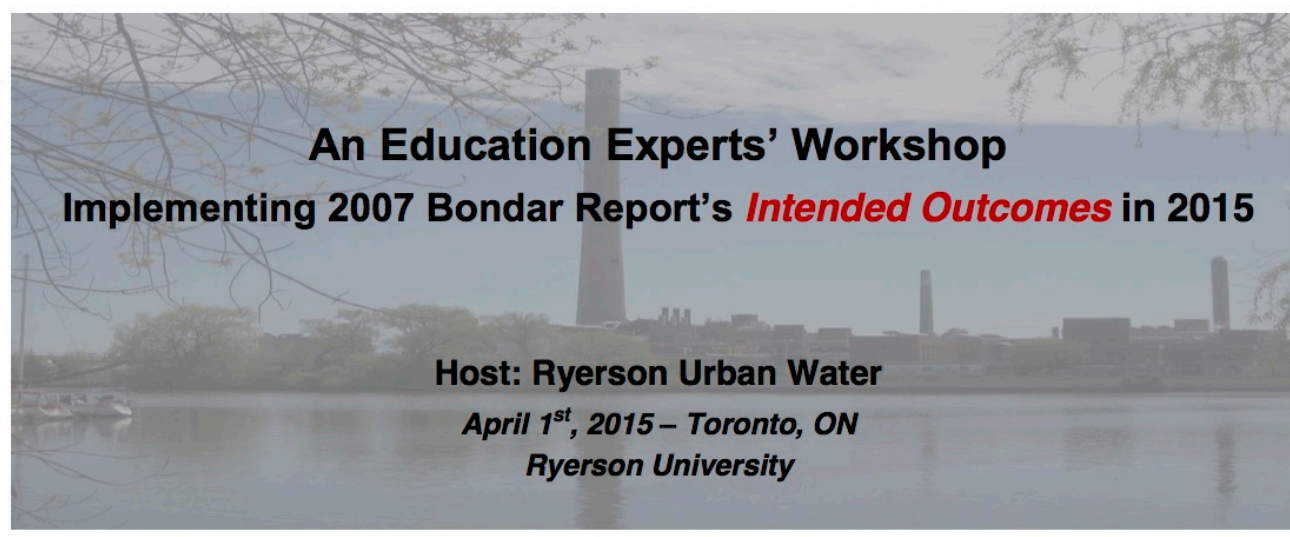

On behalf of Dean Imogen Coe (Faculty of Science) and Ryerson Urban Water (RUW), we invite you to participate in an Education Experts' Workshop on Wednesday, April $1^{\text {st }}, 2015$ at Ryerson University, Toronto. The purpose of the Workshop is to produce a plan to advance environmental education in Ontario schools, with a special emphasis on urban water issues. This will be part of a broader goal in educating the voting citizenry on issues surrounding the development of a healthy urban water cycle.

The 2007 Report of the Working Group on Environmental Education, led by Dr. Roberta Bondar, Shaping Our Schools, Shaping Our Future 1 presented a vision, intended outcomes, and a series of recommendations for an integrated approach to environmental education in Ontario. However, impediments to a comprehensive implementation of the Report's recommendations exist and this Workshop will be the first in a series of dialogues that will examine these challenges and attempt to develop sustainable solutions going forward.

\section{Key components of the workshop}

- Discuss the status of environmental education in Ontario school curricula (K-12).

- Identify existing challenges in the education of Ontario's children in environmental issues.

- Examine the partnerships between the various school boards and community-based environmental organizations (conservation authorities, municipal utilities, foundations and NGOs, outdoor education centres, Ontario Science Centre, Faculties of Education, etc.) and identify existing best practices

- Develop a comprehensive and shared mission to foster the implementation of environmental education in Ontario schools.

- Produce a 10-year "way-forward" blueprint to advance this mission, with measurable outcomes.

Time: $8 \mathrm{am}$ to $4 \mathrm{pm}$. Faculty of Science will cover registration and refreshment costs for all attendees.

Location: Cara Commons ( $7^{\text {th }}$ Floor), Ted Rogers School of Management, 575 Bay St., Toronto, ON

Please RSVP to: L3mccart@ryerson.ca. Should you have any questions, please do not hesitate to contact me at $416-979-5000$ ext. 6378

Regards,

Dr. Lynda McCarthy, Professor

Department of Chemistry and Biology, Ryerson University

\footnotetext{
${ }^{1}$ Working Group on Environmental Education (2007): Shaping Our Future. Environmental Education in Ontario Schools. Available online at: http://www.edu.gov.on.ca/curriculumcouncil/shapingschools.pdf
} 


\section{Appendix B2: EEW Participants List}

Ministry of Education

EEW Participants - confirmed (March 29, 2015)

Cindy Cosentino: Ministry of Education; Education Officer - Science and Innovation

Catherine Mahler: Ministry of Education; Environmental Education

Ministry of Environment, Climate Change

Carolyn O'Neill: Ministry of Environment and Climate Change (MOECC); Manager, Great Lakes

Regional Municipalities

Tracey Carrigan: York Region; Manager, Environmental Education and Promotion

Faculties of Education

Paul Elliott: Trent University, School of Education and Professional Learning

Doug Karrow: Brock University; Science/Environmental Education

Sheila Rhodes: Univ. Ont Institute of Technology (UOIT); School Interdiscipl Studies /Employment Services

Principals

Helen Fisher: Lead Principal, Model School for Inner City Project (MSIC)

David Hawker-Budlovsky: Central Co-ordinating Principal; (Outdoor Education schools); TDSB

Paul Lacalamita: Catholic Principals' Council; Executive Director

William Parish: Principal, Agnes Macphail Public School; (TDSB)

Linda-Sue Thomas: Principal, Ernest Public School; (TDSB)

Teachers

Carly Bardikoff: Ontario EcoSchools; Program Coordinator

Jen Coleman: Orangeville District Secondary School - Upper Grand Board (UGDSB)

Simona Emiliani: MSIC Co-ordinator

Simon Isdell-Carpenter: ACL Gifted Students and School Leadership; William Lyon Mackenzie

C.I.

Jane Lacalamita: Catholic Grade School (retired)

Pam Miller: TDSB, EcoSchools; Instructional Leader

Meg O'Mahoney: University of Toronto Schools (UTS):

Smruti Soni: MSCI; Central Lead Teacher

NGOs/Extracurricular Education Centres/Conservation Authorities

Susan Arndt: Evergreen; Program Director

Lisa Fisk: Evergreen; Project Manager

Chris Hilkene: Clean Water Foundation (CWF); President

Dave Ireland: Royal Ontario Museum (ROM); Biodiversity, Managing Director

Nicole Hamley: Toronto Region Conservation (TRCA); Education Coordinator; Integrated Learning Programs

Amy Lane: Ontario Clean Water Agency (OCWA); Marketing and Corporate Social Responsibility Specialist

Catherine Paisley: Ontario Science Centre (OSC), Vice President; Science Education

Stephanie Sobek-Swant: rare Charitable Research Reserve; Executive Director

Gerrit Kamminga; rare Charitable Research Reserve; Senior Educator

Other Experts

Christine Bata Schmidt, Judi Cohen, Nancy Griffin: IWF (International Women's Forum)

James MacKinnon: Teaching/Learning Services Consultant; Durham Catholic S.B. 
Appendix B3: EEW Draft Agenda

\begin{tabular}{|c|c|c|}
\hline Time & Event & Representative \\
\hline $8: 00$ & $\begin{array}{l}\text { Registration/coffee/muffins } \\
\text { Participants are assigned to tables }\end{array}$ & $\begin{array}{l}\text { Ryerson students / } \\
\text { Kim Gilbride }\end{array}$ \\
\hline $8: 30$ & Welcome & Dean Imogen Coe \\
\hline $8: 35$ & Introduction & Lynda McCarthy \\
\hline $9: 00$ & View from the Ministry of Education & $\begin{array}{l}\text { Catherine Mahler; Cindy } \\
\text { Cosentino }\end{array}$ \\
\hline $9: 30$ & $\begin{array}{l}\text { Fast coffee top-up } \\
\text { Introduction to Round Table discussions }\end{array}$ & Lynda McCarthy \\
\hline $9: 35$ & $\begin{array}{l}\text { Round Table I (RTI): } \\
\text { Defining roles in Environmental Education }\end{array}$ & All participants \\
\hline $10: 15$ & RTI reports (10 min / table) & $\begin{array}{l}\text { Ryerson facilitator for } \\
\text { each table }\end{array}$ \\
\hline $11: 15$ & $\begin{array}{l}\text { Summary of RTI } \\
\text { Participants move to new table organization for } \\
\text { RTII }\end{array}$ & Michal Bardecki \\
\hline $11: 30$ & $\begin{array}{l}\text { Round Table II (RTII): } \\
\text { Looking ahead: Environmental Education for the } \\
\text { future }\end{array}$ & All participants \\
\hline $12: 00$ & Buffet "Working" Lunch & \\
\hline $12: 10$ & $\begin{array}{l}\text { Legacy of Paddle-to-the-Sea: restarting a } \\
\text { conversation with kids regarding the Great Lakes }\end{array}$ & $\begin{array}{l}\text { Andrew Laursen; Vadim } \\
\text { Bostan }\end{array}$ \\
\hline $12: 35$ & Continue RTII discussion & \\
\hline $1: 00$ & RTII reports (10 $\min /$ table) & $\begin{array}{l}\text { Ryerson facilitator for } \\
\text { each table }\end{array}$ \\
\hline $2: 00$ & Leg stretch and networking & $\begin{array}{l}\text { Three-person panel } \\
\text { sequestered to prepare } \\
\text { "Observations of } \\
\text { Workshop" }\end{array}$ \\
\hline $2: 30$ & "Observations of Workshop" & Three-person panel \\
\hline $2: 45$ & Discussion on Workshop & All participants \\
\hline $3: 00$ & "Next steps" & Led by RUW \\
\hline $3: 30$ & $\begin{array}{l}\text { Leg stretch and proceed to RUW Launch to start } \\
\text { at 4:00pm }\end{array}$ & \\
\hline
\end{tabular}




\section{References}

Barratt, R. \& Hacking, E.B. (2011). Place-Based Education and Practice: Observations From the Field. Children, Youth and Environments, 21 (1), 1-13.

Borland, J. (2015). An Historical Geography of Ontario School-Board-Operated Outdoor Education Centres. Ph.D. Philosophy Dissertation, University of Windsor.

Brundtland, G. H., \& World Commission on Environment and Development. (1987). Our common future Oxford University Press.

The Canadian Encyclopedia (2015). Environmental and Conservation Movements. Retrieved November $1^{\text {st }}, 2015$ from http://www.thecanadianencyclopedia.ca/en/article/environmental-andconservation-movements/

Checkoway, B., Richards-Schuster, K., Abdullah, S., Aragon, M., Facio, E., Figueroa, L., Reddy, E., Welsh, M. \& White, A.. (2003). Young People as Competent Citizens. Community Development Journal, 38 (4), 298-309.

Chowdhury, T. R. (2015). The First Step Towards Sustainability: The Practices and Implementation of Environmental Education by Educators in Ontario. MT Research Paper, University of Toronto

Cundiff, B. (1989). Reading, Writing and the Environment. Seasons, 29 (3), 16-19.

Doyle, T.\& MacGregor, S. (2013). Environmental Movements Around the World : Shades of Green in Politics and Culture. Westport, CT: Praeger.

Education Experts' Workshop. (2015). EEW April 2015 Summary v.3. Retrieved May 9 ${ }^{\text {th }}, 2016$ from http://www.ryerson.ca/content/dam/water/education\%20and\%20outreach/ Education\%20Experts\%20Workshop/Recommendations\%20from\%20Education \%20Experts\%20Workshop.pdf

Environmental Education Ontario. (2003). Greening the Way Ontario Learns: A Public Strategic Plan for the Advancement of Environmental Literacy. Retrieved November $1^{\text {st }}$, 2015 from http://www.eeon.org/greening-the-way-ontario-learns/ 
Forests Ontario. (2016). Ontario Envirothon. Retrieved March 3rd, 2016 from http://www.forestsontario.ca/education/programs/ontario-envirothon/

Godfrey, B. J. (2010). Urban Sustainability: Teaching at the Interface of Environmental and Urban Studies. Ometeca, 274.

Gruenewald, D. A. (2003). The Best of Both Worlds: A Critical Pedagogy of Place. Educational Researcher, 32 (4), 3-12.

Henderson, A., Brown, S.D., Pancer, M., \& Ellis-Hale, K. (2007). Mandated Community Service in High School and Subsequent Civic Engagement: The Case of the "Double Cohort" in Ontario, Canada. Journal of Youth and Adolescence, 36 (7), 849-860.

Hsieh, H. \& Shannon, S.E. (2005). Three Approaches to Qualitative Content Analysis. Qualitative Health Research, 15 (9), 1277-1288.

Igbokwe, A.B. (2012). Environmental Literacy Assessment: Exploring the Potential for the Assessment of Environmental Education/Programs in Ontario Schools. International Journal for Cross-Disciplinary Subjects in Education, 3 (1), 648-656.

International Union for the Conservation of Nature and Natural Resources. (1970). International Working Meeting on Environmental Education in the School Curriculum, Paris: UNESCO.

Kopar, C. (2013). The Characteristics of Effective Environmental Education Programs: An exploration of the perceptions of environmental educators in Southern Ontario. M.E.S. Thesis, University of Waterloo.

Louv, R. (2008). Last Child in the Woods: Saving Our Children From Nature-Deficit Disorder. New York, NY: Algonquin Books.

Lowenstein, E., Martusewicz, R., \& Voelker, L. (2010). Developing Teachers' Capacity for EcoJustice Education and Community-Based Learning. Teacher Education Quarterly, 37 (4). 
Mannion, G. \& Adey, C. (2011). Place-Based Education Is an Intergenerational Practice. Children, Youth and Environment, 21 (1), 35-58.

Neal, P. (1994). Handbook of Environmental Education. New York, NY: Routledge

North American Association for Environmental Education. (2015). Urban Environmental Education. Retrieved August 10, 2015 from http://www.naaee.net/sites/default/files/eecapacity/UEE2015.pdf

Ontario EcoSchools (2016). Ontario EcoSchools. Retrieved March 3rd, 2016 from http://www.ontarioecoschools.org

Ontario Institute for Studies In Education (2013). Deepening Environmental Education in Pre-Service Education Resource. Retrieved August 12, 2015 from http://www.oise.utoronto.ca/ese/UserFiles/File/DEEPER\%20Guide\%202014.pdf

Ontario Ministry of Education (2007a). Ready, Set, Green! Tips, Techniques and Resources from Ontario Educators. Retrieved February 7, 2016 from https://www.edu.gov.on.ca/eng/document/policy/readySetGreen.pdf

Ontario Ministry of Education (2007b). Shaping Our Schools, Shaping Our Future: Environmental Education in Ontario Schools. Retrieved August 10, 2015 from http://www.edu.gov.on.ca/eng/teachers/enviroed/shapingSchools.html

Ontario Ministry of Education. (2008). Standards for Environmental Education in the Curriculum. Retrieved February 8, 2016 from http://www.edu.gov.on.ca/eng/teachers/enviroed/Env_Ed_Standards.pdf

Ontario Ministry of Education. (2009). Acting Today, Shaping Tomorrow: A Policy Framework for Environmental Education in Ontario Schools. Retrieved August 10, 2015 from http://www.edu.gov.on.ca/eng/teachers/enviroed/action.html

Ontario Ministry of Education. (2011). Environmental Education: Scope and Sequence of Expectations. Retrieved August 20, 2014 from http://www.edu.gov.on.ca/eng/curriculum/secondary/environment.html 
Ontario Ministry of Education. (2014). The Ontario Curriculum - Secondary. Retrieved July 31, 2014 from http://www.edu.gov.on.ca/eng/curriculum/secondary/index.html

Ontario Ministry of Municipal Affairs and Housing. (2005). Places to Grow: Better Choices, Brighter Future. Retrieved November 3, 2014 from https://www.placestogrow.ca/index.php?option=com_content\&task=view\&id=9\&lt emid $=14$

Ontario School Information System. (2013). Education Facts, 2012-2013. Retrieved September 7, 2015 from http://www.edu.gov.on.ca/eng/educationFacts.html

Pardy, B. (2010). Ontario's Policy Framework for Environmental Education: Indoctrination and Integration. Pathways: The Ontario Journal of Outdoor Education, 22 (2), 22-23.

Palmer, J. (1993). Development of Concern for the Environment and Formative Experiences of Educators. The Journal of Environmental Education. 24 (3), 26-30.

Palmer, J. (1998). Environmental Education in the 21st Century: Theory, Practice, Progress and Promise. New York, NY: Routledge.

Pedretti, E., Nazir, J., Tan, M., Bellomo, K., \& Ayyavoo, G. (2012). A Baseline Study of Ontario Teachers' Views of Environmental and Outdoor Education. Pathways: The Ontario Journal of Outdoor Education, 24 (2), 4-12.

Puk, T. \& Behm, D. (2003). The Diluted Curriculum: The Role of Government in Developing Ecological Literacy as the First Imperative in Ontario Secondary Schools. Canadian Journal of Environmental Education, 8, 217-232.

Puk, T. \& Makin, D. (2006). Ecological Consciousness in Ontario Elementary Schools: The Truant Curriculum and the Consequences. Applied Environmental Education \& Communication, 5 (4), 269-276.

Reimers, F. (2006). Citizenship, Identity And Education: Examining The Public Purposes Of Schools In An Age Of Globalization. Prospects, 36 (3), 275-294.

Sanders, M.G. (2003). Community Involvement In Schools - From Concept to Practice. Education and Urban Society, 35 (2), 161-180. 
Smith, G.A. (2007). Place-Based Education: Breaking Through the Constraining Regularities of Public School. Environmental Education Research, 13 (2), 189-207.

Stapp, W.B. (1969). The Concept of Environmental Education. Environmental Education, 1 (1), 30-31.

Statistics Canada, (2011), 2011 Census of Population, Retrieved November 6, 2015 from http://www12.statcan.gc.ca/census-recensement/2011/as-sa/index-eng.cfm

Steele, A. (2011). Beyond Contradiction: Exploring the Work of Secondary Science Teachers as They Embed Environmental Education in Curricula. International Journal of Environmental and Science Education, 6 (1), 1-22.

Stevenson, R. B. (2007). Schooling and Environmental Education: Contradictions in Purpose and Practice. Environmental Education Research, 13 (2), 139-153.

Stevenson, R.B., Brody, M., \& Dillon, J. (2012). International Handbook of Research on Environmental Education. Florence, KY: Routledge.

Tan, M. \& Pedretti, E. (2010). Negotiating the Complexities of Environmental Education: A Study of Ontario Teachers. Canadian Journal of Science, Mathematics and Technology Education, 10 (1), 61-78.

Tanner, M. (1997). The Evolution of Environmental Management in Canada. The London Journal of Canadian Studies, 13, 1-11.

Toronto District School Board (2011). Model Schools for Inner Cities. Retrieved March 10th, 2016 from http://www.tdsb.on.ca/Community/ModelSchoolsforInnerCities.aspx

Turner, W. R., Nakamura, T., \& Dinetti, M. (2004). Global Urbanization and the Separation of Humans from Nature. Bioscience, 54 (6), 585-590.

UNESCO. (1975). The International Workshop on Environmental Education, Belgrade, Yugoslavia. Retrieved on November $1^{\text {st }}, 2015$ from http://unesdoc.unesco.org/images/0002/000276/027608EB.pdf 
UNESCO. (1978). Final Report: Intergovernmental Conference on Environmental Education. Organized by UNESCO in Cooperation with UNEP, Tbilisi, USSR. Retrieved on November $1^{\text {st }}, 2015$ from http://unesdoc.unesco.org/images/0003/000327/032763eo.pdf

UNESCO. (1992). United Nations Conference on Environment \& Development Rio de Janerio, Brazil, 3 to 14 June 1992 - Agenda 21. Retrieved on February $21^{\text {st }}, 2016$ from https://sustainabledevelopment.un.org/content/documents/Agenda21.pdf

UNESCO. (2005). UNESCO and Sustainable Development, Paris, France. Retrieved on February $20^{\text {th }}, 2016$ from http://unesdoc.unesco.org/images/0013/001393/139369e.pdf

Vancouver Working Group. (2006). The Youth Friendly City - Prepared for 2006 United Nations World Urban Forum. Retrieved July 29, 2014 from http://www.cscd.gov.bc.ca/lgd/intergov_relations/library/wuf_the_youth_friendly_c ity.pdf

Woodhouse, J. L. \& Knapp, C. (2000). Place-based curriculum and instruction: Outdoor and environmental education approaches. Charleston, WV: ERIC Clearinghouse on Rural Education and Small Schools.

World Health Organization. (2015). Programmes - Global Health Observatory (GHO) - Urban Population Growth. Retrieved July 30, 2014 from http://www.who.int/gho/urban_health/situation_trends/urban_population_growth_t ext/en/ 